UNIVERSIDADE DE SÃO PAULO

INSTITUTO DE PSICOLOGIA

DEPARTAMENTO DE PSICOLOGIA EXPERIMENTAL

Sobre um conceito integral de empatia:

intercâmbios entre filosofia, psicanálise e neuropsicologia

Adriana De Simone 
Sobre um conceito integral de empatia:

intercâmbios entre filosofia, psicanálise e neuropsicologia.

\section{Adriana De Simone}

Tese apresentada ao Instituto de Psicologia da Universidade de São Paulo como parte dos requisitos para obtenção do título de Doutor(a) em Psicologia

Área de Concentração: Psicologia Experimental

Orientador: Prof. Dr. Klaus Tiedmann 


\section{AUTORIZO A REPRODUÇÃO E DIVULGAÇÃO TOTAL OU PARCIAL DESTE TRABALHO, POR QUALQUER MEIO CONVENCIONAL OU ELETRÔNICO, PARA FINS DE ESTUDO E PESQUISA, DESDE QUE CITADA A FONTE.}

Catalogação na publicação

Biblioteca Dante Moreira Leite

Instituto de Psicologia da Universidade de São Paulo

De Simone, Adriana.

Sobre um conceito integral de empatia: intercâmbios entre filosofia, psicanálise e neuropsicologia / Adriana De Simone; orientador Klaus Tiedmann. -- São Paulo, 2010.

$178 \mathrm{f}$.

Tese (Doutorado - Programa de Pós-Graduação em Psicologia. Área de Concentração: Psicologia Experimental) - Instituto de Psicologia da Universidade de São Paulo.

1. Empatia 2. Intersubjetividade 3. Identificação projetiva 4. Neuropsicanálise 5. Espelhamento I. Título.

BF575.E55 


\section{SUMÁRIO}

\section{Capítulo I - Introdução, 08}

I.1. Definição das palavras "empatia" e "simpatia", 09

I. 2. 0 conceito de empatia no séc XIX e início do séc XX, 13

I. 3. Relevância do tema, 16

\section{Capítulo II - A produção de conhecimento, 21}

II. 1. A produção de conhecimento na psicanálise: subjetivismo e verdade, 21

II.1.1. Verdade em Freud, 22

II.1.2. Influência de Kant na psicanálise, 26

II.1.3. Nova(s) psicanálise(s), 27

II. 2. A produção de conhecimento na fenomenologia, 38

II.2.1. Maurice Merleau-Ponty, 41

II.2.2. Emmanuel Levinas e Platão, 45

II. 3. A produção de conhecimento na neurociência, 49

II.3.1. Introducão `a Neuropsicologia moderna: conceito de sistema, 49

II.3.2. Uma breve consideração sobre o uso das técnicas de neuroimagem, 53

II.3.4. Neuropsicologia da emoção, 55

II.3.4.1. 0 papel das emoções, 55

II.3.4.2. Estudos empíricos sobre empatia, 57 
II. 4. Psicanálise e Neurociência : Neuropsicanálise, 60

\section{Capítulo III - Empatia, 77}

III.1. Empatia na psicanálise, 77

III.1.1. Conceito metapsicológico de Eu (Freud), 80

III.1.2. Sobre o conceito de objeto, 82

III.1.3. Self em Melanie Klein, 84

III.1.4. Posição esquizo-paranóide e posição depressiva, 85

III.1.5. Identificação Projetiva, 88

III.1.5.1 Desenvolvimento do conceito de identificação projetiva, 90

III.1.6. Donald W. Winnicott: mãe 'empática’ propicia verdadeiro self, 96

III.1.7. O papel do negativo na constituição do self e a relação de objetos, 103

III.1.8. Psicologia do ego e self psychology, 105

III.1.9. Algumas diferenças nas formulações dos teóricos pós-freudianos, 107

III.1.10. Imagem corporal, 110

III.2. Empatia na Fenomenologia, 113

III.2.1. Edith Stein, 116

III.2.2. Emmanuel Levinas, 117

III.2.3. Breve exposicão da Hermenêutica em Dilthey, 118

III.3. Empatia na neuropsicologia, 120

III.3.1. Teoria da mente e o senso de si-mesmo, 120

III.3.2. Teoria da mente e fMRI, 123 
III.3.3. Neuron system, 125

III.3.4. Empatia como afeto e emoção, 127

III.4. Empatia na Neuropsicanalise, 132

III.4.1. Descobertas de Allan Shore, 135

III.4.2. Transtorno Borderline de Personalidade, 138

III.4.2. Autismo, 144

III.4 Empatia e Bem, 144

IV. Capítulo - Discussão, 147

IV.1. Sobre o Self, 158

IV.1.2. Política e o desejável, 165

Referências, 168 


\section{AGRADECIMENTO}

Este trabalho tem um percurso longo, que se estende por compridos anos. Porém, desde minha formação como psicóloga (PUC-SP, 1998) considero uma grande oportunidade ter tido a possibilidade de trabalhar com linguagens e distintos ambientes de pesquisa. Venho estabelecendo um diálogo entre a psicanálise e as neurociências, pautada pela experiência de duração de 6 anos, com pesquisa em ressonância magnética funcional, simultânea ao trabalho na clínica psicanalítica. Nos últimos anos, me voltei para a atividade com as artes, especialmente usando a técnica de aquarela. A experiência me levou a questionar campos antes desconsiderados, como o criativo, a fruição do Belo, e questões do Ser.

Agradeço ao prof. Klaus Tiedmann por ter me recebido em um momento crítico e pelas sugestões e paciência.

Agradeço aos meus pais, sem os quais esse trabalho não teria sido possível.

A todos os que estiveram do meu lado. Aos que me tornaram mais forte.

Agradeço por sobre os todos, ao meu Deus. 
(...) "toda soberba tende, por sua essência a igualar-se com Deus, a fazer-se Deus. Desordem esta por extremo grande, e que hesitaríamos a crer possível, se não tivessemos sempre presente a nossos olhos, e se lhe não sentíssemos o germe em nós mesmos. Não esqueçamos nunca a queda fatal de Lúcifer, a quem disse o Eterno pela boca de Isaías: "Como caíste, tu que te levantavas como estrela da manhã, que dizias em teu coração: Subirei ao mais alto dos céus, estabelecerei meu trono acima das estrelas, e serei semelhante ao Altíssimo? Eis que serás precipitado nos infernos, na profundeza do abismo" (Is 14,12,16)!

Lede no evangelho, as tremendas ameaças pronunciadas pelo Salvador contra os fariseus soberbos, enquanto os pecadores saem perdoados de sua presença. Madalena prostra-se aos pés de Jesus, humilha-se de suas culpas, nem se atreve a pedir perdão delas, em silêncio ora e suplica.

Comovido o Salvador de sua humildade, consola sua dor dizendo aos seus discípulos: "Muitos pecados lhe são perdoados porque me amou muito."” in: Imitação de Cristo, abade Tomás de Kempis, 1441j 


\section{Resumo}

De Simone, A. Sobre um conceito integral de empatia: intercâmbios entre filosofia, psicanálise e neuropsicologia. Tese - Instituto de Psicologia da Universidade de São Paulo Departamento de Psicologia Experimental, São Paulo, 178 pg, 2010.

Este trabalho faz uma revisão das principais teorias em psicanálise, fenomenologia, e neurociência na tentativa desenvolver um conceito integral de empatia. Em Freud empatia depende da identificação e dos laços emocionais que decorrem da pulsão de vida; em Klein se apresenta como identificação projetiva benéfica; em Bion relaciona-se aos vínculos (L, K, $\mathrm{H})$, o Outro é transcendência ("O"); em Winnicott traduz-se em holding e propicia o surgimento do verdadeiro self; na neurociência cognitiva depende de inferências cognitivas (teorias sobre "teoria da mente"), e de imitação implícita (Gallese); na neuropsicologia da emoção depende de um componente emocional básico, ou das emoções primárias; na neuropsicanálise relaciona-se com a maturação do hemisfério direito (Allan Shore) e `a identificação projetiva; na fenomenologia de Husserl empatia está relacionada `a intersubjetividade (o outro é outro-eu); em Heidegger é a própria abertura do ser-aí, ou compreensão; Levinas o rosto significa outramente, pressupõe a relação de responsabilidade e a superação do Mesmo. Relaciona-se ainda com bondade e amor.

Pautados nos conceitos destes autores, consideramos que a empatia pertence a duas qualidades de experiência: (1) contágio emocional ou ressonância de afeto pela qual o euoutro perdem suas fronteiras definidas; que não acompanha a idéia do Outro como alteridade (emoções primárias, comunicação inconsciente de afeto, identificação projetiva, compreensão originária do ser-no-mundo) e, (2) identificação que decorre da imagem/representação do corpo por espelhamento e mimetismo. Nosso conceito integral, portanto, considera o psiquismo como uma estrutura psíquica enquadrante (Green) e vazia a ser preenchida pelo cuidado e bons objetos primordiais. A empatia ou comunhão afetiva decorre da pré-concepção (Bion) ou de uma abertura originária do ser, de caráter inato e filogenético, de responsabilidade para com o outro como outro-eu, que é, também, diferente. Em termos neuroanátomo-funcionais se identificam dois sistemas sobrepostos que tem seus epicentros no hemisfério direito sendo o primeiro epicentro o córtex órbitofrontal (relacionado ao sentimento de si-mesmo); e, o segundo, a área somatosensorial (formador da auto-imagem) e suas aferências-eferências, provindos de àreas motoras e de linguagem (Broca). A empatia (do grego empatheia) pode ser descrita, portanto como duas formas básicas de funcionamento, que nos remete `a sua relação léxica com a palavra grega sympátheia como fator unificador (Plotino). As traduções adequadas a ambos os termos seria "sentir-com" (Mitfühlung) e "sentir-dentro" (Einfühlung).

PALAVRAS-CHAVE: Einfühlung; empatia; intersubjetividade; identificação; mirror-system; Mitfühlung; neuropsicanálise; neuropsicologia; ressonância afetiva 


\section{Introdução}

Esta pesquisa investiga o que permite que alguns sejam afetados pelo outro, sintam compaixão pela miséria alheia, se emocionem com uma obra de arte ou com a natureza, enquanto outros não. A premissa básica é de que há uma abertura de qualidade afetiva para o mundo, que constitui uma forma de sensibilidade ou percepção sensível, relacionada a um sentido de si-mesmo. De outra forma, a relação com o outro se dá em um campo no qual a emoções e afetos se misturam, e nesse sentido, nosso interesse parte do que a experiência mostra ser a "escuta do coração". Este seria o fundamento de um 'sentido para o outro', e se contrapõe claramente ao funcionamento da mente orientada por uma escolha narcísica de objeto. Como premissa, esta sensibilidade difere da mente que automaticamente detecta relações causa-efeito com um fim determinado, valorizada no séc XXI, da qual nasce a objetificação mecânica do mundo e do homem individualista, e a competição "cega”.

Dentre os méritos de um trabalho que considere a empatia, se destaca a psicanálise. A análise, deveria abrir espaço para que o próprio sujeito se aproprie do que está sob investigação: ele mesmo. Permite que se revele o 'si-mesmo', ou o 'gesto espontâneo', em um campo de significação do próprio indivíduo. Em uma vertente bioniana a análise promove "transformações", busca a erupção de um novo padrão de experiência, como a substituição da onipotência pela humildade.

Uma boa delimitação do termo "empatia" na psicologia abarcaria também o fenômeno acima descrito, ou a substituição da visão de homem-máquina por um homem afetivo e dependente do ambiente (o outro em suas mútiplas aparições). Escolhemos, portanto, a investigação deste conceito que recebe significações diversas em cada campo de 
conhecimento, e é fundamental na obra de alguns autores da filosofia, psicanálise e também em pesquisas atuais de neurociência.

\section{I.1. Definição das palavras "empatia" e "simpatia"}

A palavra empatia, provém do inglês (empathy) traduzido, como veremos, do termo psicológico alemão Einfühlung. O substantivo empathy é definido como: 1. projeção imaginativa de um estado subjetivo em um objeto que no caso aparece pervadido por ele 2 . a ação de entendimento, estar consciente de, estar sensível a, e experienciar sentimentos de outrem, tanto no passado como no presente, sem que os sentimentos, pensamentos e experiência tenham sido plenamente comunicados de maneira objetivamente explícita; ainda a capacidade para isso (Merriam-Webster's Collegiate Dictionary, 2003).

Na lingua portuguesa empatia é definida como: (1) a faculdade de compreender emocionalmente um objeto; (2) capacidade de projetar a personalidade de alguém num objeto, de forma que este pareça como que impregnado dela; (3) capacidade de se identificar com outra pessoa, de sentir o que ela sente, de querer o que ela quer, de apreender do modo como ela apreende; (3.1.) PSIC. Processo de identificação no qual o sujeito se coloca no lugar do outro e, com base em suas próprias suposições ou impressões, tenta compreender o comportamento do outro; (3.2.) SOC. forma de cognição do eu social mediante três aptidões: para se ver do ponto de vista de outrem, para ver os outros do ponto de vista de outrem ou para ver os outros do ponto de vista deles mesmos. (Hoaiss, 2006)

A raiz etimológica de empatia é a denominação grega empatheia, que provém de empathēs, em- (colocar dentro, em) + páthos (paixão). A raíz páthos (paixão) veicula a idéia geral de sofrer, sentir, suportar e padecer, dentre outros significados, como excesso e assujeitamento. Da família etimológica de páthos, surgem as palavras gregas sympátheia, 
apátheya, empátheia, pathetikós (Merriam-Webster's Collegiate Dictionary, 2003).

A palavra alemã Einfühlung com suas raízes ein (dentro) e fühlen (sentir) não é adequadamente traduzida para o português como "sentir com", que corresponde `a tradução da palavra "simpatia" (Mitfühlung). Porém, encontra-se na literatura psicanalítica o uso do termo "empatia" (Einfühlung) segundo o que seria (Mitfühlung).

Vale a pena citarmos o artigo de Pimentel e Coelho Jr (2009) sobre o trabalho de Ferenczi: “Segundo alguns autores, Ferenczi (...), postula a noção de tato psicológico como norteadora da ação do analista. Tato psicológico é definido como "a faculdade de 'sentir com' (Einfühlung)", como o estabelecimento de um contato empático que tem a função de possibilitar uma compreensão emocional de "quando e como se comunica alguma coisa ao analisando" (Ferenczi, 1928, In: Pimentel e Coelho, 2009, p.306). Ao usar o tato como guia durante as sessões, Ferenczi introduz um novo ingrediente à técnica analítica: a empatia." (Chertok e Stengers, 1990 In: Pimentel e Coelho Jr, 2009, p.306) Também se encontra a equivalência entre os termos "empatia" e "simpatia", tratados como virtudes relacionadas `a generosidade, em trabalhos sobre a gênese da moralidade na criança. Como afirma La Taille (2006), "é o caso dos trabalhos sobre ética do cuidado, sobre condutas pró-sociais e sobre simpatia (ou empatia)." (La Taille, 2006, p. 10)

Na antiguidade, Plotino (séc.III) usa a palavra sympátheia em diferentes contextos. 0 neoplatonismo elaborado por ele exerceu forte influência sobre o pensamento medieval. Nas Enéadas, Plotino usa a palavra sympátheia como fator unificador `a imagem da emanação solar (que permite a contemplação) e do papel afetivo do Sol. Na sua doutrina da simpatia cósmica o kosmos é um organismo (zoon) vivo em que todas as partes estão impregnadas da alma universal. O Cosmos é uma espécie de animal, um e múltiplo, em simpatia consigo mesmo; suas partes similares, ainda quando não estão próximas, vibram juntas como as cordas de uma lira, de forma que uma parte ressoa em outras, pela simpatia. 
A noção de sympátheia serve também para explicar a influência que os corpos celestiais exercem. Os planetas, e seus vários movimentos, têm efeitos sobre as coisas. De acordo com Plotino, no estoicismo, podemos apenas encontrar simpatia na estrutura de um organismo. Plotino, todavia, coerente com os seus pontos de vista sobre a sympátheia, nega a necessidade de um médium de sensação, a transcendência de Deus é preservada pois a sua providência pode ser exercida indiretamente através da inter-relação das coisas. Explica pela sympátheia a eficácia de mágicas (uso de poderes simpatéticos das coisas) e das orações, que não são de natureza sobrenatural. A adivinhação (mantike) e leituras prognósticas de adivinhação astrológica também dependem da sympátheia. 0 sábio que, em vez disso, se dedica à contemplação, está bem acima do uso de poderes simpatéticos. A natureza contempla e produz porque contempla, e toda a produção, em qualquer nível de realidade, é determinada pela contemplação. A natureza efetua um ato contemplativo ao produzir o universo sensível. (Plotino, 2008; Zamora, 2003)

A palavra simpatia, portanto, provém do grego sympátheia, sendo formada pelo prefixo syn- (com, co-, junto, sintético) e o substantivo páthos. No inglês sympathy é definida como: 1.a. uma afinidade, associação, ou relacionamento entre pessoas ou coisas de forma que aquilo que afeta um similarmente afeta o outro; 1.b. suscetibilidade mútua ou paralela ou a condição pela qual isso ocorre; 1.c. unidade ou harmonia na ação e no efeito; 2.a. inclinação para o pensar ou sentir semelhante; 2.b. sentimento de fidelidade; 3.a. o ato ou a capacidade para adentrar ou compartilhar sentimentos ou interesses do outro; 3.b. o sentimento ou estado mental gerado por esta sensibilidade; 3.c. a correlação existente entre corpos capazes de comunicar sua energia vibracional por algum meio (sinônimo: atração) (Merriam-Webster's Collegiate Dictionary, 2003).

Dentre outros filósofos gregos, devemos mencionar Aristóteles (384-322 A.C.) (Ética à Nicômaco), formador da cultura ocidental. A simpatia relaciona-se com a filantropia como 
"afecção pela humanidade" e é a manifestação natural pelos membros de sua própria espécie, presente em quase todos os animais. Desde que somos amantes do ser enquanto ser, aquilo que se assemelha ao ser nos afeta; os homens são afetados por eles mesmos mais ou menos, pois estas relações pertencem, mais do que tudo ao próprio ser.

A simpatia, como habilidade para "sofrer com o outro", tem aparição na lingua latina entre 1560-70 (sympathīa), ou final do séc. XVI e marca um fato importante, o nascimento de uma nova sensibilidade artística junto com a noção de "compaixão poética" de Aristóteles (HaCohen, 2001). Um conceito múltiplo de simpatia também foi feito pelo fenomenólogo Max Scheler (1874-1928) (Natureza e formas da simpatia, 1923).

Como vemos, as definições da palavra empatia se aproximam do que define o termo simpatia. Porém, a empatia depende de mecanismos como: projeção imaginativa, ação de entendimento, capacidade de entendimento, capacidade de projetar, processo de identificação, forma de cognição. Enquanto a simpatia envolve: afinidade, harmonia na ação e no efeito, inclinação para o pensar ou sentir semelhante, suscetibilidade mútua, compartilhar sentimentos ou interesses do outro, ou, ainda comunicar sua energia vibracional, como na atração física dos corpos.

Apesar de ambas as palavras serem da família da raíz grega páthos, diferenças de acepção podem ser melhor captadas se analisarmos os prefixos gregos syn- (com, co-, junto, sintético) e em- (colocar dentro, em). Co- pathos (sofrimento, padecimento, sensação) não delega "mecanismos" de sua ocorrência, apesar de incluir a capacidade de ser afetado pelo outro. Sentir-com é um compartilhar, uma espécie de relacionamento eu-outro no qual há uma similaridade imediata de sentimentos compartilhados. Abarca de forma sintética o que seria um co-padecimento, co-sentimento, co-sensação, e aproxima-se do que entendemos por compaixão. O sentir-em, por outro lado, implica em algum reconhecimento do eu e outro e de algum mecanismo, no qual o lugar "em mim" recebe algo de fora. Há uma 
separação que no sentir-em não se explicita.

Definir empatia, portanto depende da definição de termos psicológicos como “mecanismos de projeção" ou "processo de identificação" relativo ao pathos (sofrimento, padecimento, sensação) experimentado na relação Eu-Outro.

A simpatia, ou sentir-com, por sua vez, descrita como o compatilhar de emoções, descreve a experiência enquanto domínio do todo possível na expressão dela mesma, por exemplo no riso ou no silêncio. 0 silêncio compartilhado exprime a penetração em esferas sensoriais que as palavras apenas encobrem.

O conceito de empatia desenvolvido neste trabalho inclui as formas de simpatia, pois, como veremos, na psicologia os dois conceitos não foram discriminados quando Theodor Lipps "traduziu" um conceito de simpatia de David Hume, com algumas inovações especialmente quanto `a "imitação implícita”, como Einfühlung (no inglês, empathy).

\section{I.2. O conceito de empatia no séc XIX e início do séc XX}

No final do séc XIX, filósofos alemães da Einfühlung estavam preocupados com a relação entre estética e o sentido espacial do self (Etlin, 1998). Estes filósofos, muitos dos quais eram historiadores da arte, foram precedidos por Georg Sulzer (General Theory of the Fine Arts; 1771-1774) que traduziu o termo do grego aisthetikos; aistheta; (estética) segundo sua etiologia, como ciência dos sentimentos (empfindungen) e instrumento para a compreensão da verdadeira natureza da alma. Se engajaram no que denominaram como estética (Kunstwissenschaft, ing.: aesthetics) (Collins German Dictionary, 2004), ou princípio científico subjacente `a estética, considerados aspectos os sencientes (Gefühl; ing.:feeling, sensation, sense; port.: sentido, sentimento). Empregaram diversos termos para enfatizar o sentido vital como oposto `as sensações, como Lebensgefühl (sentimento de ser/estar vivo) ou Vitalgefühl (sensibilidade ou sensação vital). Para descrever o aspecto senciente que 
implica no sentimento que permeia o corpo eles invocaram o termo Korpegefühl (korper: mente; gefühl: sentido, sentimento). A ênfase no sentimento do espaço como o sentido do corpo circundado por um espaço arquitetônico ou o sentimento do espaço no qual o self corporal é o centro, foi denominado Raumgefühl. A resposta estética para a qualidade de linhas ou massas em formas artisticas naturais foi denominada Formgefühl (ing.: sense of form; port.: sentido de forma).

Finalmente, o termo Einfühlung explicava o impulso por trás de mudanças de estilo, de uma era cultural para outra, sendo as propriedades que respondiam a isso denominadas sencientes. Einfühlung também denominada no campo estético como "teoria da empatia", teve grande influência na arquitetura, ao enfatizar o papel do corpo e sua predisposição cinestética (kinesthetic) sobre os processos de percepção e cognição. (Aguiar, 2006)

A citação seguinte de Sulzer apresenta como esta escola descreveu o sentimento evocado por uma obra de arte: "a alma se torna em essência, toda sentimento" e "sabe nada do exterior, mas apenas do que está dentro do si-mesmo". (in Etlin, 1998, p.01)

Dentre os filósofos alemães do final do séc XIX, Robert Vischer contribuiu para ampliação do conceito de Einfühlung na sua tese de doutorado, On the Optical Sense of Form: A Contribution to Aesthetics-1873. Em seu trabalho Einfühlung foi usado para descrever a experiência do self frente a objetos inanimados, na arquitetura, natureza e arte.

Posteriormente, o filósofo alemão Theodor Lipps (1851-1914), foi influenciado pela filosofia moral e empírica de David Hume (1711-1776) (A treatise of Human Nature, 173940) na qual a simpatia (Mitfühlung) é considerada uma propensão primária da natureza humana. Hume descreve a tendência para receber as inclinações ou sentimentos dos outros por meio da comunicação, e demonstra a importância central da simpatia na vida moral, correspondente `a importância dada `as crenças na esfera do entendimento. Hume afirma: 
"nenhuma qualidade da natureza é mais notável em si mesma e em suas consequências do que a propensão que temos de simpatizar com outros e para receber, pela propensão `a comunicação, suas inclinações, ainda que `as vezes sejam diferentes ou mesmo contrárias

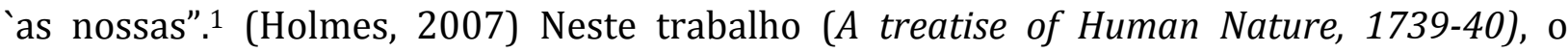
conceito de "simpatia" envolve comunicação (simpatética) de sentimentos, "simpatia delicada" que permite a apreensão minuciosa de características, e ainda está relacionada ao poder de sugestão, ou “contágio emocional”, ou, ainda `a "impressão correspondente".

Sob influência do conceito de simpatia de Hume, especialmente definida como a possibilidade de que uma mente torne-se espelho de outra, Theodor Lipps desenvolveu, seu conceito de Einfühlung (empatia). Interessado na descrição de processos psicológicos, seu modelo teórico da Einfühlung, explicava tanto ilusões de óptica como a forma pela qual se compreende estados de mente do Outro. De acordo com Lipps isso se daria por uma fusão entre o observador e seu objeto, processo inconsciente baseado na 'imitação interna'. Tentou desenvolver uma teoria 'estético-mecânica' compreensiva que explicasse todos os tipos de ilusões geométricas. As ilusões não seriam erros de percepção, mas seriam provenientes de erros de julgamento, estes subjacentes `as experiências pessoais formadas por 'analogia inconsciente' e 'inferência'. Lipps acreditava que nossa experiência pode nos levar a ver uma atividade de 'força' e 'tendência' em formas geométricas pela projeção de atividade vivente em objetos. Aparece no seu trabalho a ilusão de intersecção de duas ondas na figura, apesar de os segmentos de reta estarem paralelamente alinhados entre si. Ele usou o exemplo de um acrobrata e sugeriu que os movimentos percebidos e as expressões afetivas são simultaneamente espelhadas por esforços cinestésicos e pela experiência correspondente no observador. Em 1909 Edward Tichener traduziu Einfühlung

\footnotetext{
1 "A cheerful countenance infuses a sensible complacency and serenity into my mind; as an angry or sorrowful one throws a sudden dump upon me. Hatred, resentment, esteem, love, courage, mirth and melancholy; all these passions I feel more from communication that from my own natural temper and disposition." (Hume, in Holmes, 2007, p.395)
} 
como empatia (empathy) (Etlin, 1998), e o conceito tomou diversos caminhos na psicologia e psicanálise.

\section{I.3. Relevância do tema}

Discutir sobre empatia nos parece relevante em termos sociais, ou de um sistema de valores válido num coletivo específico, pois sofremos o risco do narcisismo excessivo, que quando autorizado por mecanismos culturais impede que o Outro apareça ou seja ouvido. A empatia, que na psicanálise decorre de processos identificatórios, permite a uma leitura dos movimentos de grupos totalitários, no qual privilégios determinados narcisicamente ou ilusões compartilhadas tomam o lugar da possibilidade de expressão e reconhecimento do outro na sua alteridade. Um dos perigos da atividade do psicanalista excessivamente narcisista é apontado como a inibição da curiosidade e, portanto, da expansão da mente, pela necessidade de demonstrar sua capacidade interpretativa (Zimerman, 2004).

Na clínica, há uma tendência crescente do relacionar-se baseada na desconsideração, no uso e na manipulação do outro, como se observa nos desvios de personalidade denominadas sociopatias que acompanham, em graus diversos, um sentimento 'de não sentir' prazer ou dor, acompanhado de um falso sentimento de vitalidade. Ferenczi, psicanalista húngaro, se refere `a anestesia psíquica dcorrente do trauma, como uma forma de distanciar-se de si-mesmo, e aniquilar o sentimento de dor. Estar fora de si, fora do tempo e do espaço, apresenta-se como providência necessária para suportar a dor intensa decorrente do trauma. Nesse sentido, uma dor não experienciada, posto a sua ausência de legitimidade, tem um efeito anestésico sobre o si-mesmo (Herzog e Mello, 2009).

Sobre a superficialidade na relação com o outro, a "cultura do descartável" estimula o acesso a objetos desejáveis, a ponto de serem transformados em objetos de necessidade, 
que alimentam ilusões de preenchimento, e a volta ao um estado de bem aventurança original. A forma de estarmos no mundo no séc XXI, ou na pós-modernidade, com forte acento tecnológico, modifica a visão de mundo, natureza e homem. Derivada do conceito de cogito, como o de consciência racional que supera limites de diversos tipos, desvaloriza o mundo vivido, e o corpo, como mais um dentre objetos a serem consumidos. A valorização do ego e desvalorização dos aspectos afetivos trazem a idéia de um homem enclausurado em si mesmo, semelhante a um corpo-máquina composto por habilidades autônomas. Daí também advém o corpo sexualizado e exposto, valorizado no seu aspecto especular, mas desvalorizado enquanto corpo de sentido e Outro.

Portanto, considerando-se que o sistema capitalista prevê o surgimento ininterrupto de novas formas de sedução e consumo que distanciam o homem da possibilidade de um encontro genuíno com o outro, e condiciona a incomunicabilidade, a escolha do tema tem um caráter político. Por outro lado, se observa também na prática de produção acadêmica uma crescente tendência de considerar a ciência subjugada `a tecnologia - o poder de persuasão pela repetição de uma falsa conexão, tantas vezes quantas forem necessárias, até que se torne uma verdade. Esta pesquisa inclui o diálogo entre a psicanálise e a neurociência. Há apenas um duplo interesse, duas línguas diversas que com suas limitações, remetem `a idéia de homem. Consideramos um 'mau-uso' a relação de domínio de um dos campos de conhecimento por outro. Aquele que se interesse pela interlocução entre neurociências e psicanálise deve considerar que as diferenças suplantam as possíveis concordâncias, especialmente quanto à forma de colocar questões, e, portanto, quanto às respostas encontradas. De fato, caberia a questão, repetida por muitos: porque falar em diferenças, dado que semelhanças não existem... Este trabalho não tem a ambição de resolver discordâncias históricas, mas, apenas, evita pré-conceitos sobre 
onde depositar maior confiança - na psicanálise omo teoria, e porque não nas neurociências, em diversos aspectos de investigação do 'real'.

É importante ressaltar que algumas vertentes da psicologia desconsideram uma investigação do que é denominado como "realidade". A hipótese sobre a empatia como “sensibilidade”, ou capacidade de ser afetado pelo 'Outro', decorre da insatisfação pessoal quanto `a forma como a questão intersubjetiva vem sendo desenvolvida.

Em termos da coletividade, aceitamos a acepcão de Levinas, filósofo fenomenólogo, segundo a qual há uma relação originária de responsabilidade entre os homens, ou entre Eu e o Outro, pautada na heterogeneidade radical do Outro. Para Levinas a relação baseada no poder advém da identificação do Eu com um outro que perde sua imagem própria como resultado do subjetivismo. Aparece o Mesmo apoderando-se num ato de poder de tudo o que se encontra `a sua volta, o Eu imbuído da meta do Mesmo então transforma o diferente ou estranho no familiar, e a alteridade do Outro decompõe-se neutralizada por tudo o que lhe é estranho (Levinas, 2008).

A empatia, ou abertura de certa qualidade afetiva, na medida da apreensão afetiva do Outro na assimetria própria da relação Eu-Outro, do nosso ponto de vista, é fundamental para a vida ética em sociedade. Permitiria diminuir a importância das narrativas formuladas por julgamentos distanciados. Temos possibilidade de desenvolver uma sociedade na qual prevaleça o pensamento que considera o Outro e os direitos humanos que deveriam legitimá-la. A sociedade tem o dever de se encaminhar para a superação do que entendemos como 'alienação', que na psicanálise depende de um mecanismo de gênese traumática.

A empatia portanto, na medida em que destaca o outro (ou rosto na acepção de Levinas) enquanto alteridade e por meio da sensibilidade própria (fruição, para Levinas), coloca em suspensão o valor das narrativas ou da retórica que defende a racionalização do 
verossímil, ou, ainda, o fascínio enganador (remetido ao grego hypocrísis) a que se prestam as palavras. As imagens, como formas "imitadoras" do real, e dentro do contexto de perversão também propiciam um tipo de alienação.

Estudos neurocientíficos sobre imagem corporal, imitação, leitura da mente e empatia partem da idéia de um mecanismo neuroanátomo-funcional, que possibita a formação do campo intersujetivo. A revisão crítica destes estudos demonstra organização que pretende apreender o Outro. Constituída por mecanismos que dependem da atividade de `areas pré-motoras foi posteriormente ampliada, incluindo diversas outras áreas corticais, e permite explicar como a mente social funciona (Gallese 2003). Nosso interesse é realizar uma análise crítica dos estudos desta área, que tem sido relacionados com elementos da psicanálise e da fenomenologia (Gallese, 2007). Do nosso ponto de vista, o tema sobre o estatuto que resultados de neuroimagem devem ter dentro da psicologia merece ser aprofundado.

$\mathrm{Na}$ origem da psicanálise (Freud), a empatia depende de mecanismos de identificação. Na medida que diz respeito ao estabelecimento da relação intersubjetiva, a empatia também depende da experiência contra-transferencial vivida pelo analista, ou pelo: “tipo de confusão causado pela identificação projetiva em que a mente do paciente confunde seus próprios atributos com os do analista" (Caper, 2002, p.205). Porém, patologias psicossomáticas, especialmente relacionadas `a dor e ao traumático exigem novas elaborações sobre a intersubjetividade.

Do nosso ponto de vista, se impõe a necessidade do desenvolvimento de uma percepção sensível do mundo e do Outro, intrínseca ao humano, de forma a devolvê-lo ao seu campo originário.

Pautados nos conceitos de autores da psicanálise, fenomenologia e neurociência, consideramos que a empatia pertence a duas qualidades de experiência: (1) contágio emocional ou 
ressonância de afeto pela qual o eu-outro perdem suas fronteiras definidas; que não acompanha a idéia do Outro como alteridade (emoções primárias, comunicação inconsciente de afeto, identificação projetiva, compreensão originária do ser-no-mundo) e, (2) identificação que decorre da imagem/representação do corpo por espelhamento e mimetismo.

Nosso objetivo é desenvolver um conceito integral (Morin, 1990) de empatia, que inclua seus múltiplos níveis de compreensão, partindo da premissa de sua complexidade enquanto fenômeno. 
Capítulo II - A produção de conhecimento

II.1. A produção de conhecimento na psicanálise: subjetivismo e verdade

A psicanálise se fundou na idéia de recalque, e conflito intrapsíquico inerente à formação do Eu. "Dos atos que possam provocar desprazer a atividade psíquica se recolhe" (Freud, 1911, p. 65) Em Freud, o Eu é a instância principal da consciência, que apesar de ter suas bases no inconsciente, deve lidar com instâncias controladoras (superegóicas) e com o pulsional do Id, fazendo valer o 'princípio de realidade', ou de 'prazer-adiado', em detrimento do princípio de prazer-desprazer, de descarga imediata. O Eu enquanto instância psíquica que dá conta do princípio de realidade (Porchat, 2005), ou de prazer adiado, em contraposição ao princípio prazer-desprazer, desenvolve-se com diversas habilidades, como atenção, memória, capacidade de processar elementos perceptivos e sensoriais, efetuando, por meio do "processo secundário", ligação entre elementos, e ordenação segundo o tempo linear. Por meio do teste de realidade o Eu confronta fantasia com realidade e se relaciona com o compartilhado socialmente, sendo moldado também por ele. um agir", (Freud, 1911, p.66) viabilizado pelo processo do pensar.

Retornando à Freud a consciência é descrita com um papel limitado: “O que a consciência produz consiste essencialmente em percepções de excitações provindas do mundo externo e de sentimentos de prazer e desprazer que só podem surgir no interior do aparelho psíquico; assim, é possível atribuir ao sistema Pcpt-Cs (perceptivo-consciente) uma posição no espaço. Ele deve ficar na linha fronteiriça entre o exterior e o interior; tem que achar-se voltado ao mundo externo e tem que envolver outros sistemas psíquicos." (Freud, 1920, p.39) Podemos sugerir que a empatia, segundo este modelo se daria entre o sistema pré-consciente e consciente e devido ao destino da pulsão e ao que se manifesta na transferência. A relação entre a pulsão e a representação (figuração investida 
pulsionalmente) surgiu em 1900, nos primeiros modelos teóricos psicanalíticos para explicar as psiconeuroses.

Os aspectos intoleráveis da mente, ou pensamentos que não deveriam ocorrer são recalcados, expulsos da consciência e enviados para o inconsciente onde exercem vida própria. Um pensamento reprimido, não está mais sujeito à contradição se confrontado com outros pensamentos ou aos efeitos corretivos de experiências subseqüentes. Porém, este pensamento reprimido exerce impacto sobre a mente e sua força decorre precisamente de ter sido reprimido e, desse modo, afastado das influências moderadoras das idéias e percepções conscientes. A repressão danifica o Eu ao retirar de seu domínio aquilo que poderia ser uma idéia, pois deixa apenas o que Freud denominou 'representação de coisas' que o afeta mas não tem capacidade de se ligar e, portanto não podem ser pensadas à luz de outras idéias e experiências (Caper, 2002, p.204). A representação contém em si um "quantum de afeto" que é sucessivamente deslocado de uma representação para outra a partir de mecanismos de defesa. 0 destino da pulsão e do conteúdo do qual o indivíduo quer se defender será diverso na Histeria, Obsessão, Confusão Alucinatória e Paranóia (psiconeuroses de defesa).

\section{II.1.1. Verdade em Freud}

A verdade em psicanálise depende do conceito de "verdade emocional" pois que predomina a "fantasia" em detrimento de um real materializado. Nas ciências, por outro lado, pensamento imagético se situa no campo da fantasia e considerando o binômio verdadeiro/falso, o falso seria o campo da imaginação.

Freud afirma: “A idéia que nos é oferecida é a de lugar psíquico. Afastemos imediatamente a noção de localização anatômica. Permaneçamos no terreno psicológico e apenas tentemos imaginar o instrumento que serve para as produções psíquicas como uma 
espécie de microscópio complicado, de aparelho fotográfico etc. 0 lugar psíquico corresponderá a um ponto desse aparelho onde se forma a imagem. No microscópio e no telescópio, sabemos que estes são pontos ideais aos quais não corresponde nenhuma parte tangível do aparelho." (Freud, 1900, In: Huot, p.96-97)

“O interesse científico de Freud se deslocou: o que lhe interessa não é mais o que se vê através do microscópio, lâminas de células ou cenas traumáticas, mas o lugar onde se forma a imagem, lugar irreal, lugar psíquico, outra cena. 0 termo cena aplica-se aliás muito bem ao sonho, pois: 0 sonho organiza essas imagens em cena, representa as coisas como se fossem atuais, dramatiza uma idéia, segundo expressão de Spitta." (Idem, Ibid.)

Freud no seu trabalho "Totem e Tabu” (1912) revisa estudos de antropologia social e de psicologia (como de Wundt e Jung) para caracterizar a universalidade, no homem, do tabu do incesto. Demonstra que os primeiros sistemas penais humanos decorrem da existência de diversos tipos de tabu que incluem o temor e proibições aos quais povos primitivos estão sujeitos. Tabus afetam certos objetos, certas palavras e nomes próprios (que devem ser mantidos em segredo), animais (que não podem ser mortos e comidos), seres humanos e seus objetos pessoais e, de forma menos estáveis, árvores, plantas, casas e localidades. Qualquer violação involuntária a um tabu transforma o próprio agressor em tabu. "Pessoas ou coisas consideradas como tabu podem ser comparados a objetos carregados de eletricidade; são a sede de um imenso poder transmissível por contato e que pode ser liberado com efeito destrutivo se os organismos que provocam sua descarga são fracos demais para resistir a ele; o resultado da violação de um tabu depende em parte da influência mágica inerente ao objeto ou pessoa tabu, em parte da força do mana antagônico do violador do tabu (...)". (Idem, p.40) 0 tabu tem sua fonte mais primitiva e duradoura no poder demoníaco que se acredita subsistir em um "objeto tabu". Aos poucos o tabu vai se tornando norma com força própria. Freud relaciona, segundo a lei da doença neurótica, 
alguns tabus com proibições e sintomas obsessivos. Instintos retidos por meio de fixações psíquicas ou vivências que não foram manejadas, como o desejo de tocar uma pessoa ou suas partes proibidas sofrem a proibição imposta. 0 desejo inconsciente persegue sua descarga ou sua vítima externa ou interna, também por meio do deslocamento, por meios associativos, a objetos substitutos, de forma obsessiva, num ciclo de novas estimulações que mantém tanto o desejo quanto as proibições, que também buscam novos objetivos. "As duas mais antigas e importantes proibições ligadas as tabus são as duas leis básicas do totemismo: não matar o animal totêmico e evitar relações sexuais com membros do clã totêmico do sexo oposto" (Idem, p.52). Aquele que viola um tabu torna-se tabu por incentivar a imitação que levaria `a dissolucão da sociedade. "Se a violação não fosse vingada pelos outros membros, eles se dariam conta de desejar agir da mesma maneira que o transgressor". (Idem, p.53) Mas uma pessoa pode ser definitiva ou temporariamente tabu caso provoque desejos proibidos e despertem nas pessoas um desejo ambivalente.

A morte de um homem também está submetida ao tabu. Deve-se considerar a observância de elementos importantes quando do exercício de crueldade dos povos selvagens dirigida aos inimigos, que permite, dentre outras coisas, que se livrem do temor da alma do morto: apaziguar a alma assassinada de diversas formas (depois de trazerem a cabeça do inimigo vencido); restrições de comportamento `aquele que matou; expiação e atos cerimoniais, que o purificam corporal e espiritualmente; evitação, ou alteração do nome do morto e de seus parentes.

Freud considera que a transmissibilidade do tabu explica as tentativas de expulsá-lo em cerimônias purificatórias. Os tabus e seus efeitos destrutivos podem ser permanentes ou temporários, e o potencial das cargas e do seu potencial de infecção ou contágio também geram maior ou menor perigo. 0 poder do mana, santidade e dignidade de sacerdotes e chefes que por exemplo curam pessoas pelo toque, exige sua proteção física e de seus 
objetos. "A etiqueta de tabus a que toda a vida do rei está submetida está a serviço de todos estes intuitos protetores ao mesmo tempo: a sua própria proteção dos perigos e a proteção de seus súditos dos perigos que os ameaça". (Idem, p.69) Freud afirma, na sua análise psicanalítica, que: "a imagem que um filho faz do pai é habitualmente investida de poderes excessivos desta espécie (...)" (Idem, p.71).

A inveja, rancor e o delírio persecutório é atribuída por Freud `a projeção de hostilidade inconsciente. Freud acreditava que os impulsos maus projetados na figura de um demônio eram acompanhados de culpa (castigo e remorso). A "consciência tabu" (Idem, p.89), ou um tipo específico de ambivalência e suas decorrências, é descrito neste trabalho como a forma mais remota de consciência. "Dessa forma parece provável que também a consciência tenha surgido numa base de ambivalência emocional, de relações humanas bastante específicas, `as quais esta ambivalência estava ligada e que surgiu sob as condições que demonstramos se aplicarem ao caso do tabu e da neurose obsessiva, a saber: que um dos sentimentos opostos envolvidos seja inconsciente e mantido sob repressão pela dominação compulsiva do outro." (Idem, p.90)

A liberdade de comer animais totêmicos no mais antigo cerimonial da humanidade seria a repetição do parricidio cometido de fato pelo homem primitivo, ou de seus filhos contra o pai. 0 assassinato, cometido pelos filhos e irmãos entre si contra o pai, deu-se pelo fato de desejarem para si as mulheres pertencentes ao pai tirânico e poderoso. Após o parricídio ter sido executado, nenhum dos irmãos teve plena satisfação de seus desejos primitivos, quais sejam, ocupar o lugar do pai e, ter todas as mulheres da horda. Antes do assassinato, os irmãos dominados pelos sentimentos hostis odiavam o pai violentamente mas, ao mesmo tempo, o amavam e o admiravam. Com a morte, o pai morto torna-se mais forte do que quando vivo, devido ao remorso ou sentimento consciência de culpa. Da culpa surgiram os dois tabus do totemismo correspondentes aos dois desejos reprimidos do 
complexo de Édipo: o homicídio e o incesto. Simbolicamente, todos nós matamos nossos pais pelo desejo de união com nossas mães. A refeição totêmica, ou a lembrança do primeiro grande ato da morte cerimonial do pai, foi o começo da organização social, das restrições morais e da religião. Para Freud, a paixão de Cristo representa a redenção do conjunto de irmãos deste "pecado original" pelo sacrifício de sua própria vida.

\section{II.1.2. Influência de Kant na psicanálise}

Vale a pena a breve referência a alguns conceitos da filosofia Emmanuel Kant (17241804) no sistema desenvolvido na Crítica da razão pura (1781), pois serviu de fundamento epistemológico para a psicanálise. Para Kant o conhecimento do fenômeno se dá pela 'síntese a priori' que reúne suas partes, aquela intuída na sensibilidade, sem a qual nenhum objeto nos seria dado, e outra faculdade, efetivada no entendimento. Na primeira etapa do conhecimento por meio da intuição temos as formas `a priori de primeiro grau e no segundo passo se alcançam as formas `a priori de segundo grau, denominadas categorias do entendimento. A 'síntese a priori', portanto, reune `a matéria do mundo exterior ou a forma a universalidade do conteúdo. “Assim, a filosofia kantiana termina por resolver, segundo o seu sistema, a problemática essencial do conhecimento, ou seja, a validade e a aplicabilidade dos juízos sintéticos a priori na matemática e nas ciências naturais" (Silva, 1998/1999). Sua abordagem supera ambas as vertentes, racionalista dogmática pautada em juízos de explicação, e o empirismo céptico, fundamentado nos juízos de extensão. A consciência do homem conforma a multiplicidade do mundo sensível por meio da sua sensiblidade, que permite a intuição dos objetos. As formas a priori da sensibilidade ou intuição puras são o espaço e o tempo, sem as quais não há experiência. Os fenômenos possuem uma 'idealidade transcendental' pois existem no homem apenas como formas da sua sensibilidade, independentemente da realidade em si. 
Kant concebe também o elemento transcendente incondicionado, denominado 'objetos noumenicos' que não podem ser objeto de conhecimento do homem (por exemplo alma). 0 nôumeno difere do fenômeno pois este é a coisa tal como aparece no mundo dos sentidos, e portanto está sujeito `a percepção pelas faculdades cognitivas do homem, dando origem ao conhecimento. De outra perspectiva, a "coisa em si", "coisa incognoscível” ou "ser de pensamento" não pode, em hipótese alguma, ser acessado pois não se sujeita `as formas inseparáveis da sensibilidade e entendimento humanos. Aos nôumenos também não se aplicam juízos sintéticos a priori e, portanto, não são objetos de conhecimento.

\section{II.1.3. Nova(s) psicanálise(s)}

Além da influencia de Kant epistemologia psicanalítica esta deve parte de seus pressupostos do movimento romântico. Como afirma Sandler: "A consequência maior do movimento romântico, que penso ser a psicanálise mesma, proveniente da medicina e da ciência, foi considerar a mente como intrumento, método e objeto de estudo." (Sandler, 2000, p.32)

A psicanálise poderia ser pensada como uma disciplina hermenêutica (interpretativa), ou a interpretação enquanto criação de sentido dado, a permite incluir na sua prática um conceito de verdade? "0 paradoxo que pede tolerância consiste em que não se pode conhecer inteiramente a mente, mas que ela existe e pode ser apreendida de forma parcial, através de vivos e efêmeros insights" (Sandler, 2001, p. 231). Inscrita ou não em um campo hermenêutico enquanto disciplina, a psicanálise possibilita o pensamento sobre verdades do humano, tema que considero fundamental para a prática e pesquisa analítica.

Para que seja possível um pensamento, seguindo a vertente de Wilfred Bion, se coloca em atividade mecanismos de projeção e introjeção, que permitem a assimilação suave das impressões sensoriais, típica da posição depressiva. Bion assinala que em 
pacientes graves o uso maciço do mecanismo de identificação projetiva prejudica o acesso `a 'realidade’ e `a realidade psíquica. Da mesma forma, o 'ataque aos elos de ligação' típica da posição esquizoparanóide, impede a função simbólica. 0 pensamento, de seu ponto de vista, se estabelece por meio dos elos de ligação, ou da conjugação entre impressões de objeto que constitui uma primitiva "matriz de ideogramas" (ou de elementos- $\beta$ ). Os elementos- $\alpha$, termo que inclui o trabalho efetivado pela função- $\alpha$ sobre as impressões sensoriais, mantém correspondência com o que Kant denomina como "formas a priori de segundo grau", ou categorias de entendimento.

Bion supunha existir uma hierarquia de pensamentos desde o nível mais inferior até aos pensamentos puros. A formação de símbolos depende da habilidade para juntar objetos discriminando a semelhança e a diferença entre eles e difere da utilizacão de 'sinais'. 0 conceito de Bion de pensamento incipiente inclui o uso de "sinais" pelos quais objetos são pensados não distinguidos de coisas da forma. Na base da escala, portanto, estão os elementos que não são psíquicos nem materiais, denominados como elemento- $\beta$. Compartilham qualidades com o objeto inanimado e com o objeto psíquico. A noção de verdade em psicanálise provém da premissa da realidade psíquica análoga `a tese kantiana da apreensão sensorial do real, e inclui a "coisa em si".

Para Bion e na psicanálise em geral, assim como na Antiguidade grega, toda verdade é enigma. Mythos ou narrativa mítica, é a dimensão na qual o homem apreende, imageticamente, de eventos universais, elementos particulares, para enfrentar questões fundamentais (Bion 2004; Fontanari, 2008). Em termos epistemológicos Verdade (Alétheia) é não-oculto, não dissimulado e não-esquecimento. 0 contrário da verdade não seria a mentira, mas o esquecimento. Ambos não mantém entre si uma relação não contraditória, considerando que não vigora o princípio da identidade. 
Descreve a importância enquanto "pré-concepção" do mito de Édipo, além do campo pessoal, devido ao seu status público e racial. 0 mito de Édipo seria a contraparte primitiva e vital da mente que tem correspondência com um aparelho de aprendizado em estágios primitivos do desenvolvimento - ou seja, permite que vários elementos discerníveis de um ego desintegrado assumam nova importância, ou seu lugar na relação com os pais. Préconcepção corresponde a um estado de expectativa para certos eventos que quando correspondida como a expectativa que tem um bebê do seio, torna-se uma concepção. A pré-concepção livra a concepção do caráter de verdade, pois que surge de uma expectativa do investigador (bebê) e quando expressa a própria expectativa, serve como uma préconcepção. “A concepção pode ser considerada uma variável que foi substituída por uma constante" (Bion, 2004, p.38).

Bion afirma: “A pré-concepção poderá ser vista como objeto análogo, em psicanálise, do conceito kantiano de "pensamentos vazios". O conceito de "pensamento puro" ou categoria, em Kant decorre da síntese pura do entendimento que reúne segundo a lógica transcendental, o múltiplo das intuições puras (espaço e tempo) sob conceitos puros, que sem a matéria (sensibilidade) fornecida pela intuição seriam vazios.

A psicanálise, para Bion, tem as três seguintes dimensões: sentido, mito e paixão. Ou seja, aquilo que é interpretado deve ser um objeto do sentido; a dimensão da paixão, ou sua falta, não depende dos sentidos, mas sim da premissa de vinculação entre duas mentes, apesar de que possa ocorrer apenas em uma. Bion afirma três formas de vinculação fundamentais: L (amor), H (ódio) e K (conhecimento). Por fim, falta na categoria C da grade estão os pensamentos oníricos, sonhos e mitos. Os mitos podem funcionar como préconcepcão, como dissemos, e auxiliar ao desenvolvimento do pensamento. Bion entende, por exemplo que ambos, o mito de Édipo e a psicanálise, foram mutuamente úteis enquanto "instrumento", ou seja o mito auxiliou Freud a descobrir a psicanálise, e a própria 
psicanálise foi o instrumento que capacitou Freud a descobrir o complexo de Édipo. 0 sonho pode ser considerado um mito privado.

Na genesis, a prova imposta dos homens, foi a proibição de comer do fruto da árvore do conhecimento do bem e do mal. Era, em última instância, uma prova de obediência à vontade de Deus. Satanás tentou Eva, primeiro, fazendo-a duvidar da bondade de Deus, pois Ele lhes vedara acesso a uma árvore (Biblia, Gn 3.1, “Não comereis de todas as árvores do jardim?"). Ofereceu `a Eva um plano substituto, afirmando que "Não, vossa morte não está marcada. É que Deus sabe que no dia em que do fruto comerdes, vossos olhos se abrirão e sereis como deuses, possuindo o conhecimento do que seja bom ou mau" (Biblia, Gn). "A mulher viu que a árvore era boa de comer, sedutora de se olhar, preciosa para se agir com clarividência", e encontrou as justificativas para seu ato de comer o fruto (v. 6). Por fim, Eva comeu e ofereceu a Adão, que a seguiu. "Os olhos de ambos se abriram e souberam que estavam nus". As penalidades da queda: (1) sobre a serpente: maldição eterna; hostilidade entre satanás e a mulher, e entre duas descendências. A descendência da mulher (mãe de Jesus) te atingirá a cabeça, e tu lhe atingirás o calcanhar. "Ela, a mulher, te esmagará." Sobre a raça, o castigo foi o rompimento da comunhão com Deus. Além da morte física e expulsão do Éden, Bion entende que um Deus, pertencente a um sistema moral, gera o desfecho `a humanidade que inclui: culpa, nudez e banimento, devido `a sua desobediência. Da mesma forma, no mito da Torre de Babel, Deus acaba com a lingua única divina e advém a confusão eterna de linguagens e modos de conhecer, dispersão que segundo nossa concepção a qual os humanos estão condenados.

Esta dispersão pode ser apreendida dentro da própria psicanálise. Winnicott, por exemplo, considerado um autor do Independent Group of the British Psycho-Analytical Society, desenvolveu uma psicanálise própria, com pressupostos que em muitos pontos se distanciaram da metapsicologia freudiana e do desenvolvimento proposto por Klein. 
Dentre as principais diferenças vale citar que Winnicott não considerava que a vida fosse colocada em movimento por 'forças pulsionais em conflito', ou que um psiquismo estivesse sujeito às forças pulsionais do Isso (Es) e fosse organizado segundo um 'aparelho' que, segundo ele, pertenceria ao mesmo âmbito das forças físicas e seus mecanismos correspondentes. Desenvolveu o conceito de felso e verdadeiro self. Melanie Klein, por outro lado, descreve a tensão do aparelho em duas ansiedades esquizoparanóide ou a depressiva, que se mantém durante toda a vida e que podem estar exacerbadas em diferentes períodos do desenvolvimento, também devido aos fatores ambientais.

A leitura que Thomas Ogden faz do conceito de "posição" elaborado por Melanie Klein carece de clareza. Ele afirma que se pressupõe um sujeito que existe em uma relação dialética (ou de tensão) entre "posições" (sobre posição esquizoparanóide e posição depressiva, vide capítulo III1.3.). Supomos portanto que o próximo passo é que ele se refira a uma síntese entre posições - o que seria insólito visto que, em Klein, a posição depressiva é uma experiência diversa da experiência da posição esquizoparanóide pela qualidade da ansiedade presente - supõe uma cisão da mente. Porém, sua leitura entende que é intrínseco `a dialética entre as posições duas formas temporais, uma que evolui em um eixo temporal sequencial (eixo diacrônico) e, outra, que se dá na simultâneidade das posições, ou eixo sincrônico. Ou seja há uma tensão simultânea e uma tensão diacrônica? Ele afirma: “O sujeito psicanalítico é, portanto, dialeticamente constituído (simultaneamente) dentro e fora do tempo diacrônico, convencionalmente medido". Ou seja, para Ogden o aspecto sincrônico demonstra que Melanie Klein está de acordo com a atemporalidade do inconsciente (Ogden, 1996).

A obra de Melanie Klein ocupa um lugar central no desenvolvimento da teoria de Wilfred Bion. Partindo da premissa dos objetos internos e das duas posições fundamentais do aparelho mental, posição depressiva e posicão esquizoparanóide, Bion acrescenta 
inúmeros elementos hipotéticos dentre os quais se destacam os "elementos- $\alpha$ " e "elementos- $\beta$ ". A verdade psíquica apenas é e se torna, quando não é expulsa pela identificação projetiva, por ódio `a realidade.

A psicanálise, portanto, se transformou no decorrer de sua práxis inclusive quanto ao conceito de inconsciente. Bion define " 0 " como realidade última, verdade absoluta, divindade, infinito e coisa-em-si. "O" não incide no âmbito do conhecimento, a não ser por evoluções (o analista deve esperar que "O" se torne manfesto em "K") e não pode ser conhecido, mas pode "tornar-se", ou seja, passa ao âmbito de K (a ponto de ser conhecido) por intermédio de um conhecimento obtido por experiência, como derivado da experiência sensorial. No analista, "O" representa o ponto de partida do desconhecido, ou seja, seu vértice psicanalítico que o permite conhecer as evoluções de "O". Ou seja, não é possível conhecer o " 0 " do qual o paciente é uma evolução, mas pode conhecer o que o paciente aparenta ser. James Grotstein, que segue a teoria de Bion, pergunta: "as pulsões, seriam as ansiedades primárias do inconsciente, como Freud propôs, ou a infinitude e as infinitas posições como Matte-Blanco sugeriu?". (Grotstein, 2003, pg.122) Grotstein afirma que a idéia da infinitude provém da idéia de que as pulsões não cessam de manifestar-se enquanto "significantes semióticos" nas formas não lineares como caos ou formas de autoorganização referindo-se ao "O". Portanto, apesar de não usar a denominação self , Bion se refere "aquilo que o paciente realmente é" ou tudo aquilo que é desconhecido para o paciente. 0 "O" pode evoluir para uma interpretação, quando amparado na intuição. Transformações de K (conhecimento) em "O" significa transformar o intelectivo-cognitivo em "vir a ser esse algo". Transformações em "O" é o mesmo que "vir a ser aquilo que, realmente, ele é" (Zimerman, 2004, pg.170). "Por outro lado, Zimerman afirma que essa conceituação de "O", em um certo sentido, aproxima Bion dos conhecidos postulados por Winnicott acerca do "verdadeiro" e "falso self"." (Idem, p.174) Bion, de fato, afirma que 
"não pode haver nenhum resultado genuíno baseado em falsidade" (Bion, 2004b, p.43) e, portanto, o resultado da interpretação depende da intimidade com que a avaliação interpretativa se aproxima da verdade. É importante para o tema em questão a passagem na qual ele afirma que esta intimidade (entre avaliações interpretativas ou percepções de “0") deriva da capacidade para estarmos unos (at one) com a realidade do paciente. Bion considera que "quanto mais "real" for o psicanalista, mais ele pode "estar uno" com a realidade do paciente e próximo da "verdade absoluta em todo e qualquer objeto" (Bion, 2004b, p.44), ou seja "0". O método inclui uma "disciplina positiva" que o abstenha de qualquer background sensorial, memória e qualquer desejo, ou seja, reminiscências e antecipacões. 0 estado de mente científico exigido ("bem-vindo") é a "fé" - fé que Bion difere de seu significado religioso, mas que afirma a existência uma realidade última, ou infinito desprovido de forma, incognoscível e, nesse sentido, memórias e desejos são características que o analista necessariamente encontra, mas são "inúteis".

O estado de mente do analista se parece com o primeiro passo da redução fenomenológica, na medida da suspensão do background sensorial para que surja uma nova sensibilidade. De fato, a palavra sensibilidade se adequa ao contexto, na medida em que a sensibilidade é definida como: 1 . habilidade para sentir ou perceber; 2.a. habilidade imediata perceptiva (a sensibilidade de um pintor `a cor); 2.b.responsividade mental ou emocional em relação a algo, como os sentimentos de outrem; 3. Receptividade `a impressão, prazerosa ou desprazerosa; agudeza de sentimento (o sofrimento do povo cubano chocou nossa sensibilidade); 4. conhecimento refinado e compreesão sensível do valor estético.

Memórias e desejos tornam-se úteis quando a transformação, ou uma nova formulacão de "O", exige que se evoque para que se remova os elementos evocados, instaurando uma nova "conjunção constante". A evocação neste caso pode decorrer (a) da 
avidez sensorial: os impulsos de possessividade geram memória e desejo que geram, avidez sensorial; ou (b) do estado de "estar uno a", ou seja pela semelhança do aspecto de “0” com a satisfação sensorial pregressa. Bion, nos indica a descrição do "analista real”, com a afirmação de que é difícil uma análise satisfatória sem que o analisando se "reconcilie consigo mesmo", ou se torne "uno-a" si mesmo.

A alucinose, pela qual um evento mental é transformado em uma impressão sensorial, se torna demonstrável em sua plena riqueza e profundidade no "ato de fé", sempre presente ainda que encoberto, que tem como background algo que é inconsciente e desconhecido. Sobre a atemporalidade do inconsciente, também é necessário o conceito de pré-concepção de Bion (Bion, 2004b), como veremos abaixo. Freud já apresentava o "fantasiar" e o "devanear" como a atividade do pensar livre do princípio de realidade e submetido apenas ao princípio de prazer, com origem e satisfação respectivamente, no auto-erotismo e no corpo. "Em sua origem, o pensar era provavelmente inconsciente, ultrapassava apenas o ato de visualizar mentalmente (vorstellen) e se dirigia só `as relações entre as impressões deixadas pelo objeto. Somente adquiriu qualidades perceptíveis `a consciência por meio da fixacão (bindung) a restos de palavras" (Freud, 1911, p. 67).

Analogamente ao pensamento de Kant, Bion postula que o campo da percepção e da comunicação do percebido são mediadas sensorialmente. Porém, como vimos, o aparato sensorial não esgota a questão da realidade psíquica (Sandler, 2000). 0 conceito de transcendência não se aplica `a transcendência que acessa o desconhecido no sentido metafísico, mas do desconhecido de si para si mesmo. Segundo Sandler, "transcendência" não se aplica `a uma verdade absoluta, mas ao paradoxo "realidade psíquica e sensorial”, e pode ser apreendida por meio dos mitos, que são e se tornam (Sandler, 2000). Ogden no prefácio dedicado ao trabalho de Grotstein (Quem é o sonhador que sonha o sonho?) arrisca sua própria elaboração do conceito de transcendência como “é um estado 
psicológico no qual a pessoa penetra profundamente na vida cotidiana (e há outra vida?) e sente alguma coisa além, que satura e anima (...)” (in Grotstein, 2003, p.21).

Thomas Ogden (2003) psicanalista que desenvolve a vertente de Wilfred Bion descreve a prática da psicanálise segundo um esforço da parte do analista e do analisando para que seja dito 'algo' que seja sentido por ambos como verdade da experiência emocional de um dado momento, e que o dito seja útil ao par analítico, enquanto material para trabalho psicológico. Ogden afirma que a troca analítica adquire a articulação de algo que é verdade, ou ao menos 'relativamente verdadeiro' e, como analistas, estamos todo o tempo respondendo `a questão daquilo que pode ou não ser verdade. Quanto `a verdade sobre o 'mundo objetal interno inconsciente' formulada por Klein ou o que foi denominado por Fairbairn como 'teoria das relações objetais', pode ser encontrada de forma rudimentar na obra de Freud (Freud, 1917), ou seja, sem que o próprio Freud tivesse conhecimento das implicações teóricas de suas idéias. A influência teórica estaria para além da ordem cronológica, pois, segundo ele, mediado pelo leitor, contribuições posteriores influenciam leituras de textos escritos anteriormente. Portanto, levando a idéia ao extremo, a idéia de Freud é criação de ambos, Freud e seus leitores, e de nenhum (Ogden, 2003).

Bion, fonte de inspiracão para Ogden, portanto inverte a ordem de determinação causal passado-futuro, demonstrando que o futuro pertence tanto ao presente quanto o passado ou, ainda retomando a idéia kantiana de 'coisa em si', verdade atemporal. Ogden escreve: "As idéias que são articuladas são formulações da estrutura da experiência humana, uma estrutura, um conjunto de verdades que a psicanálise e outros tentam descrever, mas certamente não criar" (Ogden, 2003, p.595). 0 paradoxo a ser explorado pelo autor é o de que verdades emocionais humanas são universais mas idiossincráticas, e também são atemporais, mas relativas a um dado momento da vida do indivíduo. 
Ainda citando Thomas Ogden (2003), a experiência emocional humana tem uma realidade, uma verdade, que independe de formulações que o analista ou o paciente imponham. A idéia de verdade que independe do observador, remete Ogden à noção de verdade na ciência. A psicanálise, por exemplo, antes de Freud, compõe um conjunto de pensamentos verdadeiros à espera de um pensador para pensá-los, a verdade é oposta à criação, tem o caráter de descoberta. A psicanálise não foi inventada por Freud, assim como o sistema solar não foi inventado por Copérnico. Segundo Bion, o mecanismo pelo qual se descobrem grandes sistemas de pensamento depende da relação continente-conteúdo. Bion descreve uma disponibilidade que devemos ter para que um pensamento sem pensador se aloje em algum lugar, dentro dos limites de nossa capacidade. Pode haver um continente `a procura de realização, mas pode haver uma realização `a procura de um continente. Segundo Sandler, "há fatos reais que Kant chamaria de noumena e Bion de "O", que existem e estão `a espera de que um pensador as pense” (Sandler, 2000, p.88).

Para Bion, apenas a mentira necessita de um pensador para criá-la. 0 analista quando faz uma interpretação, dá forma verbal à experiência que antes era não-verbal e inconsciente. 0 mais importante que o analista deixa ou o resultado das interpretações não são, portanto, as identificações do paciente para com ele como pessoa, mas traços de uma experiência, novo uso psicológico daquilo que o analista tem dito, tem feito e tem sido. Nesse sentido, Grotstein afirma: “Transcendência é o 'Outro'” (Grotstein, 2003, p.21). Porém, parece difícil discriminar autorias e origens de afetos quando estamos mergulhados no Outro.

Por fim, graças à separação do modelo médico, a Psicanálise se desenvolveu com corpo autônomo, apesar das várias vertentes. Alguns autores têm ressaltado o fato de que, porém, um nova psicanálise deve dar conta das patologias que trazem em si questões sobre o "aquém da representação", como as patologias psicossomáticas, ou as estruturas que 
manifestam menos consistência subjetiva, como borderlines, adesivas e autistas. Segundo Mezan “esta tendência não é nova na Psicanálise: o que talvez o seja é o instrumental teórico e clínico desenvolvido para investigar e eventualmente tratar estas condições" (Mezan, 1997).

No tópico a seguir abordaremos a fenomenologia de Husserl e seus estudos sobre a intersubjetividade e a fenomenologia da percepção, de Merleau-Ponty. 


\section{II.2. A produção de conhecimento na fenomenologia}

A fenomenologia elaborada por Edmund Husserl (1859-1938) se inicia (Investigações lógicas, 1901) como uma crítica ao psicologismo, que não consegue resolver o problema do conhecimento, ou, colocado de outra maneira, o problema do sujeito cognoscente. Critica o naturalismo (do qual o psicologismo é um caso particular) devido `as suas consequências, ou seja, a fundamentação da consciência na única realidade que seria a Natureza, tornando-a expressão vaga de eventos cerebrais sob a ação causal exercida por objetos físicos exteriores. Afirma então o psíquico como diverso da materalidade, dizendoo fenômeno e que, na sua estrutura imanente, revela-se como algo que ultrapassa o empírico. A estrutura da consciência é intencionalidade, ou seja, toda consciência é "consciência de".

As leis do conhecimento verdadeiro devem ser encontradas numa região de a priori, ou esfera de idealidades puras. 0 filósofo (Investigações lógicas, 1901), antes da formulação do seu conceito de corporalidade, parte de um conceito de unidade da experiência como um fluxo atual do $\mathrm{Eu}$, mas como uma relação intencional. Apesar de reconhecer experiências não intencionais, estas são apenas material para unidade de significado, e em Husserl a experiência é o nome compreensível para todos os atos de consciência que são essencialmente intencionalidade.. O "objeto" da consciência, como "fenômeno", se restringe ao âmbito imanente da idéia. Porém, a intencionalidade aparece apenas com a epochè, ou redução fenomenológica, operação pela qual a atitude natural do mundo exterior é posta entre parênteses, ou a crença no mundo como se vê é temporariamente suspensa, para que seja possível a investigacão da própria consciência. A redução, ou a ausência de preconceitos possibilita a busca do significado ideal, ou essências, e mediante sucessivas 
reduções ou pré-percepções, se apresenta a intencionalidade e seus objetos. Ou seja, mediante sucessivas reduções é possível um contato direto com a essência das coisas. A subjectividade transcendental, portanto, é a observação atenta da consciência. 0 cubo percebido pode ser objeto de muitas percepções diferentes, porém o cubo pensado pode ser definido geometricamente. Porém, cada ato da consciência se apresenta como absoluto. Portanto, embora cada noesis e cada noema sejam parciais, são vividos como totalidades. 0 conceito ou idéia é a apreensão da unidade imanente do significado e a superação da infinidade de perspectivas (Husserl, 1980).

Para que se compreenda como o outro é percebido pelo Eu em Husserl, devemos incluir o conceito de unidade estática, onde o pensamento que confere a significação é fundado na "intuição" e se relaciona por meio dela, a seu objeto. A intuição contém em si as antigas categorias de conhecimento, como a sensibilidade e entendimento. Os conceitos de significação e intuição podem ser compreendidos quando se recorre aos fenômenos do preenchimento. 0 preenchimento definitivo representa um ideal de perfeição para além dos limites da sensibilidade. "O sentido estrito de evidência, na crítica do conhecimento, refere-se exclusivamente a esta meta única e insuperável, ao ato dessa síntese de preenchimento, a mais perfeita de todas, que dá `a intenção, por exemplo, ’a intenção do juízo, a absoluta plenitude de conteúdo, a plenitude do próprio objeto. 0 objeto não é meramente visado, mas, em vez disso, ele é dado, no sentido mais estrito, tal como é visado, e unido ao visar." Husserl se refere a uma síntese identificante como um ato objetificante, sendo sua realização o ser no sentido da verdade, ou verdade. A verdade é diretamente dada `a intuição e à apreensão. "Se nos ativermos inicialmente ao conceito de verdade que acabamos de indicar, a verdade, enquanto correlato de um ato identificante, é um estado de coisas, e, enquanto correlato de uma identificação por recobrimento, uma identidade: a plena concordância entre o visado e o dado como tal" (Husserl, 1980, p.94) A verdade ainda 
pode ser de essência cognitiva, e ao invés de objetal é a idéia que pertence `a forma do ato" (p.94) A verdade, em Husserl depende da idéia de adequação, ou ainda, como "tudo aquilo que é adequadamente perceptível tendo uma relação indeterminada a uma intenção qualquer que, por seu intermédio poderá tornar-se verdadeira (adequadamente preenchida)." (...) "O conceito mais restrito de verdade seria limitado `a adequação ideal de um ato relacionante `a correspondente percepção adequada de um estado de coisas; do mesmo modo, o conceito mais restrito de ser diria respeito ao ser de objetos absolutos e o distinguiria do "existir" dos estados de coisas." (Husserl, 1980, p.96)

“Algo semelhante vale para o ideal correlato de imperfeição, portanto, para o caso do absurdo e, com respeito ao "conflito" e ao não ser nele vivido, para o caso da inverdade." (Husserl, 1980, p.10)

Em todos enunciados que exprimem uma intuição chegamos finalmente aos últimos elementos, elementos materiais, ou, melhor definido, matéria intencional que estão presentes nos termos que se preenchem na intuição e diferem da forma. Em Husserl, a matéria é matéria intencional, pois que se apresenta apenas no ato intencional, a percepção é apenas interna, pois que se refere `a própria consciência, o sentido, da mesma forma é usualmente interno, e a intuição sensível é uma maneira mais ampla de falar de sensibilidade, na qual a palavra ser não encontra nenhum correlato possível. Por fim, Husserl (em "A defesa da empatia" elaborada na 5a Meditação Cartesiana) está interessado na experiência que posso ter do outro, e o problema do conhecimento do outro é o problema da constituição em mim deste objecto singular que é outro-eu. O conhecimento do outro em mim se apresenta como intersubjectivo e Husserl entende o outro por analogia, ou seja, o outro, primeiro em si é outro eu. Na empatia é possível a apresentação do outro, mas como no cubo, não sua 'presentação', o outro é outro porque suas vivências não podem ser dadas de forma original. A comunidade de nômadas formada pelos vários 
Eus constitui um só e mesmo mundo da minha experiência do outro. 0 sujeito encontra-se, pela constituição do outro, fazendo parte de uma comunidade de sujeitos.

Por fim, as percepções singulares do fluxo são unidas continuamente, e por esta continuidade dá-se a unidade de identificação na unidade fenomenológica. 0 ato de identificação, por outro lado, é uma consciência de objetividade que faz aparecer um novo objeto, que mantém uma relação com suas partes e se dá como uma unidade abrangente de ato. Há um paralelismo entre percepção e afiguração.

\section{II.2.1. Maurice Merleau-Ponty}

Sobre a intersubjetividade em Husserl, Merleau-Ponty afirma que pela minha reflexão descubro não apenas a mim mesmo, mas também um espectador estrangeiro (o Cogito me revela em situação), um tipo de fraqueza interna que me impede de ser apenas indivíduo "e me expõe ao olhar dos outros como um homem entre os homens, ou pelo menos uma consciência entre as consciências". (Merlau-Ponty, 1994, p.09) Porém MerleauPonty inclui o conceito de intencionalidade e mantém a crítica elaborada por Husserl `a filosofia Kantiana, de ter tornado o mundo imanente ao sujeito, ao invés de admirar-se e conceber o sujeito como transcendência em direção ao mundo. "Trata-se de reconhecer a própria consciência como um projeto de mundo, destinada a um mundo que ela não abarca nem possui, mas em direção ao qual ela não cessa de se dirigir" (Idem, p.15). Para MerleauPonty deve-se diferenciar o contato criador com o mundo, de conhecimento do mundo. 0 verdadeiro conhecimento parte deste contato criativo no qual o gesto natural se manifesta e difere completamente de um mundo separado por categorias racionais com o qual me relaciono pelo pensamento. Não é possível prescindir do imediatismo da experiência de compreensão que ocorre quando me coloco frente ao outro. 
Esta instância pré-reflexiva é tema do trabalho de Merleau-Ponty. A fenomenologia da existência de Merleau-Ponty só é acessível e se deixa reconhecer a um método que trata de descrever diretamente nossa experiência, sem recorrer a um sistema causalista, mas introduzindo a 'motivação'. Como veremos, o ato de ligação é o fundamento do ligado. Porém: "As imagens que o instinto projeta diante de si, aquelas que a tradição recria em cada geração, ou simplesmente os sonhos se apresentando primeiramente com direitos iguais às percepções propriamente ditas, e a percepção verdadeira atual e explícita, distinguem-se pouco a pouco dos fantasmas por um trabalho crítico (...) É ora a aderência do percebido ao seu contexto e como que sua viscosidade, ora a presença nele de um indeterminado positivo, que impedem os conjuntos espaciais, temporais e numéricos de se articularem em termos manejáveis, distintos, identificáveis. E é este domínio pré-objetivo que precisamos explorar em nós mesmos se queremos compreender o sentir". (Idem, p.34)

O primeiro conceito a ser desconstruído pela contribuição da fenomenologia da existência de Merleau-Ponty é o de "sistema sensorial" que decorre do que designou como 'sentido' em termos clássicos e inscreve-se na tradição da psicologia experimental. 0 sensível seria o que se apreende pelos sentidos; estudos fisiológicos tem como objeto as "condições objetivas" da qual a apreensão depende. Merleau-Ponty tem argumentos contra a idéia da objetividade do "sentir", demonstrando que nossa percepção se dá quando estamos lançados e portanto sempre tem significado. A ambiguidade pertence naturalmente `a experiência e o estudo fisiológico do nosso sistema sensorial não se relaciona com a experiência em si, antes, lida com premissas ingênuas e elementos sensoriais inexistentes. Seu conceito de sensação é alternativa ao conceito clássico de sensação do empirismo no qual a consciência é definida como impressão. Um ser que poderia sentir no sentido de coincidir totalmente com a impressão ou com a qualidade, não poderia ter outro modo de conhecimento. 0 empirismo parte da premissa de um mundo 
objetivo que se relaciona com um Eu, também objeto do mundo, por meio de órgãos do sentido: estímulos são conduzidos aos respectivos centros decodificadores aonde mensagens do mundo são associadas “de modo a produzir em nós o texto original”( Idem, p.28). Portanto, a hipótese empirista supõe uma correspondência entre estímulo e percepção elementar. Seus argumentos demonstram que esta correspondência não existe de fato.

Dito de outra forma: "A qualidade determinada, pela qual o empirismo queria definir a sensação, é um objeto, não um elemento da consciência, e é o objeto tardio de uma consciência científica". Merleau-Ponty demonstra que o próprio cientista deve abandonar a premissa realista, deve "aprender a criticar a idéia de um mundo exterior em si" que prejudica o desenvolvimento da ciência. "É inevitável que em seu esforço geral de objetivação, a ciência pretenda representar o organismo humano como um sistema físico em presença de estímulos definidos eles mesmos por suas propriedades físico-químicas, que procure reconstruir sobre esta base a percepção efetiva, e fechar o ciclo do conhecimento científico descobrindo as leis segundo as quais se produz o próprio conhecimento, fundando uma cieencia objetiva da subjetividade. Mas também é inevitável que essa tentativa fracasse" (Idem, p.32), pois a ciência só consegue construir uma "aparência de subjetividade" - introduz sensações que são coisas onde a experiência mostra que já existem conjuntos significativos.

A percepção se diferencia da sensação. A psicologia se autoriza `a distinguir na percepção uma camada de impressões denominando-as sensações. Ele defende que no exemplo da relação figura-fundo, a percepção elementar já está carregada de um sentido. 0 "algo" perceptivo faz sempre parte de um "campo": este vermelho, elemento de uma configuracão espacial pois perpassado de sombras, não seria o mesmo se não fosse o "vermelho lanoso" de um tapete. "A análise descobre portanto, em cada qualidade, 
significações que a habitam" (Idem, p.25). 0 puro sentir, assim como o puro vermelho não está disponível para que se possa discriminar o puro sentir. Existem duas maneiras de se enganar sobre a qualidade: (a) fazer dela um elemento da consciência quando ela é objeto para consciência ou tratá-la como uma "impressão muda" quando ela tem sempre um sentido; (b) tomar o mundo em si como algo determinado, ou seja, a despeito do que seria o 'mundo objetivo' ou a despeito da percepção que inclui a "ambiguidade" como um fenômeno positivo - atmosfera na qual se apresenta a qualidade. Se nos voltarmos para a experiência perceptiva percebemos que a ambiguidade pertence ao fenômeno e que a teoria da sensação, por outro lado, constrói objetos limpos de todo equívoco, que são um "ideal de conhecimento" - a grandeza aparente de um objeto varia conforme sua distância aparente, a cor aparente com a lembrança que dela temos: o sensível não pode ser definido como o efeito imediato de um estímulo exterior. 0 exemplo apresentado por MerleauPonty é a ilusão de Muller-Lyer, de duas retas que tem o mesmo comprimento mas são identificadas como sendo uma menor que a outra. Ele afirma que esta diferença apenas existe quando revelada por uma percepção analítica, um raciocínio que compara uma coisa com outra coisa. Ou seja, as retas não são nem iguais nem desiguais - na percepção cada uma delas é uma, pertence a um universo separado.

Para Merleau-Ponty, um sensível que vai ser sentido apresenta ao meu corpo uma espécie de problema confuso: é precise que eu encontre a atitude que vai lhe dar meio de determinar-se, ou que eu sincronize com o sensível. "Aquele que sente e o sensível não estão um diante do outro como dois meios exteriores, e a sensação não é uma invasão do sensível naquele que sente. É meu olhar que subentende a cor, é o movimento de minha mão que subentende a forma do objeto, ou antes meu olhar acopla-se ao duro e ao mole, e nessa troca entre sujeito da sensação e o sensível não se pode dizer que um aja e o outro 
padeça, que um dê sentido ao outro" (Idem, p.288). Assim, ele define a sensação como coexistência ou comunhão.

\section{II.2.2. Emmanuel Levinas e Platão}

Levinas considera que Husserl se insere no pensamento da modernidade, no qual o outro é dentro da analogia ou o que Levinas denomina o "Mesmo". A crítica de Levinas segue a desenvolvida por Heidegger. No sentido ontológico, simpatia ou empatia não são considerados virtudes ou capacidades, mas significam a própria condição do ser-aí, termo apresentado por Heidegger e aceito por Merleau-Ponty. Heidegger descreve uma abertura originária de compreensão, na qual o ser-aí está imerso. Porém, também na filosofia de Heidegger, Levinas não encontra a possibilidade de afirmar o outro. A estrutura existencial do ser-aí permanece fechada em seu próprio mundo, e a possibilidade da intersubjetividade resta como uma promessa não cumprida. A passagem de Levinas sobre o utopismo de Ernst Bloch baseado na filosofia heideggeriana, porém nos serve para análise. "Na obscuridade da pura facticidade, no deserto do ser e sua indeterminação em que é jogado o sujeito, insere-se a esperança (...) 0 homem, no seu desamparo, não está ainda no mundo!" .

A proximidade não é a proximidade física, a contiguidade, a ocupação de um mesmo espaço ao alcance do olhar ou da mão - já que toda a proximidade pressupõe sempre, de uma forma ou outra, a proximidade do Próximo, a "humanidade".

A proximidade, o contacto com Outrem não é "fusão" entre o Eu e o Outro, antes pressupõe quer a não anulação da alteridade do Outro quer a não supressão do Eu no Outro. Se a proximidade é "fruir e sofrer pelo outro", vulnerabilidade e passividade, então “o ato de falar é passividade da passividade", implica "a veracidadee a sinceridade que a troca de informações - interpretação e decodificação de signos. 
A idéia de verdade em Levinas mantém um diálogo com Platão. No texto "Sofista" entendemos: que a imitação decorrem do não-ser. Os sofistas são caçadores, tendo como arte a aquisição. Na própria caça (homens, animais domésticos), distinguem-se duas caças: a caça violenta (rapina, a caça ao escravo, a tirania, guerras) e a arte de persuasão (razões jurídicas, a oratória pública e as conversas privadas), que, por sua vez, pode se dirigir ao público ou a indivíduos. A arte do amor, seria uma espécie distinta. Na caça interesseira há uma arte que consiste em conviver a custa de favores, não procurando outro ganho do que a preopria subsistência, e com o pretexto de ensinar. Portanto, na caça que persegue os jovens ricos e de alta sociedade, devemos chamar de sofística.

A segunda definição de sofista é a de o comerciante em ciências, ou o que realiza a importação por atacado das técnicas. Ou seja, outro simulacro apresenta-se na troca artigos destinados `a alma que se transportam e vendem, `a aqueles que, de cidade em cidade, e pela arte da exibição vende as ciências por atacado, trocando-as por dinheiro, são também denominados sofistas, são os que negociam discursos e ensinos relativos ’as virtudes. Divide inicialmente a luta em duas partes: combate (se realiza corpo a corpo) e rivalidade (aquele que se opõe argumentos contra argumentos) como a contestação conduzida com arte, e relativa ao justo em si ou ao injusto em si (erística). Esta prática pode descambar para a tagarelice, caso não dê nenhum prazer aos ouvintes. Aquele que recebe dinheiro por disputas privadas, novamente é o sofista. 0 sofista é "animal variado e diverso", e como afirma o Estrangeiro: "não o apanharás com uma só mão". Ensinam eles a discussão das coisas terrenas e divinas que estão escondidas das vistas do vulgo, sabem qualquer questão geral do devir ou do ser, são bons discutidores das leis e das coisas políticas, contradizem especialistas das artes (como exercícios físicos e outras artes), mantém uma aptidão para discutir seja o que for . Por fim, o estrangeiro pergunta: é possível que um homem saiba tudo? 
Porém, os que os procuram o fazem voluntariamente. Dão portanto aos seus discípulos a impressão de serem oniscientes, trazem apenas uma falsa aparência de ciência universal. Quando se afirma que tudo se sabe e que tudo se ensinará a outrem, não seria o caso de pensar que se trata de uma brincadeira? Pergunta o estrangeiro: " ora, conheces alguma forma de brincadeira mais sábia e mais graciosa do que a mimética?" Seu interlocutor afirma ser esta a (brincadeira) mais complexa e mais diversa que existe( Os Sofista, p.151). 0 estrangeiro responde: “ Assim, o homem que se julgasse capaz, por uma única arte, de tudo produzir, como sabemos, não fabricaria, afinal, senão imitações e homônimos das realidades. Hábil na sua técnica de pintar, ele poderá, exibindo de longe os seus detalhes, aos mais ingênuos meninos, dar-lhes a ilusão de que poderá igualmente criar a verdadeira realidade, e tudo o que quiser fazer." (Idem, p. 152) . 0 argumento segue afrimando que também o discurso permite uma técnica por meio da qual se poderá levar aos ouvidos palavras mágicas, que ainda que separadas por longa distância da verdade, dão a ilusão, estas ficções verbais, de ser verdadeiro tudo o que ouvem. Por fim, o sofista é descrito como um mágico que somente sabe imitar as realidades. Prosseguindo na perseguicão ao sofista, o Estrangeiro descreve duas formas de mimética: (1) a arte de copiar o objeto (2) arte do simulacro que simula a cópia e gera simulacros. Portanto, “mostrar e parecer sem ser, dizer algo sem dizer com verdade, são maneiras que trazem grandes dificuldades, tanto hoje como ontem e sempre". (Idem, p.154)

Finalmente, Platão nos apresenta aquilo de grande importância para desenvolvermos um pensamento próprio sobre a imitação. "Que modo encontrar, na realidade, para dizer ou pensar que o falso é real sem que, já ao proferi-lo, nos encontremos enredados na contradição?" 0 falso pressupõe o não-ser como ser. "Jamais obrigarás os não-seres a ser; Antes, afasta teu pensamento desse caminho de investigação". 
E se é verdade que a sensibilidade, ou sentido, provém do rosto do Outro, este é, essencialmente, palavra. Compreende-se assim que o que está em jogo, no aceder ao rosto do outro, não é o olhar. Mesmo quando do olhar se depende, é um olhar "no sentido de, por assim dizer, escutar o rosto" o contacto, a proximidade , ou seja, o "tato" torna-se ouvido. 


\section{II.3. A produção de conhecimento na neuropsicologia}

O lugar epistemológico privilegiado na neurociência é o campo da consciência e seus derivados constitutivos. A neuropsicologia moderna foi escolhida como referencial dentro da neurociência que recentemente dividiu-se em social, afetiva e cognitiva. Como veremos, a neuropsicologia moderna desenvolveu um novo paradigma e não exige que sejam separados os aspectos cognitivos, afetivos e sociais.

Para Aleksander Romanovich Luria, psicólogo russo, apontado como fundador da neuropsicologia moderna, o sistema primário denominado como sistema reticular ascendente, dá tônus e modula estados da consciência, além de regular estados emocionais que antecedem aos processos mnésticos e de pensamento. A consciência é o grande território onde as funções psíquicas repousam, diferentemente do pensamento freudiano, que pressupõe um campo fundamental baseado no desconhecido, nos impulsos e desejos inconscientes e outros mecanismos constitutivos do sujeito que o expulsam, por assim dizer, do centro da sua vida, deixando-o a mercê do desconhecido.

A epistemologia da neurociência parte de um realismo empirista que se distancia também da fenomenologia, na qual uma consciência mais ou menos solipsista, dependendo da vertente fenomenológica, dirige-se ao mundo.

\section{II.3.1. Introducão `a Neuropsicologia moderna: conceito de sistema}

Neste trabalho, a forma de análise dos resultados de estudos em neuroimagem segue a premissa sistêmica de organização das funções cerebrais, proposta por Luria. A. R. Luria, neurologista e psicólogo denominou de 'psicologia científica moderna', “uma disciplina cujo propósito seria descrever a estrutura da atividade humana e explorar em profundidade a estrutura funcional de percepção e memória, de atividade intelectual e fala, 
de movimento e ação, e sua formação durante a ontogênese". As diversas funções neuropsicológicas organizam-se sistemicamente, ou seja, as formas de atividade mental, chamadas 'complexas' ou 'superiores', dependem da atividade simultânea de diversas regiões do sistema nervoso central, situadas próximas ou distantes entre si, distribuídas em ambos os hemisférios cerebrais (Simone, 2003).

Luria, em Os fundamentos de neuropsicologia (1973), afirma: "enquanto a visão mecanicista da localização direta de processos mentais em áreas circunscritas do cérebro levou a um beco sem saída, as idéias "integrais" (ou, como elas às vezes são chamadas, "noéticas") dos processos mentais claramente não puderam prover a base para pesquisa ulterior; elas ou preservaram idéias obsoletas de separação da vida "espiritual" do homem e da impossibilidade, em princípio, de descobrir a sua base material, ou reviveram idéias igualmente obsoletas do cérebro como uma massa nervosa primitiva, não diferenciada" (Luria, 1973, p.11). Esta crise vivida pela ciência forçou a busca de um novo caminho de investigação, que parte da natureza sócio-histórica da atividade consciente humana e de sua estrutura complexa e hierárquica.

A neuropsicologia se constituiu então como um novo caminho de investigação, demonstrando a atividade de sistemas de áreas cerebrais, que embora frequentemente se situem distantes umas das outras, funcionam em concerto. Cada uma delas pode desempenhar um papel específico que depende da localização e da sua especificidade neurofisiológica. Segundo sua contribuição, a tarefa fundamental da neuropsicologia não é a de localizar diversos processos psicológicos superiores em áreas do córtex, mas determinar, mediante uma análise cuidadosa, quais regiões do cérebro, ao operar em conjunto, efetivam atividades mentais complexas. Além disso, estuda como cada uma dessas áreas se relacionam entre si nos vários estágios do desenvolvimento. 
Desta forma, o sintoma ou perda de uma dada função particular não evidencia o lócus da função neuropsicológica (avaliada por meio de testes neuropsicológicos), pois a lesão em cada uma das zonas ou áreas do sistema funcional pode acarretar a desintegração de todo o sistema. Sua forma de trabalhar tem pressupostos da matriz funcionalista e organicista da psicologia baseando-se na premissa da incompatibilidade funcional de determinado circuito cerebral no processo adaptativo da espécie como determinante da modelagem neuroanátomo funcional, sendo este processo de adaptação histórico-social.

Luria descreveu como lei primeira da neuropsicologia algo de deve surpreender aos psicanalistas que temem 'a realidade' do cérebro: qualquer atribuição de localização diz respeito a um circuito neuroanátomo funcional que apesar de manter epicentros únicos, variam segundo o indivíduo. Portanto, a neuropsicologia demonstra que não respondemos ao que foi denominado como 'demandas do ambiente' de forma padronizada. Considero importante me deter no conceito de localização funcional descrito por Luria, para auxiliar na compreensão desta lei do funcionamento do encéfalo.

O conceito de 'função neuropsicológica' foi inspirado na função (respiratória, digestiva, etc.) exercida por um tecido particular, mas não limitado a ele. 0 sistema funcional inclui partes situadas em diversos níveis do aparelho para realizar uma tarefa invariável. A localização da função cerebral complexa é 'dinâmica', ou seja, nunca permanece estática, pois se altera durante a ontogênese (de forma essencial) e durante a vida adulta. Luria (1979) destaca as observações feitas pelo psicólogo soviético L. S. Vygotski, segundo as quais os processos psíquicos superiores tem gênese sócio-histórica, ou seja, apóiam-se em meios auxiliares com estrutura social definida. As conexões funcionais entre regiões do encéfalo se estabelecem à medida que o 'interpsicológico' ou diversas formas de organização extracortical (no mundo, com as coisas) se converte em sistema 'intrapsicológico', regulador das funções mentais. A experiência da criança com o 
outro, a utilização de instrumentos e o processo de aquisição de linguagem maturam e conectam diversas regiões cerebrais, promovendo o que ele denominou de 'organização interfuncional'.

A neuropsicologia está historicamente atrelada à neurologia clínica. Temos porém que mencionar o fato de que Luria, em 1922, foi atraído para a psicanálise, que segundo sua afirmação era o "único ramo da psicologia que estava solidamente arraigado na ciência materialista" e porque seu estudo era sobre a experiência viva de seres humanos reais (Kaplan-Solms e Solms, 2005). Porém, em 1930, Luria abandona publicamente a psicanálise, pedindo para deixar suas obrigações na Sociedade Psicanalítica Russa, sendo que menos de um mês antes havia apresentado uma discussão sobre a metapsicologia freudiana. Segundo Solms and Kaplan-Solms (2005), e diversos outros pesquisadores da obra de Luria, ele abandonou a psicanálise por questões políticas e ideológicas. De acordo com o partido stalinista daquela época, produziu um artigo no qual apresentava a psicanálise como uma "teoria falsa", chegando a afirmar que ela "biologizara o estado consciente complexo, historicamente determinado, do ser humano" (in Solms and KaplanSolms, 2005, p.47). A neuropsicologia desenvolvida por Luria pós 1930, demonstra que a dívida para com a psicanálise foi apenas "escondida sob camadas de verborréia ideológica" (Kozulin, 1984, p.1 in Solms and Kaplan-Solms, 2005, p.49).

Seu método de trabalho baseado em casos únicos foi caracterizada por ele em sua autobiografia como filiada ’a tradição clínico-descritiva da neurologia comportamental clássica. Luria desenvolveu uma obra com várias posições teóricas, mas sempre deu grande ênfase `a observação e ao pensamento provindo da clínica, e, em segundo plano `a instrumentação da medicina. A neuropsicologia de Luria descreve quadros clínicos avaliados por testagem desenvolvida por uma meticulosa pesquisa que associava descrição de casos de pacientes e localidade das lesões cerebrais (por análise postmortem ou 
intervenções neurocirúrgicas). Desde meados dos anos 70, porém, a neuropsicologia tornou-se uma forte aliada de novas técnicas de imageamento do encéfalo, restringindo sua característica fenomenológica (descritiva), baseada em estudos de caso. Com o advento da neuropsicologia cognitiva, inferências sobre a arquitetura neuroanátomo-funcional de funções cognitivas que frequentemente desconsideram elementos afetivos, estão fortemente fundadas em técnicas de neuroimagem.

II.3.2. Uma breve consideração sobre o uso das técnicas de neuroimagem

A meta da neurociência é estabelecer as relações entre estrutura e função no encéfalo, por meio de técnicas diversas, como a neuroimagem funcional. A política de produção acadêmica atual tem valorizado cada vez mais modelos científicos baseados na tecnologia. Com a tecnologia disponível atualmente, especialmente com a RMf (ressonância magnética funcional) temos possibilidade de mapearmos as regiões do encéfalo que participam quando se requer a compreensão da intenção de personagens filmados, fotografados ou ainda desenhados em forma de figuras que se ordenam segundo uma suposta lógica intencional. Estudos com ressonância magnética funcional, por exemplo, apresentam resultados quando dois sujeitos interagem e o nível de vinculação (attachment) dos casais e se demonstra por maior ou menor atividade da amígdala. Ou seja, a RMf tem pode com gostar mais ou menos de determinada pessoa ou ter mais ou menos afinidade. Caso este tipo de pesquisa prosperasse, serviria como pré-teste para as vendas de uma moderníssima agência de matrimônios... Nos parece um risco, que em um futuro próximo tenhamos que utilizar medidas de aparelhos desenvolvidos pela biomedicina para nos certificar do que de fato, se gosta, ou aquilo que, de fato, faz bem ao ser humano.

Nesse sentido, merece uma análise mais aprofundada o uso que tem sido feito de estudos sobre mapas corticais funcionais como servir de instrumento de validação de 
práticas psicológicas, antes e depois de diversos tipos de psicoterapia, psicanálise, reabilitação neuropsicológica e outros tratamentos, como farmacológicos. Na psicologia temos que esclarecer quais são os limites da tecnologia e que esperança é colocada na ciência. Mais especificamente, consideramos importante que se esclareçam quais são os benefícios e os malefícios do uso indiscriminado de teorias baseadas em resultados provenientes de aparelhos de medição ou tecnológicos.

Autores atuais (Feemberg, 1999) argumentam que as tecnologias são construções sociais que desempenham um papel central nos próprios processos sociais - demarcam posições e condutas e geram problemas sociais, ambientais, de acesso a bens e serviço. Heidegger coloca o projeto científico no lugar da vontade de poder, ou seja, a essência da técnica, ou a dimensão técnica da inserção humana na natureza foi usurpada as coisas reduzidas a entes oferecidos `a dominação do olhar. "A física moderna não é uma física experimental porque dispõe de aparelhos para interrogar a natureza. É o contrário: porque a física - e isto já é pura teoria - intima a natureza a se mostrar como um complexo calculável e predizível de forças é que a experimentação é obrigada a interrogá-la, a fim de que se saiba se e como a natureza assim intimidada responde ao chamamento" (Sobre a técnica). Contra a tendência da ciência contemporânea de transformar técnica em tecnologia, demandando grandes somas do poder público e de empresas, com retorno restrito aos próprios agentes financiadores, e sem controle de danos a longo prazo sobre a sociedade e sobre a natureza, considero que o papel da tecnologia na sociedade de hoje e na produção de conhecimento deveria ser tratada em termos sociológicos.

Feemberg propõe que é possível a tradução entre uma demanda pública, baseada em um conceito de direitos humanos se dar em uma especificação técnica. 0 conceito de 'código técnico' “é o modelo do conteúdo vinculado, de um lado, no discurso dos movimentos sociais e, de outro, nas especificações técnicas" (Feemberg, 2009). Ele ressalta 
que os códigos técnicos dominantes foram desenvolvidos nos países avançados e são importados, tecnologia e disciplinas técnicas, pelos países em desenvolvimento.

Contra o a crença da neutralidade científica sabemos que a ciência não está isenta de absorver e criar as linhas de força do seu tempo, ou de cumprir o ideal delegado pela sociedade na qual e pela qual é produzida. 0 que temos presenciado é a necessidade de redefinir enquanto sociedade o que nos move, termos novos ideais. Nesse sentido, da mesma forma que os analistas se vêem sempre `as voltas com a questão do reconhecimento do seu trabalho frente a uma sociedade que corre o risco da medicalização abusiva, os estudos em neurociências também deveriam passar por um crivo da sociedade em termos de prioridades, e não somente da comunidade científica, muitas vezes cega para questões sociais relevantes.

Outra questão importante é sobre que liberdade o desenvolvimento da tecnologia permite. A questão que fica em aberto é como permitir que o ser humano se aproprie da sua vida a ponto de se responsabilizar pelas suas escolhas.

Neste trabalho foram revisados alguns estudos de neuroimagem sobre empatia, que constituem uma vasta bibliografia.

\section{II.3.4. Neuropsicologia da emoção}

\section{II.3.4.1. O papel das emoções}

Com o artigo intitulado "O que é emoção", William James propôs, em 1884, que as emoções decorrem das reações corporais causadas por um estímulo. Este filósofo desenvolveu a tese de que da percepção de um estímulo como um urso decorrem alterações corporais como contrações no estômago, suor nas mãos, taquicardia e a sensação destas mudanças no momento da ocorrência é uma emoção, no caso o medo. Para ele as diferenças entre emoções decorreriam de diferentes sintomas fisiológicos. 
A abordagem da emoção como anterior à percepção de mudanças no organismo foi colocada em questão no início deste século por Walter Cannon (Cannon, 1939). Fisiologista, Cannon afirmou que a atuação do ramo simpático do sistema nervoso autônomo era uniforme e portanto não dependeria do estímulo emocional apresentado. Além disso, as respostas deste sistema seriam muito lentas para produzirem sensações e as emoções seriam simultâneas às reações fisiológicas.

Discussões sobre o processo emocional baseadas no conceito de sistema cerebral funcional complexo levantam a questão da independência dos processos emocionais em relação à cognição. Autores cognitivistas como Zajonc (1980) defendem o ponto de vista de que o primeiro nível de reação ao ambiente é sempre afetivo e a cognição corresponde ao raciocínio consciente sendo que fazem parte de sistemas separados e parcialmente independentes. Neuropsicólogos opõem-se a modelos que consideram emoção e cognição decorrentes de sistemas cerebrais diferentes com o argumento de que este tipo de independência é incompatível com a organização hierárquica do sistema nervoso e de que a função adaptativa que tem a emoção inclui necessariamente a cognição nos seus processos de interpretação, antecipação e solução de conflitos. De fato a solução cognitivista coloca a emoção entre a cognição e a reação fisiológica como solução para a polêmica James-Cannon. Para Schachter e Singer (1962) as reações fisiológicas que ocorrem durante a emoção nos informam sobre a presença de um estado de excitação, mas, como frisou Cannon estas respostas seriam similares e portanto não nos informariam sobre o tipo de emoção vivenciada. A especificidade da emoção seria decorrente da classificação feita por nós a partir das informações anteriormente adquiridas sobre as emoções experienciadas em diferentes contextos físicos e sociais.

A forma de acesso às emoções nas pesquisas da psicologia cognitiva é a introspecção, metodologia criticada por LeDoux (1996) devido ao caráter inconsciente dos 
processos emocionais, que caracteriza a introspecção como fonte pouco confiável na compreensão do funcionamento mental. Outra crítica deste autor referente à abordagem cognitiva é a ênfase dada aos processos cognitivos que reduz a distinção entre emoção e cognição e desconsidera aspectos que são únicos da emoção.

Na tentativa de distinguir emoção de cognição LeDoux caracterizou dois tipos de emoção, (1) as emoções básicas como inatas ou primárias, de caráter mais biológico e herdado e (2) as emoções secundárias derivadas da experiência e de característica mais social. Sobre isso este autor afirma: "Naturalmente, é fundamental entender quais são as emoções biologicamente herdadas e as socialmente construídas. Bem como determinar onde se situa a linha divisória entre elas. Parece igualmente importante definir o limite entre fenômenos mentais que são emoções e que não são" LeDoux (1996, p115).

Desenvolvendo a teoria Darwiniana de classificação geral das emoções inatas (Darwin, 1920), muitos autores elaboraram diversas classificações de emoções básicas. Izard (1977) considera a existência de 8 emoções básicas assim como Tomkins (1964) que selecionou as emoções: surpresa, interesse, alegria, raiva, medo, aversão, vergonha e angústia; Plutchik (1994) definiu como básicas 8 emoções (discordando de Tomkins em relação a 3): surpresa, alegria, raiva, medo, aversão, aceitação, tristeza e expectativa. Estes autores consideram a formação de emoções não básicas pela combinação das emoções básicas entre si. Izard (1977), por exemplo descreve a ansiedade como a combinação de medo com duas adicionais que podem ser culpa, curiosidade, vergonha, raiva ou angústia. Plutchik (1994) criou um amplo leque de combinações (díades primárias, secundárias e terciárias) em que, por exemplo, tristeza associada a raiva causa mau-humor e expectativa associada ao medo causa ansiedade.

II.3.4.2. Estudos empíricos sobre empatia 
Os estudos empíricos da psicologia sobre a empatia (que usam diversas escalas de empatia, de personalidade ou de humor) são basicamente de dois tipos: o que considera a empatia relacionada a traços de personalidade e os que elaboram modelos da empatia como estado-dependente, mais sujeita `as influências de emoções positivas e negativas, e ao "contágio emocional". Ambos consideram a importância da empatia para os relacionamentos sociais.e o sentimento de moralidade. Incluímos a Balanced Emotional Empathy Scale - BEES (BEES; Mehrabian, 1996) para descrever alguns dos itens que devem ser medidos por uma análise introspectiva. 0 sujeito deve pontuar (numa escala de $-4 \mathrm{a}+4$ ) as afirmações conforme ele é na maioria das situações, não considerando "situações específicas" ou como "gostaria de ser". Os itens a serem pontuados incluem: "Eu gosto muito e me sinto animado com finais felizes", "Seria extremamente doloroso para mim ter que dar notícias muito ruins a outra pessoa", "A tristeza de uma pessoa próxima não me influencia", "É muito bom para mim ver crianças abrindo presentes", "Eu facilmente me deixo levar pelas letras de músicas de amor", "Raramente caem lágrimas enquanto leio um livro ou assisto a um filme", "Eu tenho muito pouca simpatia por pessoas que causam suas próprias doenças sérias (ex. doença do coração, diabetes, câncer de pulmão)", "Eu não poderia assistir a uma execução", "Eu sou facilmente animado quando aqueles ao meu redor estão cheios de vida e felizes", "Me deixa triste ver alguém sendo maltratado", "Eu não capto facilmente emoções geradas por uma multidão". Segundo os autores, a Hogan's Empathy Scale mede a interação significativa entre pessoas, que requer um "esforço de vontade" na construção do ponto de vista do outro. A empatia, considerada a tendência para apreender o estado de mente ou condição do outro é um conceito central em muitas teorias sobre o comportamento social. Esta escala prediz também o pensamento moral maduro, a efetividade da terapia, o abuso infantil e a acuidade social. 
No primeiro grupo (Johnson e Cheek, 1983; Greif e Hogan, 1973) a empatia é melhor definida como uma habilidade para interagir socialmente e para "construir" o ponto de vista do Outro. Os autores caracterizam a estrutura da empatia, relacionada aos aspectos de personalidade. A empatia divide-se em fatores como: tolerância ou disposição de temperamento suave; estilo interpessoal de ascensão; atitudes sociopoliticas humanistas. A escala foi aproximada ao fator de "adequação interpessoal". Resultados que seguem a mesma linha demonstram que a empatia pode ser definida por componentes distintos como: auto-confiança social, temperamento estável (incluindo os itens amabilidade, agradabilidade), sensibilidade e não conformismo (não convencional, inovador, e politicamente liberal, preferência a siuações novas). Empatia também está relacionada com medidas como: capacidade para status, sociabilidade, presença social e auto-aceitação, mas mantém uma relação de implicação com a capacidade para pensamento independente e ação. Esta medida, por sua vez, é definida como flexibilidade mental, tolerância, eficiência intelectual, abertura psicológica.

No segundo grupo, alguns pesquisadores (Nezlek et al, 2001) partem de estudos que abordam a variabilidade diária de empatia medida por escalas como a $B E E S$, porém relacionando-as com a relação traço-estado como humor. Segundo eles, estudos que definem a empatia como e experiência que tenho do outro, ou a experiência vicária relacionam a empatia com traços de personalidade. Porém, o estudo do estado variável da empatia é importante, se definirmos a empatia como um estado, relacionado a humor e ansiedade. A empatia como estado-dependente estaria mais sujeita ’as influências de emoções positivas e negativas, ao "contágio emocional". A expressão da empatia, como sociabilidade dependeria mais de contextos sociais, ou de características de tipo estado, mais do que traço, e assim faz-se necessário definir a quais estado-dependente a empatia se refere. Correlação entre empatia e habilidade interpessoal demonstram que pessoas com 
alto nível empático tendem a ser mais agradáveis, são pais mais tolerantes, ajudam ao próximo, são mais altruístas e mais satisfeitas em seus relacionamentos românticos. Pessoas com alta capacidade empática tendem a ser mais sensíveis quanto `a estimulação social. A revisão apresenta dois grupos de resultados, um no qual estas características diferem quanto ao afeto positivo e outro grupo que relacionam a empatia com afeto negativo. A justificativa é de que nos dias que se está mais excitado (aroused) tanto positiva quanto negativamente, o afeto será mais saliente e a pessoa é mais empática. Os autores afirmam que diferenças diárias de empatia está de acordo com a "clássica dicotomia" "trabalho e amor" de Freud (eventos de aquisição e eventos sociais). Por fim, após a aplicação de escalas introspectivas e da análise de resultados, a pesquisa encontrou o resultado de que, como esperado, a empatia varia com eventos diários negativos e positivos e com humor. A relação entre empatia e o traço de ansiedade se reflete também no humor negativo, sendo a ansiedade um componente importante do humor negativo (Nezlek et al, 2001).

\section{4. Psicanálise e Neurociência : Neuropsicanálise}

Ambas, psicanálise e as neurociências, excluíram a metafísica no seu esforço para satisfazer a 'pulsão epistemofílica' que exige conhecer. Podemos pensar que a clínica psicanalítica, portanto, tem relação com as verdades empiricamente testadas pelo método científico na medida que ambas descrevem faces do "real".

Freud escreve: "até aqui deixamos ao escritor de ficção descrever-nos as condições necessárias ao amor que determinam a escolha de um objeto feita pelas pessoas e a maneira pela qual elas conduzem as exigências de sua imaginação em harmonia com a realidade. 0 escritor pode, realmente, valer-se de certas qualidades que o habilitam a realizar esta tarefa: sobretudo, de sensibilidade que lhe permite perceber os impulsos 
ocultos nas mentes de outras pessoas e de coragem para deixar que a sua própria, inconsciente, se manifeste. Há entretanto, uma circunstância que diminui o valor comprobratório do que ele tem a dizer. Os escritores estão submetidos à necessidade de criar prazer intelectual e estético, bem como certos efeitos emocionais. Por essa razão, eles não podem reproduzir a essência da realidade tal como é, senão que devem isolar partes da mesma, suprimir associações perturbadoras, reduzir o todo e completar o que falta. Esses são os privilégios do que se convencionou chamar 'licença poética'. Além disso, eles podem demonstrar apenas ligeiro interesse pela origem e pelo desenvolvimento dos estados psíquicos que descrevem em sua forma completa. Torna-se, pois, inevitável que a ciência deva, também, se preocupar com as mesmas matérias, cujo tratamento, pelos artistas, há milhares de anos, vem deleitando tanto a humanidade, muito embora seu trato seja mais tosco e proporcione menos prazer. Essas observações, esperamos, servirão para nos justificar, de modo amplo, o tratamento estritamente científico que damos ao campo do amor humano. A ciência, é, afinal, a renúncia mais completa ao princípio de prazer de que é capaz nossa atividade mental" (Freud, 1910).

Porém, a que ciência Freud se referencia neste trecho? No decorrer de sua obra, a ciência é evocada para delimitar um campo de investigação novo, objeto da psicanálise, e, mais precisamente da atividade do psicanalista. Caso seja usado o recurso das ciências naturais para fornecer à psicanálise um caráter de verdade, o método epistemológico de prova é diverso do método científico.

A diferença, de qualquer forma marcada, pode ser descrita como a clássica posição ambígua da psicologia na abordagem do indivíduo, expressa na seguinte citação: “ou bem o indivíduo é realmente único, independente e irracional, sendo, portanto, refratário às leis da ciência e da sociedade; ou bem não passa o indivíduo de uma ficção a ser desfeita, e então a psicologia será também uma ilusão transitória desfeita, e não se justifica como 
ciência independente (...) Um, objeto de uma psicologia que não é ciência; outro, objeto de uma ciência que não chega a ser psicologia" (Figueiredo, 1989, p.22). "Se as ideologias científicas do pensamento psicológico afirmam que o sujeito é tão bom como outro qualquer para o exercício do poder, e legitima a dominação com o manto idôneo da ciência, as ideologias românticas complementam: independentemente destas questiúnculas de dominação e poder, a liberdade humana é indestrutível, o indivíduo é livre e a própria escravidão é uma opção do sujeito" (Figueiredo, 1989).

Por outro lado, a revisão das práticas e saberes psicológicos (Figueiredo, 1996) situa 'as psicanálises', já com tradição nas suas diversas vertentes, inclusive no Brasil, como um lugar paradigmático de morada do homem. Isso porque a Psicanálise problematiza as suas fronteiras ao invés de excluir o diálogo, propicia o trânsito e não se estabelece rigidamente em um dos lugares disponíveis, o que impediria o contato com todos os impensáveis que se formam deste lugar (Figueiredo, 1996). Figueiredo considera que Freud, em seu texto “pré-psicanalítico” (Projeto para uma psicologia científica, 1895 In: Gabbi, ) se refere aos subterrâneos fisiológicos com a mesma exigência que aos 'avessos da consciência': “eles precisam nos ajudar a entender tanto o alcance quanto os limites do experimentável" (Figueiredo, 1996, p.32).

Como apresentamos acima, as neurociências englobam áreas de conhecimento que investigam a dinâmica do cérebro e de suas conexões com as funções mentais, tanto em ‘estado de normalidade’ como em estados patológicos. Apesar da maior parte da atividade cerebral ocorrer sem a atenção consciente, a neuropsicologia estuda e avalia as funções mentais da consciência. Seus fundamentos se encontram na crise vivida pela ciência no início do século, entre os 'localizacionistas estritos' que elaboravam mapas hipotéticos da 
superfície cortical localizando as funções mentais nos chamados 'centros' 2, e os que defendiam a natureza 'espiritual' dos processos mentais. A tarefa fundamental da neuropsicologia não é a de localizar os processos psicológicos em áreas do córtex, mas determinar, mediante uma análise cuidadosa, quais regiões do cérebro, ao operar em conjunto, efetivam atividades mentais complexas. Além disso, estuda a contribuição de cada uma dessas áreas para o sistema funcional e como elas se relacionam entre si, nos vários estágios do desenvolvimento. Sua forma de trabalhar tem pressupostos da matriz funcionalista e organicista da psicologia (Figueiredo, 1989), partindo da premissa de que a incompatibilidade funcional de determinado circuito cerebral no processo adaptativo da espécie determina a modelagem neuroanátomo funcional, sendo este processo de adaptação histórico-social.

A psicanálise serve aos psicanalistas enquanto técnica de acesso ao inconsciente para ajudar pessoas em sofrimento: “... pois não queremos ouvir do nosso paciente somente o que ele sabe e esconde dos outros; é preciso que ele nos diga também o que não sabe" (Freud in Sandler, 2003). A diferença sob certo aspecto irreconciliável destes dois campos de conhecimento tem raiz histórica, pois se inserem em matrizes de pensamento diferentes (Figueiredo, 1989), ou seja, destoam quanto aos 'interesses expressos' e quanto aos 'modelos de inteligibilidade'. A psicanálise vem atrelada ao movimento romântico que pressupõe que forças naturais, ou tendências em conflito constituem um mecanismo gerador de símbolos (os fenômenos psíquicos são totalidades expressivas a serem compreendidas e interpretadas), mas sem perder de vista sua inserção enquanto ciência natural. Nesse sentido concordo com Sandler, quando afirma que: "Freud serviu-se da

\footnotetext{
${ }^{2}$ A teoria frenológica de Franz Joseph Gall (1757-1828) pressupunha que características diversas do crânio refletiam o desenvolvimento de diversos "órgãos da mente", situados nos chamados "centros" como o "centro de amor sexual", "centro da esperança", "centro da agressividade", dentre outros. Os centros restringiam os "órgãos" do encéfalo (sede do espírito) e suas respectivas faculdades mentais. A discussão sobre os "centros" e sua especificidade foi muito intensa durante o século XIX, especialmente nos "esplêndidos anos 70" (Luria, 1974).
} 
percepção romântica do inconsciente para conceber uma imersão científica no desconhecido" (Sandler in Green, 2003, p.218).

Porém, desde seu texto 'pré-psicanalítico' (Projeto para uma psicologia científica, 1895 in Gabbi, 2003) Freud se refere aos subterrâneos fisiológicos, como afirma Figueiredo, com a mesma exigência que aos 'avessos da consciência': "eles precisam nos ajudar a entender tanto o alcance quanto os limites do experimentável" (Figueiredo, 1996, p.32). Porém, a leitura filosófica do Projeto, feita por Gabbi (2003) afirma: "Supomos que esta obra tem uma lógica interna que pode ser adequadamente descrita. Dizendo de outro modo, não aceitamos a concepção de que estaríamos diante de uma obra indefinidamente aberta em que todas as interpretações seriam possíveis e igualmente válidas. (...) $\mathrm{Na}$ verdade, reflete as tentativas de Freud para fundamentar uma clínica baseada na palavra e é extremamente útil para quem deseja conhecer como se originou a psicanálise" (Gabbi, 2003, p.08). Para Mezan (2001), o Projeto surgiu num contexto de estudo da psicopatologia da histeria, para responder à pergunta: "Por que os histéricos sofrem de reminiscências? A memória é uma função psíquica normal; trata-se de descobrir em que ela consiste e através de que processos ela se transforma" (Mezan, 2001, p. 31).

Outros pesquisadores desde a década de 70 situam esta obra no campo neuropsicológico, como o neurologista Karl Pribram (1976) que afirma que seu interesse pelo Projeto decorre de sua 'sofisticada neurofisiologia', e que, deste ponto de vista o Projeto seria uma obra neuropsicológica realizada no contexto de idéias do final do séc XIX 3.

\footnotetext{
3 "There is truly a tradition in neuropsychology, a tradition shared by Freud, which, over the past two centuries has developed a fairly valid but testable and modifiable picture of the mind/brain relationship. Much of this picture was developed in the nineteenth century and has been passed on to us in Freud's 1895 Project for a Scientific Psychology" (Annals, pg 19).
} 
Independente do propósito ${ }^{4}$ do texto, que inclui o ponto de vista biológico, mas, por exemplo, também assinala o papel do outro no desamparo inicial do ser humano, não se pode negar que seu conteúdo seja estimulante do ponto de vista neurofisiológico, ou neuropsicológico. Trechos como: “(...) impõe-se a conjectura de que os estímulos endógenos consistiriam, tanto no caso presente como na liberação sexual, em produtos químicos, cujo número pode ser considerável" (Freud, 1895 in Gabbi, 2003, p. 198). Segundo a compreensão de Gabbi (2003, nota 110, p.59) esta afirmação poderia ser traduzida por: "a sexualidade seria um composto de substâncias químicas a ser cuidadosamente manipulado de modo a impedir danos ao sistema nervoso central", elementos do funcionamento mental ainda pouco compreendidos.

Nesse sentido, Pribram afirma ter encontrado no Projeto uma teoria da motivação com base na memória, e com grande deleite pôde fundamentar a certeza de que para se fazer boa neuropsicologia não se pode excluir a subjetividade. Para citarmos um exemplo da neuropsicologia encontrada por Pribram no Projeto, Freud descreveu, em 1895 o duplo feedback entre tronco cerebral e córtex para produzir o processo atencional, necessário no teste de realidade. Por outro lado, Pribram considera que as observações clínicas de Freud nos anos posteriores permitiram desenvolver uma metapsicologia ${ }^{5}$ de forma completamente independente de qualquer modelo neurofisiológico.

Mesmo em trabalhos posteriores (Além do princípio de Prazer, 1920) encontram-se especulações, neste momento "com base em impressões derivadas de nossa experiência psicanalítica" (p.40) sobre localização cortical do sistema Pcpt.-Cs (perceptivo consciente), situado na "linha fronteiriça entre o mundo externo e o interior". No fenômeno de tornarem-se conscientes "os processos excitatórios não deixam nenhuma alteração

\footnotetext{
4 “O propósito [é] fornecer uma psicologia científica e naturalista, ou seja, expor os processos psíquicos como estados quantitativamente determinados de partes materiais capazes de serem especificadas e, com isso, torna-los intuitivos e livres de contradição" (Freud, 1895, Introdução do Projeto in Gabbi, 2003, p. 175).

5 Exposição metapsicológica: descrição de um processo psíquico em seus aspectos dinâmicos, tópicos e econômicos.
} 
permanente em seus elementos, mas exaurem-se, por assim dizer, no fenômeno de tornarem-se conscientes" (p. 41). Esta descrição está implicada em uma discussão atual sobre a percepção e consciência, como na descrição do funcionamento da chamada 'memória sensória' permanentemente em funcionamento, garantindo a persistência do estímulo em andamento e garantindo que o sistema perceptual tenha capacidade para processar os novos estímulos (inputs) (Haber, 1983).

Segundo Freud indica neste texto (1920), camadas posteriores do cérebro seriam responsáveis pela recepção da quantidade de estímulo que o primeiro sistema deixou passar, com sentimentos da série desprazer-prazer que predominam sobre todos os estímulos externos. De fato, isto se aplica à passagem de uma forma de sustentação da informação (estímulos externos) por breves períodos na consciência para a sua consolidação pela atividade de áreas do sistema límbico como hipocampo, e processo neurofisiológico denominado 'potenciação sináptica de longa duração'.

Dentre o intercâmbio possível entre as neurociências e a psicanálise, pesquisas no campo da psicobiologia como a desenvolvida por Allan N. Schore (1994) fundamenta com uma revisão monumental no campo da neurofisiologia a instauração complexa da habilidade para o bebê se relacionar com o outro com um período crítico característico, antes da instauração da linguagem. Schore se destaca dentre os autores que têm se esforçado para serem "bilíngues" em psicanálise e neurociência, exatamente por trabalhar com ordem de causalidade que parte da experiência subjetiva para a materialidade subjacente: propõe um "modelo psiconeurobiológico de ontogênese da auto-regulação emocional". Ele resume da seguinte forma a relação entre psicanálise e neurociências: "It is argued that recent advances in the interdisciplinary study of emotion show that the central role played by regulatory structures and functions represents such a contact point, and that the time is right for a rapprochement between psychoanalysis and neuroscience. Current 
knowledge of the psychobiological mechanisms by which the right hemisphere processes social and emotional information at levels beneath conscious awareness, and by which the orbital prefrontal areas regulate affect, motivation, and bodily state, allows for a deeper understanding of the "psychic structure" described by psychoanalytic metapsychology. The dynamic properties and ontogenetic characteristics of this neurobiological system have important implications for both theoretical and clinical psychoanalysis" (Schore, 1997). Para Schore, a maturação da região órbito-frontal direita depende da experiência emocional primária, do ambiente emocional estabelecido pela díade bebê-mãe que estimula e contém aspectos emocionais da criança, permitindo seu desenvolvimento socioemocional com a progressiva capacidade para lidar com relações de objetos em grau crescente de complexidade. Nesse sentido, fundamenta neurobiologicamente a instauração do ego enquanto instância que encontra sua coesão (quanto às suas fronteiras internas e externas) devido à experiência de satisfação primária. Os objetos primários pulsionalizados servem de base para todos os processos de ligação e permitem a vigência do princípio de prazer e de realidade.

Outra possibilidade da psicobiologia tem sido a chamada 'neuro-psicanálise', que surgiu com a meta de conciliar perspectivas neurocientíficas e psicanalíticas sobre a mente, 'considerando que as duas disciplinas têm se engajado na tarefa de entender as complicações do funcionamento mental, mas a partir de perspectivas completamente diversas' (Solms e Nersessian, 1999). Com o lançamento da revista Neuro-psychoanalysis an interdisciplinary journal of psychoanalysis and the neurosciences foi anunciada a proposta de comunicar aos pesquisadores de ambas as áreas matérias de interesse comum, devido ao 'avanço extraordinário' da neurociência e descobertas de interesse vital aos psicanalistas, dados que não foram incorporados à psicanálise (Solms e Nersessiam, 1999). 
Apesar do alegado 'avanço extraordinário' da neurociência, me remeto novamente a Freud para justificar a importância de se partir da clínica psicanalítica para o estudo das bases neuroanátomo-funcionais dos processos mentais: "a anatomia cerebral não tem necessidade de considerar por que, anatomicamente falando, a consciência deva alojar-se na superfície do cérebro, em vez de encontrar-se seguramente abrigada em algum lugar de seu mais íntimo interior. Talvez nós sejamos mais bem sucedidos em explicar essa situação, no caso de nosso sistema Pcpt.-Cs." (Freud, 1920, Além do princípio de prazer, p.39). Nesse sentido, entendo que Freud não deixou de ser neurologista por que no início do século XX os recursos da área médica eram escassos, mas por uma escolha epistemológica, ou seja, por que se aproximar do ser humano não pode ser feito pela via neurológica. Pribram (annals, ver data) afirma que Freud, como cientista, teve necessidade de que a psicologia fosse ciência 'in its own right', e não como uma disciplina neurológica6 .

Intercâmbios da psicanálise com as neurociências, têm causado interesse em alguns psicanalistas e psiquiatras, pela curiosidade quanto ao padrão geral de funcionamento do cérebro e da mente. André Green ao comentar de forma cuidadosa os trabalhos sobre a teoria dos afetos numa perspectiva neurocientífica (Green, 1999) diz que esta comunicação deve envolver mútua educação sobre as restrições de cada método, inclusive considerando a forma discrepante de pensar dos pesquisadores de cada um dos campos, em níveis de complexidade também diversos. Afirma que este conhecimento colocado em perspectiva pode ser uma aquisição importante, devido ao esforço enorme que não pode ser feito sem a ajuda do tempo.

Considerando, portanto, a matriz de pensamento romântico da psicanálise, mas não deixando de considerá-la uma ciência natural, podemos considerar que a psicanálise

\footnotetext{
${ }^{6}$ Segundo ele, por isso Freud não tem sido considerado no âmbito científico. "Why is Freud considered so differently than are Pavlov or Hebb? I believe the answer is simple. Pavlov and Hebb couched their neuropsychological speculations in neuroscientific terminology—voilà, they are neuroscientists. Freud, by contrast, couched his neuropsychology in psychological, subjective terms (Annals, pag 18)."
} 
problematiza as suas fronteiras e ao invés de excluir o diálogo, propicia o trânsito entre diversas disciplinas, pois não se estabelece rigidamente em um dos lugares disponíveis ${ }^{7}$ (Figueiredo, 1996). Nesse sentido, apesar das resistências que a experiência do inconsciente traz, e da própria resistência que a psicanálise possa gerar dentro da Universidade sua característica transdisciplinar pode ser bem desenvolvida dentro de um ambiente abrangente de discussão como a Universidade (Figueiredo, 1996).

Também no campo da clínica psicanalítica, alguns autores têm ressaltado o fato de que uma nova psicanálise deve dar conta das patologias que trazem em si questões sobre o “aquém da representação", como as patologias psicossomáticas, o Estas questões que envolvem a pulsão parecem constituir um tema que merece ser abordado pela neurociência. Nos remete ao problema da relação entre "qualidade" e "quantidade" mencionado por Freud no "Projeto para uma psicologia científica (1895)": "Se se retiver que nossa consciência fornece apenas qualidades, enquanto que a ciência natural só reconhece quantidades (...)" na metapsicologia a pulsão vai aparecer como um conceitolimite entre o psíquico e o corporal (Green, 1989) ou entre a territorialidade e a quantidade. A dimensão destrutivo-agressiva da pulsão de morte tem sido deixada de lado, desde que Green a definiu como uma função desobjetalizante reiterando seu aspecto de desinvestimento.

O interesse pelo fundamento neurofisiológico da mente aparece de forma ambígua na obra de Freud. Ao iniciar a descrição detalhada do aparelho psíquico da primeira tópica (Freud, 1900, p.572) o autor afirma: “o que nos é apresentado aqui é a idéia da localização psíquica. Desprezarei inteiramente o fato de que o mecanismo mental em que estamos aqui

\footnotetext{
${ }^{7}$ Figueiredo discorre claramente sobre o caráter transdisciplinar da psicanálise quando afirma que: "Temos exemplos como o de Freud, cuja formação enquanto neurologista, enquanto médico, enquanto alguém ligado ao campo da biologia, não teria sido suficiente, mas, sem dúvida, também não teria sido dispensável para as suas formulações teóricas. É claro, por outro lado, que se ele não tivesse a formação "holística", se não tivesse um conhecimento de literatura, de filosofia, de artes, se não estivesse interessado nos grandes problemas sociais, na guerra, nas diferentes expressões da cultura, a Psicanálise não existiria. Ou seja, eu diria que a Psicanálise, por natureza e nascimento, tem um caráter transdisciplinar."
} 
interessados é-nos também conhecido sob a forma de preparação anatômica e evitarei cuidadosamente a tentação de determinar a localização psíquica por qualquer modo anatômico" (Freud, 1900, p.572). Porém a tentação o acompanhou durante longos anos, tendo especulado, sempre em afirmativas que se contradizem, que a consciência se situa na corticalidade e o inconsciente possivelmente nas estruturas subcorticais. Na sua obra, muitas vezes esteve presente a referência da psicanálise como uma ciência biológica, como na descrição dos processos biológicos dos protozoários para entender as pulsões de vida e de morte ou na indicação de que a topografia destas pulsões se diferenciam. Ou seja, parece ter havido em alguns de seus textos um diálogo secreto com o Freud-neurologista. Também vale a pena atentar para passagens quando se justifica sobre o uso de termos figurativos nas especulações sobre pulsões de vida e de morte: "As deficiências de nossa posição provavelmente se desvaneceriam se nos achássemos em posição de substituir os termos psicológicos por expressões fisiológicas ou químicas. É verdade que estas também são parte de uma linguagem figurativa, mas trata-se de uma linguagem com que há muito tempo nos familiarizamos, sendo também, talvez, uma linguagem mais simples" (Freud, 1920, p.81).

Parece ser um conhecimento que encontra na Universidade ou em Institutos interdisciplinares o melhor lugar para se desenvolver, pois apesar das resistências que a experiência do inconsciente traz, e da própria resistência que a psicanálise possa gerar dentro da Universidade, Figueiredo (2001) defende que a psicanálise se constitui como uma disciplina transdisciplinar: "Temos exemplos como o de Freud, cuja formação enquanto neurologista, enquanto médico, enquanto alguém ligado ao campo da biologia, não teria sido suficiente, mas, sem dúvida, também não teria sido dispensável para as suas formulações teóricas. É claro, por outro lado, que se ele não tivesse a formação "holística", se não tivesse um conhecimento de literatura, de filosofia, de artes, se não estivesse 
interessado nos grandes problemas sociais, na guerra, nas diferentes expressões da cultura, a Psicanálise não existiria. Ou seja, eu diria que a Psicanálise, por natureza e nascimento, tem um caráter transdisciplinar. Isto não quer dizer que ela seja um amálgama, uma mistura das várias coisas. Ela tem a sua singularidade, mas é uma singularidade que se construiu exatamente nesse lugar às vezes muito difícil, muito problemático em termos epistemológicos, e muito denso, que é o de uma acentuada transdisciplinaridade. É nesta medida que eu penso que uma das coisas que, às vezes, os Institutos de formação, as Sociedades Psicanalíticas não conseguem oferecer é... Uma formação em Psicanálise. É lógico que o comum dos psicanalistas não vai ter nem precisa ter a cultura de Freud, ou de outros grandes nomes da Psicanálise, como, por exemplo, Bion, que ia da matemática para a filosofia oriental, para a literatura e assim por diante. Estes, contudo, são os grandes criadores, indispensáveis aos desenvolvimentos científicos e técnicos da disciplina. Mas que efetivamente se tome consciência que a formação de psicanalistas, de uma certa maneira, exige esse trânsito e que o pensamento psicanalítico só pode existir, só pode viver, só pode se vitalizar, na medida em que a gente se entregue a essa dimensão transdisciplinar". (Figueiredo, 2001)

Do ponto de vista de Karl Pribram (1976) o Projeto seria uma obra neuropsicológica. O neurologista afirma que seu interesse pelo Projeto para uma psicologia científica (Freud, 1895) se deu devido à sua 'sofisticada neurofisiologia'realizada no contexto de idéias do final do séc XIX ${ }^{8}$. Pribram afirma porém que as observações clínicas de Freud nos anos posteriores permitiram desenvolver uma metapsicologia de forma completamente independente de qualquer modelo neurofisiológico.

\footnotetext{
8 "There is truly a tradition in neuropsychology, a tradition shared by Freud, which, over the past two centuries has developed a fairly valid but testable and modifiable picture of the mind/brain relationship. Much of this picture was developed in the nineteenth century and has been passed on to us in Freud's 1895 Project for a Scientific Psychology" (Pribam, Annals, pg 19).
} 
Com uma leitura contraposta a esta, autores como Mezan (2001) afirmam que o Projeto surgiu num contexto de estudo da psicopatologia da histeria, especificamente para responder à pergunta: "Por que os histéricos sofrem de reminiscências? A memória é uma função psíquica normal; trata-se de descobrir em que ela consiste e através de que processos ela se transforma" (Mezan, 2001, p. 31).

Intercâmbios da psicanálise com as neurociências, como a proposta pela neuropsicanálise, têm causado interesse em alguns psicanalistas pela curiosidade quanto ao padrão geral de funcionamento do cérebro, ou seja, o problema mente-corpo. André Green ao comentar de forma cuidadosa os trabalhos sobre a teoria dos afetos numa perspectiva neurocientífica (Green, 1999) diz que esta comunicação deve envolver mútua educação sobre as restrições de cada método, inclusive considerando a forma discrepante de pensar dos pesquisadores de cada um dos campos, em níveis de complexidade também diversos. Afirma que este conhecimento colocado em perspectiva pode ser uma aquisição importante, devido ao esforço enorme que não pode ser feito sem a ajuda do tempo. Aos interessados pela empreitada Green aconselha: "Freud não tem uma forma correta de ser considerado, como percebendo a verdade mais que seus seguidores, que podem discordar dele. Mas, em minha opinião, Freud tem consistência substancial mais forte que qualquer outro, mesmo que isto seja agora posto em questão. 0 que eu recomendo é estudar seu trabalho na tentativa de captar sua consistência interna mais que considerando os fatos isolados para os quais ele dispensou atenção. Isto para mim é rigor verdadeiro, ao invés de ir encontrando apressadamente compromissos impossíveis entre métodos incompatíveis" (Green, 1999, p.44). Coloca em xeque a possível proposta de acrescentar elementos à teoria Freudiana, pois que se constitui numa obra completa.

Um artigo muito interessante sobre os fundamentos biológicos do processo analítico relaciona este processo com a aprendizagem implícita inconsciente (Slipp, 2000). Segundo 
o autor, com o desenvolvimento da técnica freudiana que inclui o uso do divã e a tolerância, o paciente deixou de assistir às expressões faciais do analista estabelecendo uma forma de comunicação subliminar e de estados emocionais, minimizando a ativação de estruturas relacionadas com medo, como a amígdala. Com a sensação de segurança propiciada pelo analista, o paciente pode experimentar novamente memórias antigas de forma não ameaçadora, diminuindo a atividade da amígdala. Biologicamente, novos caminhos neurais do córtex até a amígdala podem se estabelecer, pois o córtex tem possibilidade de rearranjo funcional, denominado plasticidade. De fato, estudos sobre plasticidade neural em animais têm levado os neurobiólogos do desenvolvimento à conclusão de que a diferenciação cortical e a especialização funcional são em grande medida produtos de inputs do córtex.

O discurso funcional da neuropsicologia tem pouca semelhança com elementos da teoria psicanalítica. Peço, portanto, desculpas pelas bruscas alterações epistemológicas presentes no texto, e acredito que seja necessário desenvolver uma nova postura de investigação neurobiológica, que parta da vivência subjetiva. 0 diálogo realizado neste trabalho entre neurociências e psicanálise se baseia na premissa de que foi considerado importante encontrar os fundamentos neurobiológicos de processos psíquicos, em relação, por exemplo, aos períodos críticos para o desenvolvimento de áreas sensoriais do córtex cerebral (Shore, 1994). Em sentido inverso, a psicanálise, como campo de tratamento e investigação da subjetividade, pode contribuir de forma consistente para um conceito mais rico de homem.

Freud esclarece que o pensar consciente rotineiro e o pensar científico se assemelham na forma de lidar com a realidade, considerada fora e independente de nós: “o pensar científico não difere, em sua natureza, da atividade normal do pensamento que todos nós, crentes ou incrédulos, empregamos ao cuidar de nossos assuntos na vida 
corrente. Ele apenas desenvolveu determinados aspectos: interessa-se por determinadas coisas, conquanto estas não tenham uso imediato, tangível; procura evitar, cuidadosamente, fatores individuais e influências afetivas; examina mais rigorosamente a credibilidade dos sensos de percepção nos quais baseia suas conclusões; equipa-se com novas percepções que não se podem obter pelos meios habituais, e isola os fatores determinantes dessas novas experiências em experimentações modificadas deliberadamente. Seu esforço é no sentido de chegar à correspondência com a realidade ou seja, com aquilo que existe fora de nós e independentemente de nós, e, segundo nos ensinou a experiência, é decisivo para a satisfação ou a decepção de nossos desejos. A essa correspondência com o mundo externo real chamamos de 'verdade'. Permanece este o objetivo do trabalho científico, ainda que deixemos de considerar o valor prático desse trabalho" (Freud, ). A consciência em si não é receptáculo de lembranças; Freud caracteriza o processo consciente como evanescente, pois os processos excitatórios exaurem-se no fenômeno de tornarem-se conscientes, afirmando que "a consciência surge em vez de um traço de memória" (Freud, muito além do princípio de prazer,1920).

Retornando às neurociências, achados de estudos de neuroimagem não geram expectativa de encontrar localidades das funções psíquicas no encéfalo. Cito Freud em A questão da análise leiga, como norteador da conexão entre estudos de neuroimagem e metapsicologia, ao responder o que é, afinal, o 'aparelho mental', ele diz: “Logo tornar-se-á claro o que é o aparelho mental; mas peço-lhe que não me pergunte de que material ele é construído. Isso não é assunto de interesse do psicológico. A psicologia pode ser tão indiferente a ele como, por exemplo, a óptica pode ser para se as paredes de um telescópio são feitas de metal ou papelão. Deixaremos inteiramente de lado a linha material de abordagem, mas não a espacial, pois imaginamos o aparelho desconhecido que serve às atividades da mente como sendo realmente um instrumento de várias partes (que 
denominamos instâncias), e cada uma das quais desempenha uma função particular e tem uma relação espacial fixa umas com as outras, ficando compreendido que por relação espacial - "em frente de" e "atrás", "superficial" e "profundo" - simplesmente queremos dizer em primeiro lugar uma representação regular das funções." Ele segue: “o valor de uma ficção (hipóteses científicas) desta espécie depende de quanto podemos alcançar com sua ajuda" (Freud, 1926, p.221-222).

Do nosso ponto de vista à medida que a primeira psicanálise freudiana com seus fundamentos deterministas, abriu mão de discutir questões próprias do ser ou metafísicas, desenvolvendo uma teoria baseada em força e mecanismos, sob influência do pensamento positivista da época, ela tem relação com o estudo do encéfalo e de suas funções. Apesar da obra de Freud ser tributária de diversas tradições há, claramente tradições científicas explícitadas pelo próprio Freud, como na afirmação: “Também, a psicanálise é uma ciência natural. O que mais poderia ser?" (Freud, 1940, p.317).

Com este foco de investigação surgiu a neuro-psicanálise, com o lançamento da revista Neuro-psychoanalysis - an interdisciplinary journal of psychoanalysis and the neurosciences. Na carta dos editores de seu primeiro número, anunciou-se a proposta de comunicar aos pesquisadores de ambas as áreas matérias de interesse comum, devido ao 'avanço extraordinário' da neurociência e descobertas de interesse vital aos psicanalistas, dados que não foram incorporados à psicanálise (Solms e Nersessiam, 1999). 0 corpo editorial está composto por pesquisadores de forte projeção acadêmica na neurociência como Eric Kandel, Joseph Le Doux, Benjamin Libet, Karl Pribram, Oliver Sacks, Allan Schore, dentre outros incluindo psicanalistas de forte projeção clínica/teóricacomo nova possibilidade da psicobiologia, e com a meta de conciliar perspectivas neurocientíficas e psicanalíticas sobre a mente, considerando que as duas disciplinas têm se engajado na tarefa de entender as complicações do funcionamento mental, mas a partir de perspectivas 
completamente diversas (Solms and Nersessian, 1999). A neurociência engloba áreas de conhecimento que investigam a dinâmica do cérebro e de suas conexões com as funções psíquicas, tanto em estado de normalidade como em estados patológicos.

A psicanálise serve aos psicanalistas enquanto técnica de acesso ao inconsciente para ajudar pessoas em sofrimento: “... pois não queremos ouvir do nosso paciente somente o que ele sabe e esconde dos outros; é preciso que ele nos diga também o que não sabe" (Freud in Sandler, 2003). A neuro-psicanálise se propõe a tratar de pacientes antes considerados 'neurológicos' pelo método psicanalítico, e sob o enfoque romântico neuropsicológico de 'estudos de caso', relaciona a neuroanatomia-funcional com fenômenos da clínica como a repressão, tipos de transferência, etc. Além disso se extende ao campo teórico por meio da criação de novos modelos nos quais elementos teóricos da psicanálise são relacionados com a neuroanatomia-funcional como a desenvolvida por Allan N. Shore $(1994 ; 1997 ; 2003)$ que, por meio da revisão monumental no campo da neurofisiologia, fundamentou a instauração complexa da habilidade para o bebê se relacionar com o outro com um período crítico característico, antes da instauração da linguagem. Cada vez mais tem surgido teorias 'relacionais' sobre o desenvolvimento do encéfalo, como a teoria sobre empatia na neurociência cognitiva, afetiva e social. Nesse sentido temos que repensar se a crítica subjetivista e relacional sobre a limitação do estudo de mecanismos neuroanátomo-funcionais podem ser elaboradas com a premissa das limitações técnicas ou epistemológicas. Considero que o posicionamento depende da retomada de questões metafísicas sobre o conceito de homem. 


\section{Capítulo III - Empatia}

\section{III.1. Empatia na psicanálise}

No texto "Psicologia de grupo e análise do ego" Freud (1921) realiza uma análise dos fenômenos sociais e do que foi denominado como "indução primitiva de emoção" e aceita, num primeiro momento, que a imitação estaria subordinada `a sugestão, ou sugestão mútua dos indivíduos, relacionada ao prestígio dos líderes. Porém, logo a seguir o conceito de sugestão é substituído por libido. 0 grupo, então, é mantido pelo laço libidinal, ou pelo amor deles. Nas antipatias e aversões indisfarçadas que as pessoas sentem com pessoas que tem que tratar, se identifica o amor a si mesmo, ou narcisismo. 0 amor de si mesmo só conhece uma barreira: o amor pelos outros. Quando um grupo se forma os membros se igualam entre si, e aquele ser aversivo deixa de sê-lo, ou seja, há um aumento da tolerância ao diferente. Só o amor atua como fator civilizador, no sentido de transformar egoísmo em altruísmo. 0 interesse de Freud é definir qual é a natureza dos laços do grupo que envolve gradações do estado de estar amando e ser amado. 0 mesmo laço relativo ao sentimento de estar amando, portanto, pode ser encontrado nos grupos, e este sentimento se relaciona com a identificação. A identificação é ambigua em si, pois se relaciona remotamente ao complexo de Édipo, no qual o menino toma o pai como seu ideal mas também como um rival no seu amor (catexia de objeto sexual) pela mãe. A identificação diz respeito aquele que gostaríamos de ser em e difere da escolha objetal de tipo sexual, ou `aquele que gostaríamos de ter: "Podemos apenas ver que a identificação esforça-se por moldar o próprio ego da pessoa segundo o aspecto daquele que foi tomado como modelo." (1921, p.134) Freud descreve a formação de sintomas neuróticos como um problema de identificação, ou decorrente do desejo de colocar-se na mesma situação de um outro. 
Aceitar o sofrimento do outro depende de um sentimento de culpa, e Freud considera errado supor que assumir o sintoma do outro se deva `a simpatia. Pelo contrário, a simpatia só surge da identificação. Freud, sobre "aceitar o sofrimento do outro" usa os termos “infecção" ou "imitação".

A imitação é compreendida por Freud (1912) dentro do contexto do animismo (atribuição de vida aos objetos inanimados), no qual as leis da natureza são substituídas por leis psicológicas por meio de uma enorme crença no poder dos desejos. 0 sistema de pensamento animista (ou mitológica) se distingue do sistema de pensamento religioso e do científico. Se relaciona com a satisfação alucinatória de desejo. Freud, sobre este tema ainda afirma que: "o fato de ter sido possível construir um sistema de magia contagiosa sobre associações de contiguidade mostra que a importância atribuída aos desejos e `a vontade foi extendida destes dois fatores a todos os atos psíquicos que estão sujeitos `a vontade." (Freud, 1912, p.107) No animismo, portanto, houve uma supervalorização dos processos mentais, uma "onipotência do pensamento" ou de si-mesmo, pela crença de que tudo o que for feito com a idéia da coisa acontecerá também `a coisa. "Se as crianças e os homens primitivos acham o brinquedo e a representação imitativa suficiente para eles, isto não constitui um sinal de que sejam despretenciosos (...) É o resultado, facilmente compreensível, da virtude suprema que atribuem aos seus desejos, da vontade que está associada a esses desejos e dos métodos pelos quais os desejos operam entendida como magia imitativa ou magia contagiosa." (Idem, p.106) Em Freud, a satisfação alucinatória de desejo, pode ser acompanhada de alucinações motoras. A telepatia vivida por um paciente obsessivo também tem um caráter puramente mágico, defesa mágica de desejos malignos e prova em favor do narcisismo. "A técnica do animismo, da magia, revela, da maneira mais clara e inequívoca, uma intenção de impor as leis que regem a vida mental `as coisas reais" (Idem, p.115) Neste referencial, as suposições da magia e a onipotência transportada aos 
espíritos prepara o caminho para uma religião. A separação entre mundo espiritual e aquilo que é fornecido pelos sentidos e pela consciência seria o reconhecimento da separação entre consciente e processos mentais inconscientes e seus processos projetivos. Freud declara que a superstição, a ansiedade, os sonhos telepáticos, os demônios, quando revelados pela psicanálise dependem de recalque e são obras do nível animista de pensamento.

Crianças se sentem facilmente aparentadas aos animais e deslocam a elas o medo das figuras dos pais, identificando-os com animais, como no totemismo, no qual há a identificação de um homem com seu totem. Em Freud o animal totêmico, em uma cultura anterior `a criação de deidades antropomórficas, é um substituto do pai.

Freud, sobre a identificação, conclui: "Já começamos a adivinhar que o laço mútuo existente entre os membros de um grupo é de natureza de uma identificação desse tipo, baseada numa importante qualidade emocional comum, e podemos suspeitar que essa qualidade comum reside na natureza do laço com o líder. Outra suspeita pode dizer-nos que estamos longe de haver exaurido o problema da identificação e que nos defrontamos com o processo que a psicologia chama de "empatia" (Einfühlung) o qual desempenha o maior papel em nosso entendimento do que é inerentemente estranho ao nosso ego nas outras pessoas." (Idem, p. 136)

Freud retoma a gênese do homossexualismo no qual ocorre a inversão no processo identificatório após o fim da puberdade. 0 menino, por logo tempo fixado na sua mãe repentinamente e por meio de uma renúncia `a sua identificação com o pai, passa a não abandona a mãe, mas passa a identificar-se com ela. Procura então objetos que possam substituir o seu ego para ele, aos quais possa dedicar o amor igual ao que recebeu de sua mãe. Esse aspecto remonta o caráter sexual do ego. 
Freud, portanto, relaciona Einfühlung com o processo de identificação, ou com o que gostaríamos de ser. A identificação descreve um laço emocional com o objeto. 0 mecanismo que relaciona empatia com a identificação seria a imitação, como o autor afirma: "Um caminho, por meio da imitação conduz da identificação `a empatia, isto é, `a compreensão do mecanismo pelo qual ficamos capacitados para assumir qualquer atitude em relação a outra vida mental." (Freud, 1921, p.139)

Este conceito de empatia, relacionado `a identificação, tem influência da teoria estabelecida por Lipps. Por outro lado, Freud considera a mímica, no seu trabalho "Sobre os dois princípios do acontecer psíquico" (1911), mero alívio de tensões de um aparelho psíquico sob domínio do princípio do prazer: "A remoção dos estímulos pela via motora, que sob o domínio do princípio de prazer se incumbia de aliviar o aparelho psíquico da sobrecarga de estímulos acumulados, e para este fim utilizava-se de inervações enviadas para o interior do corpo (mímica, exteriorização de emoções), recebeu agora uma nova função, passou a ser utilizada para modificar a realidade de modo eficaz.

\section{III.1.1. Conceito metapsicológico de Eu (Freud)}

A psicanálise se fundou na idéia de repressão, dando portanto ênfase, como dissemos, ao conflito intrapsíquico inerente à formação do Eu. Os aspectos intoleráveis da mente, ou pensamentos que não deveriam ocorrer são recalcados, expulsos da consciência e enviados para o inconsciente onde exercem vida própria. “Um pensamento, uma vez reprimido, não fica mais sujeito às normas que regem o pensamento racional consciente: é imune à contradição por outros pensamentos e aos efeitos corretivos de experiências subseqüentes. Um pensamento reprimido, no entanto, continua a exercer impacto sobre a mente; sua força decorre do fato precisamente de ter sido reprimido e, desse modo, afastado das influências moderadoras das idéias e percepções conscientes. A repressão 
danifica o ego ao retirar de seus domínios aquilo que, de outra maneira, seria uma idéia, deixando apenas o que Freud denominou 'representação de coisas' (Dingvorstellung), a qual afeta o ego, mas não pode ser avaliada (por este último pensada) à luz de outras idéias e experiências por que ela carece da capacidade de se ligar a outras idéias e experiências. (Freud julgava que isso ocorria em razão de a representação de coisas, não conseguir ligarse às palavras)." (Freud, 1915; in Caper, 2002, p.204).

O ego enquanto instância psíquica que dá conta do princípio de realidade (Porchat, 2005), ou de prazer adiado, em contraposição ao princípio prazer-desprazer, desenvolvese com diversas habilidades, como atenção, memória, capacidade de processar elementos perceptivos e sensoriais, efetuando, por meio do processo secundário, ligação entre elementos, ordenação segundo um princípio temporal compartilhado. Nesse sentido, em Freud, o ego é a instância principal da consciência, que apesar de ter suas bases no inconsciente, deve lidar com instâncias controladoras (superegóicas) e com o pulsional do id, fazendo valer o 'princípio de realidade', ou de 'prazer-adiado', em detrimento do princípio de prazer-desprazer de descarga imediata. Por meio do teste de realidade o ego confronta fantasia com a realidade, e se relaciona com o compartilhado socialmente, sendo moldado também por ele.

Para Klein, o ego, a partir do nascimento é capaz e mais que isso, é impulsionado pelos instintos e pela ansiedade a formar relações de objeto, na fantasia e na realidade. A formação da fantasia é uma função do ego, pressuposto com um grau de organização muito maior do que foi usualmente postulado por Freud. 0 uso do mecanismo de identificação projetiva normal permite que a intersubjetividade seja compreendida como o campo da formação da subjetividade. O conceito de comunicação inconsciente (Freud, 1915) e de contra-transferência (aquilo que o analista sente como reação `a transferência do paciente), podem ser entendidos como precursores do conceito de identificação projetiva (Klein, ). Na 
escola inglesa de psicanálise o conceito de 'identificação projetiva' apresenta a experiência intersubjetiva como um campo marcado pela sobreposição de experiências emocionais. Por outro lado, como nos alerta Grotstein, como podemos escapar do irônico ponto de vista ao qual nos remete a identificacão projetiva segundo o qual identificar que percebemos o outro entrando dentro dele pode resultar em substituir o outro pelo self ou o self pelo outro? Em casos patológicos a identificação projetiva massiça pode ser sentida na forma de controle da mente do analista. Grotstein propõe o conceito de identificação transubjetiva. Bollas propõe o termo identificação perceptiva.

\section{III.1.2. Sobre o conceito de objeto}

Textos que versam sobre o conceito de identificação projetiva se fundamentam no conceito de objeto, revisto e ampliado por Melanie Klein. Autores que investigam o conceito de objeto na obra de Freud (Merea, 1994 "Os conceitos de objeto na obra de Freud") demonstram que existe um registro muito variado do conceito. Segundo este autor, na primeira tópica freudiana na qual a tônica recai sobre as pulsões, o objeto se equipara ao conceito de representação. Já na segunda tópica freudiana se destaca o papel da identificação, e o objeto tem importância como estruturante da instância psíquica, portanto irredutível à mera representação. 0 conceito de objeto não é unívoco e perpassa conceitos como narcisismo (onde o ego torna-se objeto da pulsão), a fantasia inconsciente (objeto da percepção), objeto de identificação (objeto do luto) ganhando em termos de amplitude e se interpondo entre o sujeito que experimenta e a possível realidade independente deste. Essa forma de Freud abordar o conceito de objeto permite que o real permaneça sempre um exercício de apreensão do incognoscível. Dentre as dificuldades se compreende que Freud sustenta, ao mesmo tempo, que os investimentos de objeto partem do ID e não chegam ao ego senão secundária e indiretamente por intermédio da identificação (os objetos seriam o 
meio pelo o qual o ego recebe influxos do ID), e, outras vezes, que a libido vai do ID para o ego que seria, este sim, fonte na direção dos objetos. Klein simplifica este assunto afirmando que apenas o ego seria fonte de distribuição de libido, mesmo que seja de sua parte inconsciente.

Por outro lado, o narcisismo foi descrito inicialmente por Freud como um momento do desenvolvimento do indivíduo, no qual se unificam os instintos sexuais engajados em atividades auto-eróticas e este toma como objeto de amor ele mesmo, para depois passar a uma outra fase na qual busca obter o amor de um objeto que não é ele mesmo. Klein ampliou o pensamento freudiano partindo do princípio de que há relação de objeto desde o nascimento e que seriam contemporâneas, portanto, ao auto-erotismo e ao narcisismo. Segundo diversos autores, a revolução proposta pelo seu pensamento retirou a ênfase nos processos de identificação e na relação entre fantasia e realidade, transferindo para a constituição do mundo interno.

Porém, como bem pensou André Green, “consideremos um organismo que tem pulsões que se exprimem no somático: suas pulsões só chegarão a existir e só serão para ele objeto de conhecimento, ou só mobilizarão nele mecanismos de significação, na medida em que o objeto as revelar. 0 que quer dizer, de modo mais claro, que é através da existência do objeto e, em particular, da falta do objeto, que a pulsão se faz sentir, pois a pulsão satisfeita quase não faz sentir seus efeitos" (Green, 1990, p.71). Objetos primários pulsionalizados servem de base para todos os processos de ligação e permitem a vigência do princípio de prazer e de realidade. Por outro lado, a pulsão de morte seria o malogro da procura pelo objeto da pulsão, com decorrentes tendências à descarga e desobjetalização (Green, 1990). O objeto "absolutamente necessário" quando preenche sua função constitutiva estimulante e continente, é negado. Negado 'para fora' converte-se em objetos de atração e repulsão e 'para dentro' converte-se em estrutura psíquica enquadrante, ou 
vazio. 0 vazio funcionaria como base desejante colocando a vida mental em movimento de busca, apreensão, realização, etc. "A pulsão não tem a capacidade em si de ligar ou desligar objetos, ela apenas pulsa" (Figueiredo, 2004). São os objetos primários pulsionalizados que servem de base para todos os processos de ligação ("o objeto é o revelador da pulsão").

\section{III.1.3. Self em Melanie Klein}

Ego, self e sujeito aparecem de forma indiscriminada na obra de Melanie Klein, e segundo Hilshelwood (1992), mais no final de sua produção Klein afirmou: "self é usado para abranger a totalidade da personalidade, que inclui não apenas o ego, mas também a vida pulsional que Freud chamou de 'id' (Klein, 1959, p.249, in Hilshelwood, 1992); já o ego é “(...) a parte organizada do self”.

Segundo diversos autores, a revolução proposta pelo pensamento de Melanie Klein retirou a ênfase nos processos de identificação e na relação entre fantasia e realidade, e colocou ênfase na constituição do mundo interno. Melanie Klein ampliou o pensamento freudiano com sua teoria das relações objetais, segundo o princípio de que há relação de objeto desde o início do nascimento, contemporâneas, portanto, ao auto-erotismo e ao narcisismo. 0 narcisismo foi descrito inicialmente por Freud como um momento do desenvolvimento do indivíduo, no qual se unificam os instintos sexuais engajados em atividades auto-eróticas e este toma como objeto de amor ele mesmo, para depois passar a uma outra fase na qual busca obter o amor de um objeto que não é ele mesmo. Também pôde incluir o papel da pulsão de morte desde o início da vida do bebê, enquanto 'agressividade', ou impulsos de ódio atribuídos ao objeto frustrador mau, e revertido em persecutoriedade. De fato, Melanie Klein, pela observação de bebês e suas primeiras relações objetais, encontrou uma solução metapsicológica para a passagem da primeira tópica freudiana para a segunda. Ou seja, a agressão ou a destrutividade eram consideradas 
inicialmente como resposta à frustração, ou inerente à natureza pré-genital (decorrente de impulsos parciais não fusionados) e na segunda tópica (Freud, 1924), Freud separou claramente dois princípios de funcionamento mental, na chamada 'pulsão de morte' versus a 'pulsão de vida'. Com isso, o narcisismo primário ficou sem lugar, posto que uma cota de pulsão de morte já participava dos processos primários constitutivos do ego. Melanie Klein propôs uma solução à esta questão com o desenvolvimento da teoria da relação de objeto, e suas duas posições básicas como veremos a seguir. Cintra e Figueiredo (2004) afirmam que as observações clínicas de Klein e sua teoria com ênfase no relacionar-se aos objetos de amor nos primórdios do desenvolvimento psíquico, tornaram visíveis alguns processos intangíveis. Especialmente nas etapas pré-genitais se estabelecem duas formas de relação de objeto, a chamada "relação de objeto parcial" e a "relação de objeto total".

\section{III.1.4. Posição esquizo-paranóide e posição depressiva}

Melanie Klein privilegiou o estudo dos estágios iniciais do desenvolvimento, com ênfase nas angústias, defesas e relações de objeto. Sua longa observação de bebês e crianças pequenas permitiu que desenvolvesse uma teoria sobre os processos constitutivos do self , partindo de um ego arcaico e suas defesas típicas até um ego estruturado sobre outros princípios, que considera o outro e teme pelo seu desaparecimento ou prejuízo.

Melanie Klein parte do conceito básico de que as primeiras experiências do bebê de alimentação e presença da mãe iniciam uma 'relação de objeto' com esta. A característica principal desta primeira relação é ser, como ela denominou, relação de objeto parcial, posto que neste primeiro momento (situado dos três aos quatro meses de vida, mas também por toda a vida, posto que é um mecanismo de funcionamento psíquico), há intensas projeções de impulsos orais, tanto libidinais quanto destrutivos, e portanto, o objeto não se constituiu enquanto 'todo' na mente, também incipiente, do bebê. Nesta posição, o seio à medida que 
é gratificador (alívio da fome, prazer de mamar, liberação do desconforto e tensão, experiência de ser amado) é, por sua vez, amado e sentido como bom. Por outro lado, na medida em que é fonte de frustração, é odiado e sentido como mau. Esta antítese entre seio bom e seio mau é fonte de grande desintegração do ego, sujeito a processos de cisão. Além das experiências de gratificação e frustração, caracterizadas pela autora como 'fatores externos', processos de projeção e introjeção, de característica endopsíquica, contribuem para um tipo de relação 'dupla' com o primeiro objeto. Ou seja, o bebê projeta seus impulsos de amor, (atribuindo-os ao seio gratificador bom) e projeta seus impulsos de ódio (atribuídos ao objeto frustrador mau). Simultaneamente, porém, um 'seio bom' e um 'seio mau' são estabelecidos dentro dele, devido ao processo introjetivo. A principal ansiedade (angústia) deste estado é de qualidade persecutória, posto que suas fantasias sádicas, qualidades destrutivo-orais dos impulsos do próprio bebê quando em estado de frustração e ódio (morder o seio, dilacerar, ataques com urinas venenosas e fezes explosivas, etc.) gera medo de retaliação, medo de perseguidores internos e externos, medo da voracidade do objeto (à medida da própria voracidade), ou seja, "o seio mau o devorará da mesma forma voraz que ele deseja devorá-lo" (Klein, 1952, p.88). A gratificação e o amor que o bebê vivencia possibilitam amenizar a ansiedade persecutória, sendo gratificadora a proximidade física durante alimentação, pois permite o aumento da confiança no 'objeto bom'.

Processos de idealização servem como método de defesa típico desta posição, e com a gratificação alucinatória, permite que o seio persecutório seja mantido sob controle bem longe do seio gratificador. Esse processo é chamado de cisão do objeto e dos sentimentos em relação à ele, e liga-se à negação, ou aniquilamento de qualquer objeto ou situação frustrante e ao sentimento de onipotência. Segundo a autora, o principal elemento que 
mantém a cisão interna do self é a inveja do objeto primário e o trabalho psicanalítico para que tenha algum sucesso deve permitir que isso seja trabalhado na transferência.

Melanie Klein foi imensamente feliz ao anunciar duas posições básicas de funcionamento mental. A 'mente incipiente', por meio de processos de projeção e introjeção, lida com angústias fundamentais, desde o primeiro trauma do nascimento, passando pela experiência do bebê com fome, dor, estranhamento, experiências afetivas que não podem ser combinadas de forma a constituir uma totalidade, sendo portanto vividas como elementos evacuados de uma mente incipiente, e, por outro lado, o mecanismo de funcionamento da 'posição depressiva'. A posição depressiva seria um momento no desenvolvimento psíquico, mas também apenas um modo de funcionamento, por meio da qual a mente lida com totalidades significativas de sentimentos, incluindo aspectos frustradores e gratificadores do objeto, e de si-mesmo, posto que um sentido de self se estabelece. Predomina o amor e o medo de prejudicar a si-mesmo e aos objetos amados, segundo o modo depressivo de funcionamento, e tem lugar uma narrativa do simesmo, que necessita de um núcleo interno adquiridos no tempo. Alguns autores (Cintra e Figueiredo, 2004) associam a primeira relação de objeto à 'lei da selva', enquanto que a segunda forma de relação objetal dependeria da instalação de uma 'lei da cultura e do social'. Pela 'lei da selva' o objeto de amor aparece como um objeto a ser consumido ou submetido, "quando não existe a capacidade de cuidar e preocupar-se com o destino do "outro", que, aliás, ainda não é sequer reconhecido em sua existência autônoma e separada" (Cintra e Figueiredo, 2004, p.62).

A repetição do ato de introjeção de objetos bons destina-se a testar a realidade de seus temores e refutá-los. Nesse estágio o ego é impelido mais do que nunca, por amor e necessidade, a introjetar o objeto bom. Aumento da introjeção também ocorre devido à fantasia de que o objeto amado pode ser conservado dentro do sujeito em segurança. 0 ego 
identificado com o objeto também não abandona seus primeiros mecanismos de defesa mas o temor de que o objeto bom seja expulso com o mau faz com que os mecanismos de expulsão e projeção percam seu valor. O ego está impelido pela sua identificação com o objeto bom a repará-lo por seus ataques sádicos, o dano que a criança em sua fantasia inflige aos pais. Todo ato de violência cometido por um objeto contra outro, primeiro por ódio, depois por auto-defesa, incluindo o coito destrutivo e sádico dos pais acontece tanto no mundo exterior quanto dentro do ego, já que o ego está absorvendo constantemente todo o mundo exterior. Nessa fase objetos bons e maus estão mais diferenciados e o ódio do sujeito se dirige aos segundos enquanto que o amor e a reparação aos primeiros. A angústia típica da posição depressiva é medo que os objetos bons e com eles o ego sejam destruídos, ou se encontrem em estado de desintegração. 0 ego se confronta com a realidade psíquica de que seus objetos de amor se encontram em estado de dissolução - aos pedaços - e o desespero, a culpa e a ansiedade que daí derivam formam as situações: a) como juntar os pedaços de maneira correta no seu devido tempo; b) como recolher os pedaços bons e desfazer-se dos maus; c) como fazer reviver o objeto depois que se juntaram os pedaços; d) ansiedade de ser interrompido nesta tarefa por objetos maus, pelo ódio, etc.

\section{III.1.5. Identificação Projetiva}

O conceito de identificação projetiva foi introduzido por Klein em 1946 no artigo “Notas sobre alguns mecanismos esquizóides". Neste artigo o foco da autora foi descrever a posição esquizo-paranóide, e a identificação projetiva foi descrita apenas como uma, dentre outras defesas contra ansiedade paranóide primitiva. Ela diz:

“Junto com os excrementos nocivos, expelidos com ódio, partes excindidas do ego são também projetadas na mãe, ou, como prefiro dizer, para dentro da mãe. Esses 
excrementos, essas partes más do self são usados não apenas para danificar, mas também para controlar e tomar posse do objeto. Na medida em que a mãe passa a conter as partes más do self , ela não é sentida como um indivíduo separado, e sim como sendo o self mau. Muito do ódio contra partes do self é agora dirigido contra a mãe. Isso leva a uma forma particular de identificação que estabelece o protótipo de uma relação de objeto agressiva. Sugiro o termo "identificação projetiva" para esses processos." (Klein 1946; p.27)

O segundo uso do conceito de identificação projetiva apresentado por Melanie Klein se deu em 1955 (Sobre a identificação, in Klein, 1991). Neste texto ela afirma que a identificação projetiva não era apenas um mecanismo mental, mas que fundamentalmente constituía uma fantasia inconsciente sobre relações de objeto internas e externas. Klein afirma que o mecanismo projetivo subjacente à empatia é bem conhecido. Por outro lado, identificação por projeção implica uma combinação de excisão de partes do self e da projeção destas para dentro de outras pessoas. Segundo James Grotstein (2006), nesse momento Melanie Klein diferencia o que seria a projeção segundo a noção freudiana clássica de mecanismo de defesa para fantasia inconsciente e relação de objeto (mecanismos internos e externos, respectivamente). Ainda segundo este autor, esta alteração foi fundamental para transformar o conceito de projeção para a identificação projetiva.

Segundo Klein, a cisão normal e a identificação projetiva seriam processos necessários do desenvolvimento, sem os quais a diferença básica entre eu-outro e entre bom e mau não seriam estabelecidas. Na posição depressiva o self e o outro são distinguidos com clareza, o indivíduo reconhece que a pessoa amada e a odiada são a mesma pessoa, e pode aceitar a responsabilidade por seus ataques.

Spillius, por exemplo cita: "Ela (Klein) não considerava que o paciente literalmente colocasse coisas para dentro da mente ou do corpo do analista. Era também sua opinião 
que, se o analista era influenciado pelo que o paciente fazia a ele, isto era evidência de alguma coisa que o analista não estava conseguindo enfrentar, o que significava que ele próprio precisava de mais análise (...) Ainda é de modo geral aceito, ao menos por analistas kleinianos ingleses, que a identificação projetiva é uma fantasia, não um ato concreto, mas se aceita agora que os pacientes comportam-se de modos tais que o analista acaba experimentando os sentimentos que o paciente, por uma ou outra razão, não pode conter dentro de si ou não pode expressar de outro modo, exceto levando o analista a ter também a experiência". A transferência, descrita pelos autores da escola neo-kleiniana inglesa, pode ser definida como: “tipo de confusão causado pela identificação projetiva em que a mente do paciente confunde seus próprios atributos com os do analista" (Carper, 2002, p.205) que possibilita que se resolva a neurose prévia. Isto se daria dado que a neurose de transferência que emerge de forma espontânea durante a análise substitui a neurose prévia e, portanto, a resolução da neurose de transferência através da análise resolve a neurose prévia. Porém, patologias que trazem em si questões sobre o "aquém da representação", como as patologias psicossomáticas, ou as estruturas que manifestam menos consistência subjetiva, como borderlines, adesivas e autistas colocam dificuldade técnicas muito além da transferência. Um autor importante, que lidou especialmente com pacientes borderline e psicóticos, foi Rosenfeld (1987), que enfatizou a importância de discriminar os motivos do uso deste mecanismo por estes pacientes, que inclui: comunicação, empatia, evitação da separação, evacuação de sentimentos desagradáveis ou perigosos e o tomar posse da mente do outro. Este último uso da identificação projetiva foi também designado como 'identificação aquisitiva' (Britton, 1989) e de 'introjeção extrativa' por Christopher Bollas (1987).

III.1.5.1 Desenvolvimento do conceito de identificação projetiva 
Diversos autores pós-kleinianos estudaram a identificação projetiva. 0 desenvolvimento do conceito se deu em diversas direções, mas foi de fundamental importância as reformulações propostas por Wilfred Bion. Na década de 50, Bion diferenciou entre identificação projetiva normal e patológica, relacionando-os, na clínica, com dois conceitos fundamentais, mais especificamente a relação entre continente-contido. De fato, diversos autores concordam que com este autor o conceito de identificação projetiva tomou proporções novas. A visão kleiniana de projeção e identificação projetiva foi substituída por uma versão intersubjetiva.

Wilfred Bion, no artigo "Diferenciação entre a parte psicótica e não psicótica da personalidade" (1957) caracteriza duas formas de identificação projetiva, a normal e a patológica. A identificação projetiva dentro de um desenvolvimento normal permite que na posição depressiva sejam reintegrados aspectos excindidos não excessivamente fragmentados. Por outro lado, na identificação projetiva patológica há um intenso ódio à realidade e o ataque se dirige também às partes perceptivas do ego, que são projetadas com violência para dentro do objeto. 0 destino desta projeção se dá em um contexto que foi denominado por Bion como 'contido' e 'continente'. A ação do continente no desenvolvimento normal implica em transformar as partes projetadas em experiência assimilável, ou seja, em elementos mnêmicos e de pensamento. A ação continente, para Bion seria a possibilidade de receber os conteúdos intoleráveis da mente do outro e transformá-los, tornando 'elementos beta' em 'elementos alfa'. 0 continente e o conteúdo se relacionam de forma que a projeção de sentimentos maus ocorre na medida da capacidade do continente. Com a experiência qualificada como 'seio bom' os 'elementos beta' perdem suas qualidades tóxicas, destrutivas, e se tornam toleráveis, pois são reintrojetados e admitidos na mente do sujeito da identificação projetiva. 
Emoções que não encontram possibilidade de elaboração por meio de uma identificação projetiva normal, segundo Bion os 'elementos beta', como sensações de dor, ansiedades primitivas de desintegração, que por sua característica não são integráveis portanto circulam na mente em busca de uma ancoragem. Sabemos que esta ancoragem só pode ser encontrada no outro, devido à falta de aparelho que dê conta de tais aspectos intoleráveis e dolorosos. 0 outro, portanto, funciona como uma extensão da mente do sujeito, as fronteiras sendo inexistentes. Elementos dispersos, sem terem sido processados por um núcleo central de não se tornam experiência, ou seja, não entram no campo do sentido. Por outro lado 'elementos alfa', sendo símbolos com diversos significados, sujeitos à generalização, abstração e diferenciação são sujeitos ao sentido e ao teste de realidade.

A relação se dá em um campo genuíno de experiência marcada pela sobreposição de experiências emocionais, portanto deixando-se invadir pela subjetividade alheia e própria, que se constitui no confronto. Por meio do mecanismo de identificação projetiva normal Bion permite que a intersubjetividade seja compreendida como o campo da formação da subjetividade. Bion se utiliza seu "potente instrumento de observação do desenvolvimento emocional" denominado de de "visão binocular" para descrever o processo de integração psicossomática a partir de uma desintegracão somato-psicótica. Afirma que, consciente de que a visão que se deixa seduzir pelo óbvio, o analista deve ter sua atenção desviada deste território para que, desassistido da memória e do desejo, apreenda os "pensamentos selvagens" do outro, "situados sempre num espectro infra ou ultra sensorial". A teoria da consciência como órgão sensorial da qualidade psíquica na qual proliferam elementos que geram a separacão entre qualidades conscientes e inconscientes, por meio de uma permeável "barreira de contato”. Portanto, duas funções cruciais do aparelho psíquico são a correlação (entre as duas qualidades) e a auto-observação prejudicada. Ou seja, "o registro imparcial da qualidade psíquica do self fica comprometido, (já que) a visão de uma parte 
pela outra é, por assim dizer, "monocular". Bion afirma a absoluta necessidade de levarmos o paciente a utilizar sua visão binocular para integrar suas vivências pré e pós-natais, seu endoesqueleto com seu exoesqueleto, suas percepções infra-sensoriais com suas percepções ultra-sensoriais, em suma seu Soma e sua Psique".

Alguns autores definem a metapsicologia como operações econômicas que o psiquismo utiliza visando representar emoções através de "artimanhas estéticas" (Junqueira F., 2008).

A investigação que Bion propõe busca compreender o material clínico por invariantes que constituam funções psíquicas. 0 principal mecanismo de defesa da psicose para evitar o contato das partes boas e más cindidas, é a chamada "identificação projetiva". Bion a define como "a excisão que o paciente faz de uma parte de sua personalidade e a projeção desta para dentro do objeto, onde se instala às vezes como perseguidor, deixando a psique da qual foi excisada correspondentemente empobrecida". A identificação projetiva excessiva que ocorre na posição esquizoparanóide não permite que haja a introjeção suave de objetos bons gradualmente percebidos e as partes dos objetos cindidos e evacuados se aglomeram e se comprimem tornando-se objetos persecutórios, que desejam se vingar pelo que foi feito a eles, e passam a controlar parte da personalidade do paciente. Mantém-se um estado confusional, pelo excesso de identificação projetiva que substitui os mecanismos de repressão, introjeção e projeção, tornando-se impossível separar o "dentro" do "fora", pela impossibilidade de separar conteúdo consciente do inconsciente. 0 paciente psicótico se move num mundo onírico, universo de objetos que servem como conteúdos dos sonhos de não psicóticos, com qualidades provindas de fontes diversas (características da matéria, objetos anais, sentidos, idéias, superego e demais características da personalidade). As qualidades e fontes destes objetos permanecem não diferenciadas. 
Segundo Bion, a dificuldade de se relacionar com objetos totais, típicos da posição depressiva, prejudicaria a utilização de símbolos e o desenvolvimento do pensamento verbal. A linguagem de pacientes psicóticos extremamente empobrecida e altamente compactada se deve pela predominância da posição esquizoparanóide, em detrimento da posição depressiva. Na posição depressiva estão ativos mecanismos de síntese e integração das experiências percebidas, mecanismos que pressupõem alto grau de abstração e simbolização, e o pensamento verbal tem o papel de sintetizar e articular impressões pela predominância da relação com objetos totais e dos mecanismos de simbolização e encadeamento de idéias.

$\mathrm{Na}$ análise dos pacientes psicóticos, o desenvolvimento do pensamento está sempre à mercê da destrutividade e aos perseguidores internos devido à intolerância à posição depressiva e ao pensamento verbal. A melhor forma encontrada para destruir qualquer forma embrionária de pensamento sobre a realidade é o chamado "ataque aos elos de ligação". A forma pela qual um elemento inconsciente torna-se consciente (Bion aqui retoma Freud) depende da instância pré-consciente: ao ligar-se às imagens verbais que lhe correspondem, algo se torna pré-consciente - lugar sem lugar onde o que Bion denominou como 'função alfa' pode exercer seu papel integrador.

A investigação que Bion propõe busca compreender o material clínico por invariantes que constituam funções psíquicas. 0 principal mecanismo de defesa da psicose para evitar o contato das partes boas e más cindidas, é a chamada "identificação projetiva". Bion a define como "a excisão que o paciente faz de uma parte de sua personalidade e a projeção desta para dentro do objeto, onde se instala às vezes como perseguidor, deixando a psique da qual foi excisada correspondentemente empobrecida". A identificação projetiva excessiva que ocorre na posição esquizoparanóide não permite que haja a introjeção suave de objetos bons gradualmente percebidos e as partes dos objetos cindidos e evacuados se 
aglomeram e se comprimem tornando-se objetos persecutórios, que desejam se vingar pelo que foi feito a eles, e passam a controlar parte da personalidade do paciente. Mantém-se um estado confusional, pelo excesso de identificação projetiva que substitui os mecanismos de repressão, introjeção e projeção, tornando-se impossível separar o "dentro" do "fora", pela impossibilidade de separar conteúdo consciente do inconsciente. 0 paciente psicótico se move num mundo onírico, universo de objetos que servem como conteúdos dos sonhos de não psicóticos, com qualidades provindas de fontes diversas (características da matéria, objetos anais, sentidos, idéias, superego e demais características da personalidade). As qualidades e fontes destes objetos permanecem não diferenciadas.

Segundo Bion, a dificuldade de se relacionar com objetos totais, típicos da posição depressiva, prejudicaria a utilização de símbolos e o desenvolvimento do pensamento verbal. A linguagem de pacientes psicóticos extremamente empobrecida e altamente compactada se deve pela predominância da posição esquizoparanóide, em detrimento da posição depressiva. Na posição depressiva estão ativos mecanismos de síntese e integração das experiências percebidas, mecanismos que pressupõem alto grau de abstração e simbolização, e o pensamento verbal tem o papel de sintetizar e articular impressões pela predominância da relação com objetos totais e dos mecanismos de simbolização e encadeamento de idéias.

$\mathrm{Na}$ análise dos pacientes psicóticos, o desenvolvimento do pensamento está sempre à mercê da destrutividade e aos perseguidores internos devido à intolerância à posição depressiva e ao pensamento verbal. A melhor forma encontrada para destruir qualquer forma embrionária de pensamento sobre a realidade é o chamado "ataque aos elos de ligação". Este funcionamento psicótico está presente na dinâmica do paciente borderline. A destrutividade dos pacientes psicóticos e pacientes bordeline se dirige aos "elos de ligação". A forma pela qual um elemento inconsciente torna-se consciente (Bion aqui 
retoma Freud) depende da instância pré-consciente: ao ligar-se às imagens verbais que lhe correspondem, algo se torna pré-consciente - lugar sem lugar onde o que Bion denominou como 'função alfa' pode exercer seu papel integrador.

Designa como elementos $\beta$ os fragmentos dos primeiros objetos estilhaçados, fragmentos de perceptos (como imagens ou falas). Os elementos $\beta$ circulam na mente sendo apenas evacuados. Os elementos $\beta$ não são transformados devido a um ataque à função $\alpha$ ou ataque à função que possibilita ligações entre diversos elementos. Os estímulos sensoriais permanecem na sua forma bruta sem tornarem-se elementos alfa e não são passíveis de serem registrados na memória e não se tornam elementos de pensamento. 0 trabalho do analista seria possibilitar que os conteúdos explosivos e tóxicos evacuados da mente do paciente se alojem na mente do analista para ali serem devaneados, elaborados, desintoxicados, ou seja, destituídos de sua eficácia traumatogênica, para serem devolvidos ao paciente na forma de interpretações. Podemos pensar que a clínica psicanalítica, portanto, não tem relação nenhuma com as verdades empiricamente testadas pelo método científico. Para Bion, apenas a mentira necessita de um pensador para criá-la. 0 analista quando faz uma interpretação, dá forma verbal à experiência que antes era não-verbal e inconsciente. 0 mais importante que o analista deixa (resultado das interpretações) não são, portanto, as identificações do paciente para com ele como pessoa, mas traços de uma experiência.

III.1.6. Donald W. Winnicott: mãe 'empática' propicia verdadeiro self

A prática clínica Donald W. Winnicott deu ênfase ao aspecto positivo da saúde, que inclui a capacidade de brincar (protótipo do viver criativo), possibilidade de entregar-se ao que ele veio caracterizar como 'espaço potencial', e de transitar por diversos mundos criados no decorrer do desenvolvimento - esta capacidade implica em estabelecer relações 
com o mundo objetivo sem muito sacrifício da espontaneidade pessoal (Dias, 2003). Dentro deste contexto, situa-se o conceito de self , como pensado por ele.

O self é considerado por Winnicott o núcleo da personalidade, unidade que está fisicamente contida na pele do corpo e psicologicamente integrada. 0 ego seria parte da personalidade que tende, sob condições favoráveis (dá grande ênfase ao ambiente), a se integrar em uma unidade (Winnicott, 1960). Segundo Winnicott, os bebês, no nascimento, estão de posse de um potencial de personalidade que apenas em parte é de responsabilidade genética. Esse potencial ou o self verdadeiro, no decorrer da vida, procura se expressar e se elaborar por meio do relacionar-se.

Outros autores dessa vertente psicanalítica, como Christopher Bollas (1987), situa o conceito de self verdadeiro no arcabouço metapsicológico enquanto compatível com o conceito de 'inconsciente reprimido primário', pela presença de instintos e formações mentais herdadas. Segundo este autor, o verdadeiro self seria o 'idioma da personalidade' e a essência da vida inconsciente, seria uma forma dinâmica que 'procura o seu existir através da experiência' (Bollas, ano, p.24).

Winnicott desenvolve de outra forma o conceito de 'posição depressiva', considerando-a a mais valiosa contribuição kleiniana para a psicanálise. Segundo ele, haveria uma fusão de impulsos eróticos e agressivos dirigidos a um mesmo objeto. 0 aspecto erótico propiciaria a busca da satisfação enquanto procura de objeto, enquanto que a agressividade empregaria um erotismo muscular e de ódio, mantendo porém um objeto bom em imagem para comparação. Nesse momento ambivalente o lactente estaria começando a relacionar-se com elementos que são cada vez menos fenômenos objetivos e cada vez mais percebidos como elementos 'não-eu'. Esta fase, constitui o self como "unidade que está fisicamente contida na pele do corpo e psicologicamente integrada" e, 
como afirma Winnicott: “daí em diante o lactente vive uma vida psicossomática”. (1960, p.72)

Neste momento a mãe torna-se, para a criança, uma imagem coerente, e, segundo o autor, o termo 'objeto total' pode então ser usado. 0 desenvolvimento depende de um ego se torne separado do ego materno e de uma realidade psíquica interna real. Com essa separação a criança pode sentir a riqueza pessoal que existe dentro do self .

O self verdadeiro vai se fortalecer a partir da experiência de continuidade da mãe (separada em mãe-ambiente e mãe-objeto) apesar dos ataques provindos do Isso (Id). Com a disponibilidade inabalável da mãe-ambiente e sendo empática com o lactente, ela naturalmente recebe o 'gesto espontâneo' e se alegra com isso. Com base na confiança, o bebê pode experimentar seus impulsos instintivos, a culpa não é sentida, ou permanece potencial caso não haja oportunidade de reparação. Todo esse processo, que como vimos foi descrito de outra forma por M. Klein, leva ao que o autor denominou de 'preocupação'. 0 lactente está mais apto a sentir-se preocupado, ou seja, a assumir responsabilidade por seus atos, e um sentido de tempo pessoal se instaura. Sobre o malogro deste processo, Winnicott afirma: "o fracasso da mãe-objeto em sobreviver ou da mãe-ambiente em prover oportunidades consistentes para reparação leva a uma perda da capacidade de se preocupar e à sua substituição por ansiedades e defesas cruas tais como splitting e desintegração". (Winnicott, 1962, p.74) Em processos desenvolvidos com sucesso, o lactente tende a se estabelecer como uma unidade, encarando o mundo com a sensação do "eu sou", vivendo seu corpo e construindo o self na base do funcionamento corporal e em elaborações imaginativas (conceito importante).

Segundo Winnicott, após o 'eu sou', segue-se o 'eu estou só'. Com a percepção (não necessariamente com a mente consciente) de continuidade da mãe, ou da existência contínua de uma mãe disponível, torna-se possível para a criança estar só e ter prazer 
nisso. Ou seja, o paradoxo é que a capacidade para estar só depende da experiência de estar só na presença de alguém. Ao situar a importância de se ficar só, o autor ressalta que a criança pode, então, descobrir sua vida pessoal própria. Essa descoberta só é possível com a presença de alguém disponível, presente, sem que haja exigências. Essa continência materna gera o impulso do id, e, nesse sentido, o 'estar só' para a criança bem sucedida se relaciona com o estado de relaxamento no adulto.

Apesar de Winnicott afirmar que apenas existe id se existir ego, ou seja que não se pode entender processos pulsionais sem a existência do ego, Bollas entende que Winnicott relacionou self verdadeiro ao id e o falso self ao ego. Este autor chamou de verdadeiro self o 'idioma da personalidade', que seria a origem do ego, e, portanto o ego desde início deve ter a habilidade em si de processar a 'vida'. Ele afirma: “o uso do self verdadeiro de um analista, é a força do idioma descobrindo-se por meio das experiências de objeto" (pg 28).

Segundo o autor, Winnicott ampliou o fator hereditário (predisposições para encontrar o seio, a face, o pai) descrito por Klein, ao descrever o 'gesto espontâneo' como potencial herdado de cada um. 0 uso que se faz dos pais seria no sentido de buscar o próprio idioma, e nos primeiros anos de vida da criança, uma mãe suficientemente boa facilita o 'natural', ou seja, o fortalecimento do self verdadeiro do bebê, e, dessa forma a criança sente a busca do objeto como útil. Ainda segundo Bollas, com o conceito de self verdadeiro, Winnicott deu nome a um aspecto da vida psíquica que não tinha sido ainda teorizado. Este conceito foi introduzido especialmente para designar um potencial herdado que encontrava expressão no 'gesto espontâneo'.

Segundo Winnicott, impulsos do id só são significativos se contidos na vivência do ego; a relação com o id fortalece um ego forte, e perturba um ego fraco. Esse relacionamento com o ego também foi denominado de relacionamento com a mãe, pois o ego só pode desenvolver-se em um meio protetor, que seria a mãe preocupada com sua 
criança e orientada para as necessidades do ego infantil, através da identificação com a sua própria criança. No Brasil, dentre os psicanalistas winnicotianos Safra (2000) diferencia claramente : "o eu seria para mim um campo representacional que permite ao indivíduo uma identidade nas dimensões do espaço e do tempo. Nem o self , nem o eu confundem-se com o ego, que é uma das instâncias intrapsíquicas de caráter funcional, articulador das demandas do id, do superego e da realidade." Segundo este autor: "tenho observado que cada pessoa constitui o seu self e a sua maneira de ser, por meio de determinada forma sensorial que ganhou predominância no mundo do bebê que ele foi. Para alguns a visão e o sentido fundamental, para outros, o tato, ou o uso da musculatura, a sonoridade, o ritmo e assim por diante." Estas experiências sensoriais, segundo o autor, constituem o principal eixo ordenador do self .

Segundo Bollas, caso os pais possuam um bom sentido intuitivo do seu bebê, que inclui a percepção de suas necessidades, a apresentação de objetos para "uso" e diversos tipos de representação do bebê, incluindo a face, a gesticulação corporal e a linguagem, ou seja, caso eles sejam sensíveis ao seu 'idioma de personalidade', ele, então, terá para si um mundo objetal facilitador. "Quando isso acontece, temos crianças que têm prazer em se representar celebrando as artes da transformação, porque vivenciaram a maternagem e a paternagem transformativas e sabem, pela autoridade concedida pela experiência interior, que é possível dar-se vida ao conhecimento latente." (pg22) Segundo a definição de Winnicott, o self verdadeiro seria o potencial herdado em contínua experiência do ser, adquirindo, de sua própria maneira e ritmo, uma realidade psíquica e um esquema corporal pessoais. 0 gesto espontâneo é manifestação do self verdadeiro, já presente no erotismo muscular do feto.

Safra (2000) ressalta: “o que se observa é o aparecimento do self, nos diferentes sentidos de realidade, em formas orgânicas. Nelas, as vivências de um indivíduo e seu estilo 
de ser constituem-se esteticamente. 0 self se constitui, se organiza, se apresenta por fenômenos estéticos." (Safra, 2000, p.25) Segundo Bollas, "se devemos estabelecer uma teoria para o self verdadeiro, acho importante enfatizar como o esse self -essência é a presença singular do ser que em cada um de nós é; o idioma de nossa personalidade". (Bollas, 1992) Segundo este psicanalista, o verdadeiro self se apresenta na medida em que o paciente se sente livre para usar o analista como um objeto "através do qual articula e elabora seu idioma da personalidade" (Bollas, 1992, p.20).

Por outro lado, em contraposição ao conceito de verdadeiro self, Winnicott apresentou 'um rótulo classificatório valioso' (1983, pg122) denominado 'falso self ', presente principalmente em quadro psicopatológicos, em graus variáveis de atuação. 0 falso self se constrói na base da submissão, pode ou não ter função defensiva de proteção ao verdadeiro self , e não permite que o sujeito sinta-se real, pois quando tem importância patológica (usado e tratado como real) provoca um sentimento de falsidade, futilidade e desespero. Muitas vezes acompanha uma dissociação entre mente e psicossoma, dissociação especialmente presente em quadros de extrema intelectualização. Para ele prevalecem as conquistas egóicas sobre as funções sexuais, e nesse sentido a vida instintual depende do desenvolvimento do ego para sua existência. A natureza humana, apesar de ter seu aspecto biológico, se diferencia radicalmente da experiência de outros animais especialmente pelo fato de que todas as funções corpóreas, incluindo os instintos, "passam pela via estritamente humana da elaboração imaginativa" (Dias, 2003; pg81). Segundo ele, não se pode avaliar a saúde em termos da vida pulsional e as defesas organizadas em relação à ela, não há id antes do ego. Os aspectos básicos da personalidade não seriam de caráter instintual, assim como se observa nas personalidades falso self . 
Um dos aspectos do pensamento de Winnicott é o pressuposto de que os processos de maturação sustentam os processos de desenvolvimento da criança, tanto quanto aos aspectos neurofisiológicos quanto psíquicos (Winnicott, 1963).

Christopher Bollas (2003) vai trabalhar mais intensamente na vertente deste objeto primário do paciente, devido ao pressuposto de que há um objeto primário não figurativo, ou seja, calcado menos no seu caráter especular do que no tumulto emocional que ocorre no self quando se o tem em mente. 0 sentimento de turbulência, portanto, seria o próprio objeto primário que determina um desejo borderline pautado na busca de um estado de tumulto. Cristopher Bollas (2006) propôs o conceito de identificação perceptiva. Segundo seu ponto de vista, um conceito singular como a identificação projetiva gera o risco de destruir a integridade do objeto-ele-mesmo. Seria difícil escapar do irônico ponto de vista segundo qual identificar que percebemos o outro entrando dentro dele pode resultar em substituir o outro pelo self . Um estágio de desenvolvimento após a posição depressiva foi proposta pelo autor, no momento que a criança pode perceber a integridade do objeto, denominado de 'era da integridade' de um objeto. Segundo Bollas, a teoria winnicotiana de 'uso do objeto' pressupõe o reconhecimento de um objeto integral pelo self . O conceito da identificação projetiva não é suficiente para explicar a percepção da identidade do objeto em si, mas apenas projeções do self dentro do objeto. A contraparte deste conceito, ou 'identificação perceptiva' se baseia na habilidade do self para perceber o objeto como uma coisa-em-si (thing-in-itself). Caso o self seja capaz disso ele pode aproveitar as qualidades do objeto e ser beneficiado pela sua integridade. A identificação perceptiva permite que amemos o objeto e constitui uma forma madura de amor que não funciona de acordo como os axiomas narcísicos de projeção e identificação. Por meio deste mecanismo e apesar da distância imposta pela diferença, o amor permitiria o desenvolvimento de uma profunda intimidade. A identificação perceptiva parte do pressuposto que self e objeto não são o 
mesmo, e que a diferença do objeto é vital ao self devido a sua 'separatividade' (separateness) e 'distintividade' (distinctness). Apesar de que, em termos do humano, a relação entre self e outro também compartilha elementos e estruturas psíquicas comuns.

Christopher Bollas (2003) vai trabalhar mais intensamente na vertente deste objeto primário do paciente, devido ao pressuposto de que há um objeto primário não figurativo, ou seja, calcado menos no seu caráter especular do que no tumulto emocional que ocorre no self quando se o tem em mente. 0 sentimento de turbulência, portanto, seria o próprio objeto primário que determina um desejo borderline pautado na busca de um estado de tumulto. Ferenczi, enfatiza que a permanência em um estado de fruição auto-erótica, parcial, leva necessariamente a um esgotamento do potencial de forças, pois `a medida que as pulsões não se ligam (como na pulsão genital), não se realiza uma ação efetiva em direção aos objetos da realidade externa. Considero que o objeto primário calcado no sentimento de turbulência mantém estes pacientes em um funcionamento mental primitivo, e calcado em um estado de gratificação alucinatória ao invés de um contato com a realidade que pressupõe um bom funcionamento do princípio de realidade. Uma forma de vida mental governada pelo princípio de prazer tende ao sofrimento, pois a realidade novamente retorna (pois a fome não foi de fato alimentada) e exige que a 'criança' entre em contato com uma fonte verdadeira de alimento, e se relacione de forma real com ela. $\mathrm{Ou}$ seja, considero que nestes pacientes uma colisão fatal com a realidade decorre da experiência calcada na satisfação alucinatória de desejo, que não encontra a via de satisfação na realidade, devido ao "não representado", constituição malograda do objeto primário.

III.1.7. O papel do negativo na constituição do self e a relação de objetos 
André Green considera a solução Kleiniana uma simplificação da metapsicologia, e propôs o conceito de 'narcisismo de morte', desenvolvido posteriormente como 'papel do negativo' na constituição do psiquismo. Segundo a teoria desenvolvida por ele, os objetos primários pulsionalizados servem de base para todos os processos de ligação e permitem a vigência do princípio de prazer e de realidade. A pulsão de morte, seria o malogro da procura pelo objeto da pulsão, com decorrentes tendências à descarga e desobjetalização (Green, 1990).

Segundo Andre Green, o objeto "absolutamente necessário" quando preenche sua função constitutiva estimulante e continente, é negado. Negado 'para fora' converte-se em objetos de atração e repulsão e 'para dentro' converte-se em estrutura psíquica enquadrante, ou vazio. Vazio funciona como base desejante e coloca a vida mental em eterno movimento de 'busca, apreensão, realização, etc.'. 0 que quer dizer, de modo mais claro, que é através da existência do objeto e, em particular, da falta do objeto, que a pulsão se faz sentir, pois a pulsão satisfeita quase não faz sentir seus efeitos" (Green, 1990, p.71).

Dessa forma, Figueiredo repete Green e Fairbairn que vêem na pulsão de morte uma espécie de malogro da procura pelo objeto da pulsão, com decorrentes tendências à descarga e desobjetalização (Figueiredo, 2003). No caso dos pacientes borderline o objeto absolutamente necessário nunca pôde ser bem encontrado, pois não cumpriu sua função, e permanece não podendo ser negado: "ele se torna excessivo e intrusivo, seja em suas funções estimulantes, seja, paradoxalmente, em suas funções de 'continência'” (Figueiredo, 2004, p. 20). Ao invés do objeto pulsionalizado que no tempo certo serviu para a constituição do psiquismo pela ação da negatividade, este objeto do paciente borderline entra em coalescência com a pulsão, potencializando-se mutuamente, permanecendo intrusivo. 
III.1.8. Psicologia do ego e self psychology

Desde o início de seu trabalho, Melanie Klein levantou as insuficiências da psicologia do ego, tendo apresentado as divergências publicamente em 1927 (Cintra e Figueiredo, 2003). Segundo a autora, as emoções do bebê muito pequeno têm forte intensidade, ou 'natureza poderosa e extrema', totalmente desconsiderados na vertente desenvolvida por Anna Freud. 0 termo self usado por Klein, por sua vez, foi caracterizado no fim de sua obra, como contendo elementos do id, enquanto que ego seria a instância psíquica mais relacionada com as leis do princípio de realidade.

Segundo Hartmann (primeira apresentação 1937, 1962) até então a teoria psicanalítica tinha se detido na noção de conflito em detrimento do que ele chamou de 'zonas livres de conflito', que junto com a noção de adaptação à realidade, permaneceram fora do interesse dos psicanalistas. A partir daí ele ampliou as premissas da psicologia do ego desenvolvida por Anna Freud, que já considerava como principal meta terapêutica da psicanálise e da educação propiciada por ela, a adaptação ou ajuste à realidade e socialização da criança. Segundo este autor, a psicologia do ego se diferencia de outras psicologias ditas 'suferficiais' e se detém em uma tarefa relegada pela psicanálise, que seria o estudo do processo de 'adaptação ao ambiente'. Hartmann parte do pressuposto de que, apesar do ego se desenvolver a partir do conflito, não é apenas esta a raiz de seu desenvolvimento. Segundo ele, nem toda adaptação ao ambiente e, portanto, nem todo o processo de aprendizagem e maturação implicam em conflito. Hartmann adota o termo ‘área sem conflito do ego' que delimitaria um conjunto de funções fora do campo dos conflitos mentais. 0 conflito mental e o desenvolvimento interno "pacífico" se coordenam mutuamente. 0 ego não seria o simples resultado de forças estranhas, mas sua função sintética constitui um órgão específico de equilíbrio à disposição da pessoa, e seu principal princípio regulador seria o princípio de prazer. 
O texto do autor não deixa claro como as possibilidades de prazer dos 'aparatos' da ‘área sem conflito do ego' exerce o papel de adaptação ao mundo externo. Segundo ele, destas 'fontes de prazer' o ego se desenvolve, mas também o autor defende que, para existir, o ego depende da maturação somática de 'certos aparatos', da mesma forma que o desenvolvimento das fases libidinais necessita da maturação somática. A adaptação à realidade, por sua vez, depende da maturação destes aparatos, e de 'ações intencionais controladas pelo ego', que se opõem aos possíveis transtornos de forma ativa e melhoram as relações da pessoa com o ambiente.

Outro ponto importante de discordância com a psicanálise clássica decorre da consideração de que a pulsão de morte, na forma de compulsão à repetição, tenha um fator positivo no desenvolvimento, pois também serviria como mecanismo de adaptação nas neuroses traumáticas. Segundo Hartmann, o equilíbrio intrapsíquico se manifesta também como transtorno de adaptação.

A adaptação, segundo o autor, depende do nível mental e da riqueza e amplitude da diferenciação do 'mundo interno', e o pensamento teria grande ênfase nesse processo adaptativo, dependendo, este também, de processos de diferenciação e síntese. A diferenciação pode se limitar devido às tendências regressivas, como 'sentimento de fusão com o objeto', ou um 'estado narcisista primário'. O desenvolvimento da 'função de diferenciação' encontra expressão psicológica não apenas na formação das instâncias mentais, mas também na apreciação da realidade, no juízo, na extensão do mundo de percepção e de ação, na separação da percepção e da imaginação, no conhecimento do afeto, etc. 0 equilíbrio destas funções pode gerar disfunções devido à precocidade da diferenciação, ou devido ao atraso em relação à síntese. Segundo o autor diferenciação e síntese são processos fundamentais do ego. 
O pensamento deste autor nos coloca frente a diversas contradições, como o reconhecimento do valor adaptativo dos conflitos, simultâneo às limitações que os conflitos impõem para o desenvolvimento do ego. Segundo ele, compulsão à repetição é inerente à evolução do ego, ou seja, o desenvolvimento normal implica em 'conflitos típicos' que, no limite, geram transtornos de adaptação. Hartmann dá um valor filogenético aos sintomas neuróticos, pois, enquanto tentativas malogradas de adaptação, são necessários para a evolução biológica. Para descrever o limite do valor adaptativo da pulsão de morte, se remete a Freud (1920), quando descreve processos nos quais organismos unicelulares abandonados se destroem, devido ao produto de seu próprio metabolismo. Mas o autor afirma que, quando elaborados adequadamente, distúrbios de adaptação podem ter 'alcance adaptativo'. O termo 'adaptação' inclui outros do gênero como 'estabilidade' e 'efetividade' de uma pessoa, que dependeria da ordenação, dentro do ego, de funções adaptativas por processos de diferenciação e síntese, e não somente pela 'força do impulso instintivo' e 'tolerância à tensão' que, segundo ele, definem habitualmente a 'força do ego'.

Por fim, no curso da evolução, uma progressiva internalização de funções com fator regulador do ego, constitui o denominado 'mundo interno', situado entre as instâncias receptoras e efetoras. 0 mundo interno tem utilidade biológica na adaptação, diferenciação e síntese, principalmente pelo maior controle da realidade que propicia. Os mecanismos de defesa seriam determinados em parte constitucionalmente, por interferência de processos de maturação do sistema nervoso central, e ocorreriam em um momento posterior em relação à diferenciação entre ego e o outro - segundo o autor esta é mais uma das justificativas para a existência da 'área sem conflito do ego'.

III.1.9. Algumas diferenças nas formulações dos teóricos pós-freudianos 
Sobre o uso do termo self , André Green (2003) discorre de forma elucidativa, quando afirma que prefere o uso do termo "sujeito". Afirma que o termo sujeito merece reivindicar um lugar como conceito, pois é condição necessária para se formar um relacionamento com o outro. Recorrendo a perspectiva psicanalítica, este autor afirma que a idéia de self remete a uma totalidade inacessível, ou se funda em uma idéia de unidade conquistada por meio de uma harmonia. Ele reafirma que Freud fundou a psicanálise sob a idéia de conflito e repressão, e, portanto sob a égide do inconsciente. No mesmo sentido, Green afirma que discorda da noção de 'representação do self '. Segundo seu ponto de vista, o ego não pode olhar para si mesmo e não se deve confundir a 'imagem corporal' com ego. 0 ego seria apenas um agente de transformação que se relaciona com a realidade e tem acesso à motilidade, de modo a promover a ação. De fato, o corpo, conectado com o encéfalo e com o mundo dá o tom motor a toda experiência, processada também por órgãos específicos sensoriais: 'o Eu se situa entre o sensorial e o motor no corpo'. Segundo o ponto de vista a ser desenvolvido neste trabalho, determinada sinestesia ou processos sensoriais sutis acompanham todo ato psíquico ou volitivo. Estes processos funcionam como um 'campo sensorial' que inscreve qualidades à experiência e esta seria a base somática da experiência no mundo.

Por outro lado, o que vincula o sujeito é a identificação, que como demonstrou Lacan, teria o papel de capturar o ego. Segundo Roudinesco e Plon (1998) o self como descrito na escola inglesa winnicotiana tratava de acrescentar à segunda tópica freudiana um complemento fenomenológico da pessoa ou do ser. "O self serviu então para delimitar a dimensão narcísica do sujeito, estivesse essa sadia ou destruída e fosse o self falso ou verdadeiro" (pg700). De fato, alguns autores consideram que o narcisismo primário foi colocado como instância especial de investimento tanto pela escola inglesa winnicotiana, 
quanto pela escola norte americana Self Psychology, desenvolvida por Kohut, a partir da psicologia do ego.

0 que falta na teoria que inclui o self, segundo o ponto de vista de Green, seria o paradoxo, ou seja, ser ao mesmo tempo o mesmo e diferente, além de depender intrinsicamente do Outro para sua constituição. Ele afirma: "O reconhecimento do sujeito daquilo que ele é composto e do que tenta alcançar, não pode ocorrer a não ser que ele seja reconhecido por um outro sujeito - o Outro - que é marcado por faltas correspondentes, mas está apto a olhar para o sujeito com a capacidade para reunir alguns dos fragmentos as partículas e pedaços de sua história - que a luta do ego falhou em integrar. Para isso, se a identificação é necessária, deve também ser observado que tudo isso não é suficiente, assim como compaixão não é suficiente para curar nossos pacientes” (Green, 2003, pág 18).

Argumentos contra a presença de um núcleo central do sujeito: o núcleo central ausente. Segundo Green, a escritura seria a comunicação com o ausente de forma oposta à palavra, tomada na presença. De forma similar, a psicanálise tentaria criar o artifício de uma presença ausente, ou uma ausência na presença. A escritura também trabalha esta dimensão da ausência e apenas o texto recria uma quase-presença ou quase ausência, assim como ocorre entre analista e analisando. Para entender a estrutura que oscila entre a perseguição e o luto, entre o presente e o ausente se remete à imagem do sujeito refletida no espelho - ele e seu duplo - e, por outro lado, o sujeito e nenhuma imagem sem qualquer representação: ele está ausente. Segundo Green sua teoria do duplo e do vazio permite ressaltar o papel da clivagem (entre corpo e pensamento, afeto e representação) enquanto o ou "aparelho vazio" no qual se atua 'narcisismo negativo'.

Onde estaria a fonte da integração, senão no outro?

Segundo Roudinesco \& Plon (1997) "para os ingleses tratava-se de acrescentar à segunda tópica freudiana um complemento fenomenológico da pessoa ou do ser, isto é, 
uma instância da personalidade constituída posteriormente ao eu, numa relação com a mãe e numa relação com o semelhante. 0 self serviu então para delimitar a dimensão narcísica do sujeito, estivesse essa sadia ou destruída e fosse o self falso ou verdadeiro". (pg700) De fato, alguns autores consideram que o narcisismo primário foi colocado como instância especial de investimento tanto pela escola inglesa winnicotiana, quanto pela escola norte americana Self Psychology, desenvolvida por Kohut, a partir da psicologia do ego

\section{III.1.10. Imagem corporal}

A capacidade de perceber a si mesmo separado do outro pode ser identificada em recém-nascidos, segundo estudo desenvolvido por Rochat and Hespos (1997). Bebês têm capacidade inata para discriminar entre estimulação externa e auto-estimulação, pois identificam quando seus dedos randomicamente tocavam suas bochechas de um toque externo, ou seja, os bebês apresentaram de forma significativa mais respostas de rotação de cabeça com lábios abertos em busca da mamada quando a estimulação foi feita pelo experimentador, comparada com a deles próprios.

Este sentido inato de 'eu corporal' pode ser investigado em termos de imagem corporal, em casos de pacientes que sofrem dor em membros fantasmas. A imagem corporal quando um membro do corpo foi mutilado está presente em termos de representação somática como se ainda fosse completo - o cérebro entende que o membro mutilado tem vida. Sujeitos reportam sensações táteis vívidas do membro fantasma quando vêem o experimentador tocar na imagem do braço contralateral ao espelho. A partir da imagem criada pelo braço contralateral, o paciente que antes sentia dores no membro fantasma deixa de senti-las (Ramachandran, 2002). A informação visual de que o membro existe se contrapõe à informação proveniente da área somatossensorial de que ele não existe. Com isso o cérebro compara informações e decide pela somatosensorial, de que o 
membro de fato não existe, e, portanto não pode haver atividade (que gera dor) naquela região somatosensorial. Isto demonstra que o cérebro é facilmente enganável. A imagem corporal, ou o ego corporal, portanto, é uma construção do encéfalo, vulnerável às diversas experiências sensoriais. Além de facilmente enganável, este dado apresenta o que poderia se chamar 'papel do negativo' na constituição da imagem corporal, ou seja, colocando o problema por outro ponto de vista, ou seja, apresentando uma ilusão perceptiva, o cérebro pode decidir sobre a verdadeira natureza do fenômeno somatosensorial. Também na transferência, opera fora do sujeito um teatro interno de relações de objeto, e a partir desta visualização, ele pode redimensionar seus afetos de forma apropriada.

Outros aspectos importantes do estudo demonstram que as fronteiras entre euoutro e a experiência de ser um em si e na relação com o outro é de fato bastante vulnerável às diversas experiências sensoriais, especialmente sensório-motoras e visuais. Ou seja, posso acreditar, depois de algum treinamento baseado em uma ilusão visual, que meu corpo se extende até a mesa, ou a um braço de cadeira (Ramachandran, 2003).

A capacidade de representarmos o corpo em termos cerebrais é muito precoce senão de origem inata e se desenvolve como consequência da interação sistemática entre inputs táteis, proprioceptivos e vestibulares, assim como entre estes inputs e a percepção visual da representação dos movimentos de seu próprio corpo e do corpo de outras pessoas. Lesões cerebrais podem induzir profundas mudanças na maneira como o corpo é percebido e representado (Berlucchi, 1997). Percepções de braço fantasma de amputados podem ser suprimidas por lesões parietais posteriores, mas não por excisões no córtex somatosensorial primário. 0 córtex insular está também envolvido com consciência corporal, particularmente na sua relação com aspectos emocionais, pois lesões insulares podem causar halucinações somáticas e estimulações elétricas próximas à insula induzem ilusões de mudanças da posição corporal e sensações de estar fora do próprio corpo. 
Pesquisas demonstram que há uma reorganização somatosensorial do membro amputado sendo que áreas adjacentes à área somatosensorial se apropriam da representação cortical original por inputs sensórios inerentes à representação da área adjacente. A constituição anátomo-funcional de mapas sensórios e motores no cérebro são altamente dinâmicos e sujeitos à interferência da experiência ainda no organismo adulto, também em áreas corticais que antes eram vistas como possuindo uma organização estereotipada e fortemente estabelecida.

O conceito de 'imagem corporal' pode ser parcialmente relacionado ao de self .

Dentre os autores seguidores da "Psicologia do ego" se destacam Joseph e AnneMarie Sandler. Estes autores consideram que a imagem do próprio self poderia ser consciente ou inconsciente, a percepção de si mesmo em um momento determinado, ou um conjunto de experiências que tem em comum uma identidade. 0 termo imagem não se reduz à experiência visual, mas se aplicaria a todas as modalidades sensoriais, incluindo a propriopercepção e a cinestésica. A "representação do self" diz respeito também a uma estrutura não relacionada com a experiência, mas com um 'esquema' ou uma 'imagem corporal'. Segundo estes autores, a afirmação de Freud: “o Eu é sobretudo um Eu corporal”, significa que "a representação do self é sobretudo uma representação de um eu-corpo". Ainda segundo a leitura de Sandler, na obra de Hartmann e de Jacobson subentende-se que o narcisismo é o amor pelo self ou por sua representação psíquica, enquanto que estrutura psíquica organizada é dotada de uma variedade de funções. A psicologia do ego, portanto, preocupou-se com a estrutura do ego, retirando da discussão a vida pulsional que originariam as relações objetais. Hartmann (1950), por sua vez, traçou uma diferença entre ego e self, na qual o ego seria uma organização mental objetivamente descrita, enquanto que o self seria uma representação investida no narcisismo. Esta distinção 
permitiu o desenvolvimento da chamada psicologia do self, que teve como pivô os trabalhos de Heinz Kohut. 0 termo self surgiu com o intuito de diferenciar o eu como instância psíquica (traduzido do inglês por ego) do eu como a própria pessoa, mas Kohut empregou Self para designar uma instância narcísica da personalidade, ou seja, uma 'representação de si por si mesmo', ou um 'auto-investimento libidinal' (Roudinesco \& Plon, 1997). Joseph Sandler entende que o conceito de representação, por um lado se vincula à experiênca subjetiva, e por outro ao que poderia ser denominado como “organização não experiencial". A criança, no decorrer do seu desenvolvimento vai formando a representação do próprio self, inicialmente ligado à satisfação de suas necessidades e posteriormente criando esquemas de muitas outras coisas, atividades e relações a partir da interação com o mundo externo. Sandler propõe a distinção entre 'representação de self' e 'representação de objeto', e seus processos correspondentes, sendo que as identificações modificariam representações do self e as introjeções permitiriam que objetos tornem-se 'introjectos'. Esta diferença fundaria a separação entre processos identificatórios e introjetivos.

\section{III.2. Empatia na Fenomenologia}

A superioridade da visão marca o que alguns autores denominam de imperialismo do olhar, e tem caracterizado a tradição científica e filosófica ocidental. É considerada um sentido superior pois ao mesmo tempo que une, separa, torna visível a diferença entre o ser do homeme o ser das coisas. Na antiguidade, sua superioridade dependia ainda do fato de possibilitar a theoria, ou a contemplação, o conhecimento "desinteressado" que permite, colocar-se à distância das coisas e não ser, desse modo, subjugado por elas. Tal situação permite hierarquizar os diversos sentidos em função do seu maior ou menor grau de "espiritualidade", começando pela vista - o sentido "mais espiritual", "mais perfeito" e "mais 
universal" - e passando pelo ouvido, pelo olfacto, até ao tacto e ao gosto, sendo estes dois últimos os sentidos mais materiais.

A fenomenologia desenvolve uma "ontologia da presença", na qual a visão e a corporalidade assumem papéis fundamentais.

Husserl, seguindo o modelo cartesiano de investigação da consciência (em "A defesa da empatia" elaborada na 5a Meditação Cartesiana), está interessado na experiência que posso ter do outro, e o problema do conhecimento do outro é o problema da constituição em mim deste objecto singular que é outro-eu. Para Husserl o conhecimento do outro em mim se apresenta na intersubjectividade e intencionalidade atos da consciência (síntese noesis-noema, ou de ato intencional e visado). As percepções singulares do fluxo temporal são unidas continuamente, e por esta continuidade dá-se a unidade de identificação na unidade fenomenológica. 0 ato de identificação, é uma consciência de objetividade que faz aparecer um novo objeto, mantém uma relação com suas partes e se dá como uma unidade abrangente de ato. 0 outro aparece na empatia como apresentação, mas como no cubo, não sua 'presentação'. O outro é outro porque suas vivências não podem ser dadas de forma original e o outro é primeiro em si outro eu. A comunidade de nômadas formada pelos vários Eus constitui um só e mesmo mundo da minha experiência do outro.

Na leitura de Merleau-Ponty, a fenomenologia, com o conceito transcendental de Edmund Husserl (1859-1938), sugere um rompimento da familiaridade com o mundo para que nessa ruptura possamos perceber seu surgimento imotivado - a melhor forma da redução fenomenológica é admirar-se frente ao mundo e conceber o sujeito como transcendência em direção ao mundo. Porém, como estamos no mundo a redução nunca será completa. "Isso também significa que a filosofia não deve considerar-se a si mesma como adquirida naquilo que ela pôde dizer de verdadeiro, que ela é uma experiência renovada de seu próprio começo, que toda ela consiste em descrever este começo e, enfim, 
que a reflexão radical é consciência de sua dependência em relação a uma vida irrefletida que é sua situação inicial, constante e final” (Ponty, 1994, p.11). Sua ambição é igualar a reflexão `a vida irrefletida da consciência. A contribuição fundamental de Merleau-Ponty, é refundar a experiência da percepção do mundo, em detrimento do cogito cartesiano no qual a certeza da existência do si-mesmo decorre da análise da experiência da consciência. Merleau-Ponty, no texto Fenomenologia da Percepção descreve um novo sujeito da sensação, no esforço genuinamente fenomenológico de "reencontrar um contato ingênuo com o mundo para dar-lhe enfim um estatuto fenomenológico" (Idem, p.01). 0 primeiro passo para entendermos como a intersubjetividade pode ser compreendida é compreender seu conceito de percepção - ele nos convida a voltar "aquilo que pensamos saber o que é”, “como o sentir, ver e ouvir - e tomar estas palavras como problemas que se colocam `a nossa própria experiência". Segundo Merleau-Ponty o problema da análise reflexiva é o de ignorar o problema do outro assim como o problema do mundo.

Jaspers criou seguidores na psiquiatria humanista como Kurt Schneider, para quem atender um paciente dependia não de uma análise de conteúdo mas da vivência e seus modos, que permitem, também, um diagnóstico. A crítica da psiquiatria de fundamento fenomenológico de Jaspers se dirige a um movimento objetificante da psicopatologia krapeliniana e perdeu produtividade com a segunda grande guerra e com o nazismo (Jaspers, p. X, 1993).

Na psiquiatria de Jaspers, a relação médico-paciente, ou do "mesmo com os outros" está presente por um vínculo de destino de "mesmo nível”, em plena abertura, no qual a “comunhão existencial” permite, na reciprocidade, o esclarecimento. Ele afirma: Médico e doente são ambos seres humanos e como tais são companheiroa de destino. 0 médico não é apenas técnico nem apenas autoridade, mas existência para existência, essência humana perecedora com os outros". (Jaspers, 1993, p.879) Da experiência de comunhão no amor e 
em um destino vital comum, através das fases da idade, resulta a transparência no tornarse o "mesmo". Segue que os procedimentos psicoterapêuticos quando confrontados `a esta experiência, são limitados teorica e autoritariamente. A relação de autoridade médicopaciente é inerente à si mesma, e apesar de em alguns casos ser benéfica, pode alcançar outro patamar (Idem, p. 884).

Sobre isso, Jaspers afirma: "a compreensão psicológica trata de entender a genesis dos conteúdos psíquicos em função da história utilizando a capacidade humana de colocarse no lugar do outro. 0 instrumento intelectivo para consegui-lo é a compenetração (Einfühlung )." (Jaspers, p. IX, 1993) 0 conceito de "compenetração" acompanha o conceito de "concepção de mundo" (Weltanschauung), que procede de Dilthey.

\section{III.2.1. Edith Stein}

Sob orientação do filósofo Edmund Husserl, Edith Stein em 1916 defendeu a tese de doutorado Zum problem der Einfuhlung "Sobre a empatia". Nascida na Alemanha em 1891 e morta vitima do nazismo em Auschwitz, 1942, pedagoga, fenomenóloga posteriormente tornou-se filósofa católica convertida. Segundo Garcia, quem visita o arquivo Carmelita Edith Stein de Colônia - Alemanha percebe quão variada é a produção da filósofa desde quando discípula de Husserl até as obras místicas escritas no claustro. Segundo documento elaborado por Husserl, o mérito do trabalho de Edith sobre empatia foi apresentar uma fenomenologia da empatia, e esclarecer a origem fenomenológica das idéias de 'corpo próprio', 'alma', 'indivíduo', 'personalidade espiritual', 'comunidade social' e 'estrutura comunitária'. No período de elaboração da tese, Stein considerava-se atéia, mas após sua conversão ocorreu uma profunda mudança da autora e de sua obra. Porém, neste trabalho já se revela "a afirmação importante para a concepção realista e cristã da pessoa, de que o "eu" não se apresenta nunca na forma do abstrato cogito cartesiano e kantiano, mas como 
um ato de presença em qualquer lugar ou "onde" (wo), isto é, como se diz hoje, "colocado em situação"'”. No capítulo 4, onde trata da pessoa pode-se antever o conceito de alma: princípio vivente onde se encontra uma 'potência vital superior' que faz com que seja experimentado o processo causal. Uma 'intenção' determina a relação entre indivíduo e comunidade ou formas sociais. Segundo Stein, "tem-se uma sociedade quando uma pessoa contrapõe a si mesma como sujeito a outra, considerada objeto e tentam entender-se. Quando o sujeito reconhece no outro um sujeito amigo temos uma comunidade. Quando a liberdade pessoal é destruída a fonte da vida comunitária também é destruída." O Estado não cria a liberdade pessoal, mas deve protegê-la e estimulá-la organizando relações sociais. A religião tem absoluto primado sobre todas as esferas, e é dever do Estado favorecer para que as pessoas consigam o Bem espiritual e tenham liberdade de religião e de culto. Todas as criaturas e não só o homem são imagem de Deus." (in Garcia)

\section{III.2.2. Emmanuel Levinas}

Dentre os autores da fenomenologia francesa da década de 40, além de MerleauPonty destaca-se o filósofo Emmanuel Levinas (1905-1995). Na fenomenologia elaborada por Levinas a filosofia ocidental, tendo as suas raízes no logos, na razão, foi, na maioria das vezes, uma ontologia: "uma redução do Outro ao Mesmo" (Levinas, 2008, p. 30) No entanto é nesta posição crítica do filósofo que também se descobrem alguns dos mais importantes mistérios da filosofia de Levinas - como é que é possível para o Eu reconhecer o Outro, sem tentar compreendê-lo, capturá-lo ou transformar a sua exterioridade?

“As diferenças entre mim e Outrem não dependem de propriedades diferentes que seriam inerentes ao "eu", por um lado, e a Outrem, por outro; nem de disposições psicológicas diferentes que tomariam o seu espírito a quando do encontro. Tais diferenças tem a ver com a conjuntura Eu-Outrem, com a orientação inevitável do ser a partir de si 
para outrem". (Levinas, 2008, p.211) "Para que a exterioridade possa apresentar-se a mim, é preciso que, enquanto exterioridade, ela ultrapasse os "termos" da consciência vital, mas que, ao mesmo tempo, enquanto presente, não seja mortal `a consciência. Esta penetração de um sistema total em um sistema parcial que não o pode assimilar é o milagre. A possibilidade de um pensamento é a consciência do milagre ou a admiração."

A presença do outro se remete `a transcendência do rosto do outro e `a relação originária de responsabilidade. A ética levinasiana não aceita a liberdade e a autonomia como princípio fundante da subjetividade - a ética tem como característica fundamental a responsabilidade do 'mesmo' na instauração da justiça para com o 'Outro' que se encontra marginalizado. 0 rosto fala, mas dispensa a palavra. "A presença do rosto que vem de além do mundo, mas que me empenha na fraternidade humana, não me esmaga como uma essência numinosa, que faz tremer e se faz temer. Está em relação dispensando-se dessa relação equivale a falar. Outrem não aparece apenas no seu rosto - como um fenômeno sujeito `a ação e `a dominação de uma liberdade.” (Idem, p.210) (...) “O rosto em que outrem se volta para mim não se incorpora na interpretação do rosto. Ouvir a sua miséria que clama justiça não consiste em representar-se uma imagem, mas em colocar-se como responsável, ao mesmo tempo, como mais ou como menos do que o ser que se apresenta no rosto. “ (Idem, p.211)

\section{III.2.3. Breve exposicão da Hermenêutica em Dilthey}

Wilhelm Dilthey (1833-1911) pensa uma hermenêutica na qual interpretar é obter a compreensão do outro pela 'revivência' (Nacherlebnis) da sua experiência. A isso denomina “transposição empática" ou captação do sentido de expressões. Interpretar é captar o sentido das expressões corporificadas nas obras. Com que pressupostos se dá esse salto empático? Não por introspecção, como se fosse possível adentrar e imergir na 
subjetividade alheia.

A autocompreensão em face das realizações culturais assenta na revelação das semelhanças e diferenças, das variações e particularidades, que decorrem da interação social. Neste mundo cultural, construído objetivamente, a mente encontra a si própria e o $\mathrm{Eu}$ se redescobre no Tu. Mais uma vez, não em termos de encontro imediato de subjectividades translúcidas, mas por sobreposiççnao de um mundo partilhado.

Dilthey defende as ciências do espírito com métodos autonomos e harmonia com o seu objeto. Nas ciências do espírito, a base é a conexão da vida anímica como algo originariamente dado. "Explicamos" a natureza, "compreendemos" a vida anímica.

O conceito de empatia tornou-se "instrumento intelectivo" da compreensão psicopatológica na psiquiatria de fundamento fenomenológico de Karl Jaspers (Jaspers, 1913). Jaspers aceita a separação proposta pela hermenêutica filosófica de Dilthey que formulou a dualidade entre as 'ciências da natureza' e 'ciências do espírito'. Seu pressuposto considera que as ciências do espírito ou 'vida da alma' é compreendida (Verstehen) e as ciências da natureza explicam. 


\section{III.3. Empatia na neuropsicologia}

III.3.1. Teoria da mente e o senso de si-mesmo

Algumas pesquisas demonstram que os substratos neuroanátomo-funcionais do que denominam empatia e da teoria da mente são diferentes apesar de compartilharem áreas comuns (Vollm et al, 2006). De uma perspectiva evolutiva, a habilidade de 'teoria da mente' teria se desenvolvido para lidar com desafios sociais. Esta habilidade depende da possibilidade de refletir sobre si-mesmo. Alguns autores caracterizam o senso de simesmo como resultado de esquemas, como Piaget denominou schemata, que diz respeito às habilidades, traços e atitudes que dirigem nosso comportamento, escolhas e interações sociais (Johnson et al, 2000). Estes autores consideram que a auto-consciência pode estar prejudicada em pacientes com lesões, por exemplo quanto à avaliação realizada por eles de suas capacidades, destoantes quando comparadas às avaliações feitas por outros. 0 senso de si-mesmo dependeria do desenvolvimento do córtex pré-frontal, e lesões nesta região confirmam esta hipótese, pois causam alterações da consciência de si-mesmo, necessária para interações sociais apropriadas, julgamento e planejamento. Também se observa que pacientes com este tipo de lesão tem problemas para avaliar o estado de mente do outro ou seja, não são capazes de ter 'teoria da mente'.

Segundo nossa perspectiva a teoria da mente está relacionada com a possibilidade de imaginar-se em determinada situação, portanto mais próxima da imitação. Depende da capacidade de simbolizar e de significar o outro e si mesmo. Nos parece importante discriminar os mecanismos implicados na empatia e na teoria da mente, no sentido de diferenciá-los.

Estudos de teoria da mente empregam testes psicológicos no intuito de investigar os estados mentais e diversos tipos de crenças sobre si mesmo. As clássicas vinhetas de 
Baron-Cohen (1985), por exemplo, incluem estórias nas quais os personagens afirmam sentenças que não devem ser compreendidas literalmente, mas sim no seu sentido figurado. Estes testes incluem a compreensão de ironia, metáforas, ou tarefas nas quais os participantes têm que explicar o estado emocional do personagem e suas intenções. 0 estudo desta habilidade é muito importante no entendimento de como se dá a representação interna do estado de mente do outro e de si próprio, habilidade implicada na constituição da identidade e na possibilidade de interação e convívio social.

A teoria da mente tem sido estudada em situações de desenvolvimento normal, e em desordens psiquiátricas, especialmente no autismo, psicopatia, esquizofrenia e transtorno de personalidade borderline (Tebatz van Elst et al, 2003). Baron-Cohen e colaboradores têm desenvolvido desde a década de 80 estudos que demonstram a relação entre teoria da mente e autismo (Baron-Cohen et al, 1985, 2001). Segundo seu ponto de vista, anormalidade na teoria da mente é a principal característica cognitiva do espectro autístico, como quando medida em tarefas de percepção do significado de expressões oculares (Baron-Cohen et al, 1995). A dificuldade para separar realidade de fantasia e para sustentar avaliações perceptuais pode ser estudada por apresentação e julgamento de estímulos ambíguos. Estudos recentes sobre autismo têm demonstrado que estes pacientes são pouco hábeis para imitar estímulos emocionais e supõe-se que esta dificuldade decorre da disfunção na integração das áreas responsáveis pelas funções neuropsicológicas como visual, motora, proprioceptiva e emocional (Williams et al, 2006). Segundo estes autores, a falha de integração prejudicaria o desenvolvimento da 'habilidade imitativa' uma função de 'teoria da mente'. Por outro lado, na esquizofrenia também se apresenta déficit em teoria da mente (Quintana et al, 2001). Estudos atuais em neuroimagem demonstraram que, quando comparado ao grupo controle, as imagens cerebrais dos esquizofrênicos têm aumento de ativação em regiões motoras e pré-motoras, mecanismos cerebrais 'não 
naturais' em tarefas de tomada de decisões dependentes de identificação de expressões faciais (Quintana et al, 2001). Este resultado tem grande importância para se entender o mecanismo de apreensão do estado emocional que se dá de forma natural em pessoas saudáveis, e de forma anômala nas desordens esquizofrênicas.

Paradigmas desenvolvidos com fMRI se utilizam de avaliações realizadas pelos sujeitos do experimento sobre eles mesmos, com itens como: "Fico bravo facilmente", “Frequentemente esqueço coisas", "Meu futuro será brilhante”. Resultados sobre a atividade do encéfalo durante este tipo de julgamento (Johnson et al, 2002) podem ser descritos apenas como relativos à uma tarefa cognitiva, sem, de fato incluírem o estudo da apreensão de si-mesmo pelos sujeitos do experimento.

Outra categoria de estudos inclui identificação de faces de si-mesmo comparadas às faces de conhecidos e de desconhecidos.

Inicialmente, partiremos de uma análise de resultados de estudos de neuroimagem sobre percepção de faces com conteúdo emocional.

Estudos de neuroimagem demonstram que networks similares no cérebro do receptor da imagem. A percepção visual de faces com expressão emocional dispara um padrão de atividade neural semelhante no observador e no sujeito observado (nao tem ref: Carr et al., 2003; Ekman and Davidson, 1993). Incluem-se estudos sobre dor (Jackson et al, 2005), nojo (Phillips et al, 1997; Wicker et al, 2003) e observação da experiência de toque (Keysers et al, 2004), sugerindo a ocorrência de uma experiência similar vivida pela dupla. Pacientes com lesões em córtex somatosensorial direito na área correspondente à face apresentam dificuldades em expressar e reconhecer expressões faciais emocionais (Adolphs et al 2000).

Como alguns estudos demonstram, a expressão facial, especialmente ocular, tem um papel proeminente na comunicação entre estados de mente. Estudos com primatas sobre 
eye gaze demonstram que a região periocular é usada em contextos sociais para transmitir informações sobre o estado emocional do indivíduo, e, portanto pode ser usada para reconhecer intenções de outros indivíduos (Ferrari et al, 2000).

De acordo com Ferrari et al (2000) a habilidade de seguir o olhar do outro é um estágio crucial no desenvolvimento do sistema de 'leitura-da-mente', que permite aos indivíduos compreenderem não apenas intenções motoras, mas também o que se está pensando. Portanto, os olhos foram metaforicamente descritos como 'janelas' para a mente dos outros (Ferrari et al, 2000).

Podemos supor que haja um 'contágio' do estado emocional do outro por meio da percepção de faces ou, mais especificamente, entre duas pessoas que trocam olhares. Por meio da análise de resultados de pacientes com lesões em área somatosensorial específica para face, que sofrem dificuldade de empatia, podemos também levantar a hipótese de que a geração de estados emocionais similares no observador de faces depende da atividade desta região somatosensorial, correspondente à região do corpo observada.

\section{III.3.2. Teoria da mente e fMRI}

Estudos neurocientíficos sobre emoção e comunicação de estados emocionais servirão também para definir o novo conceito de empatia. Apesar de diversas áreas cerebrais cooperarem para o processamento emocional, a região dorsomedial direita tem sido descrita em diversos estudos como responsável pela auto-referência e parece mais relacionada ao sentido de identidade (Fossati, 2003). 


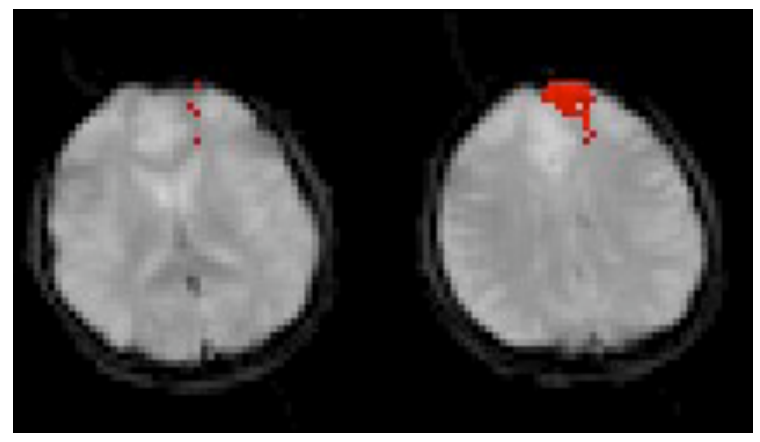

Exemplo de imagem do encéfalo mostrando região Dorsolaterofrontal e órbito-frontal em experimento piloto no qual o sujeito tinha que adivinhar o estado emocional do outro (Amaro E, Simone AD, Cesario A, 2007)

Cada vez mais tem se demonstrado o papel de um sistema neuronal específico denominado mirror system que permite que haja o 'contágio' de comportamentos. Um trabalho interessante desenvolvido com fMRI demonstrou que o contágio se inicia com atividade deste sistema, avaliado pela observação de fotos de pessoas bocejando, em contraposição às fotos de pessoas com expressões neutras.

Outras denominações para descrever a capacidade de representar o estado mental de si-mesmo e do outro incluem ToM (theory of mind), atribuição de estado mental, apreensão da instância intencional, mentalização, conhecimento reflexivo. 0 conceito de teoria da mente foi inicialmente usado por Premack e Woodruff (1978).

A capacidade de apreender o estado emocional ou as intenções do outro, nas neurociências depende do que tem sido denominado como empatia. Quando se contrapõe uma visão do self enquanto construção social versus uma visão naturalística, este conceito permite afirmar que o self emerge da atividade do cérebro com outros self s. A ligação entre self e outro estaria sujeita à capacidade para representar o outro, projetar pensamentos e sentimentos ao outro, sentir simpatia e se identificar psicologicamente com outros (Decety and Chaminade, 2003). Outra abordagem pressupõe que a capacidade de 
identificar-se com o outro deriva da possibilidade de tomar o outro como si mesmo, por meio de processos imitativos.

Segundo Meltzoff (2005), a imitação seria um equipamento inato supramodal de representação da ação e estaria intrinsicamente relacionado com o julgamento da intenção do outro. Segundo Meltzoff (2005), a chamada 'teoria da mente' ou mentalização (habilidade para apreender estados de mente do outro e de si próprio) dependeria de uma hipótese 'como eu', que seria o fundamento da identificação. Imitação de ações intencionais em primatas foi inicialmente compreendido como um precursor evolutivo dos mecanismos humanos de imitação, que seria fundamental na transmissão cultural. Segundo este autor, a capacidade imitativa humana permite que ele se identifique com seus co-específicos mais do que as outras espécies.

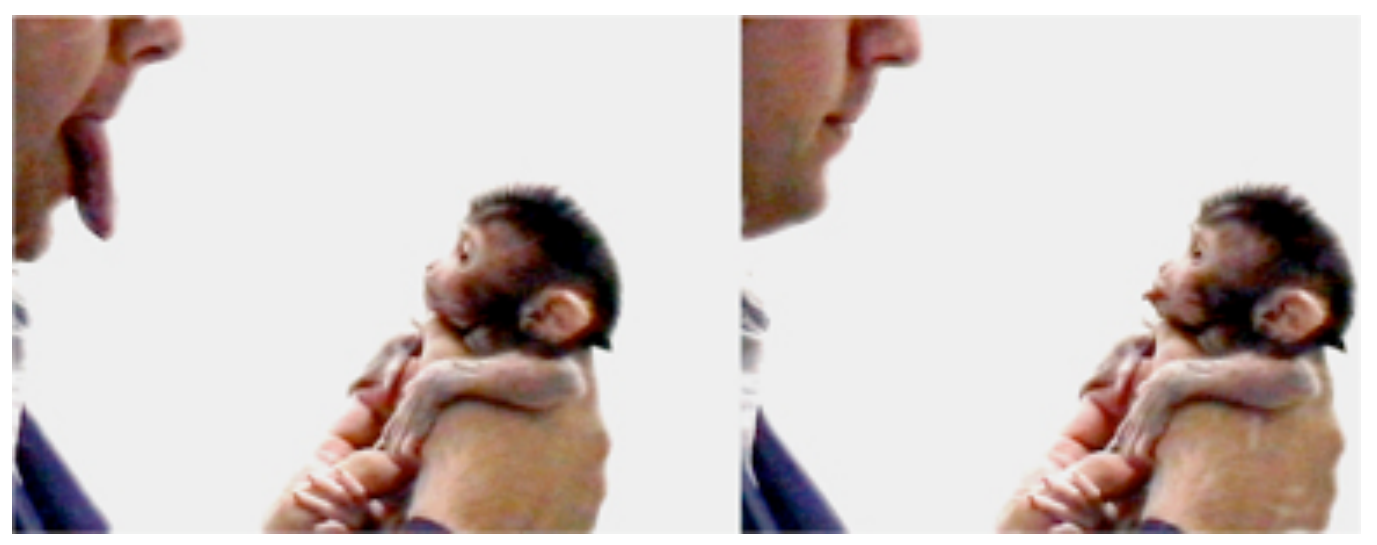

(In: Singer, 2006)

Diversos grupos de pesquisa defendem um sistema neuroanátomo-funcional cortical na percepção social e em tarefas cognitivas como perceber "visadas" (eye gaze) e o denominam como 'sistema cerebral social' (Johnson, 2005).

III.3.3. Neuron system 
Neurônios espelho foram descobertos e nomeados há aproximadamente 10 anos (Gallese et al, 1996). Descobriu-se que uma classe de neurônios que disparam quando os chipanzés executam ações dirigidas a metas como apanhar um objeto e também quando observam outros indivíduos executando ações similares. Os neurônios espelho foram descobertos em primatas em região parietal posterior, reciprocamente conectado com a área F5 (Fogassi and Gallese, 2001). Em humanos, a área pré-motora que compõe o sistema de neurônios espelho foi ativada durante a execução e a observação de ações, mas também durante atividade de compreensão da intenção dos outros em tarefa de observação de ações (Iacoboni et al, 2005). Em termos de neuroanatomia comparativa, a area F5 que demonstra propriedades especulares no cérebro de primatas corresponderia à àrea 44 , de Broca, no cérebro humano. Este dado é corroborado por achados que incluem a participação de áreas de linguagem no chamado Human Mirror Neuron System (HMNS) como estudo que demonstra atividade da área de Broca associada à atividade da área motora primária M1 (Nishitani, 2006).

Imitação de ações intencionais em primatas foi inicialmente compreendido como um precursor evolutivo dos mecanismos humanos de imitação, que seria fundamental na transmissão cultural. Segundo este autor, a representação motora de uma ação voluntária evocaria a representação sensória das suas conseqüências e a imitação seria adquirida por meio de um mecanismo que relaciona a representação visual do movimento a ser imitado com a subsequente re-ativação motora das representações (Iacoboni et al, 2001). Posteriormente o conceito foi ampliado a partir de pesquisas em humanos, como as que utilizam técnicas modernas de imagemanento do encéfalo, como a ressonância magnética funcional. Predição de ação em humanos também ativa as mesmas regiões implicadas no reconhecimento da ação, com reconhecimento visuo-espacial e antecipação da ação por áreas somatosensoriais (Lamm et al, 2007). 
Em um estudo com RMf este mesmo grupo de pesquisadores apresentou resultados que segundo eles corroboram a relação entre empatia (observação de emoções faciais) e imitação de expressões faciais (Carr et al, 2003). A imitação seria um equipamento inato supramodal de representação da ação e estaria intrinsicamente relacionado com o julgamento da intenção do outro (Meltzoff, 2005). Meltzoff (2005) afirma que este mecanismo seria a base da habilidade de teoria da mente, que dependeria do que este autor denominou de hipótese 'como eu'.

Porém, é fundamental que esta discussão seja comparada com discussão sobre a forma como ocorre a transmissão de um estado emocional entre dois sujeitos.

$\mathrm{Ou}$ seja, diversas evidências demonstram que o aspecto emocional do comportamento do outro é compreendido por meio dos mesmos mecanismos responsáveis pela geração da emoção (Adolphs, 2002). Novamente, o sistema de reconhecimento de emoções é também específico para a qualidade da emoção como, por exemplo, na emoção de nojo se ativa o córtex amigdalar e estruturas que participa da experiência somatosensorial (Adolphs, 2002).

\section{III.3.4. Empatia como afeto e emoção}

Damásio define emoção como a combinação de um processo de avaliação mental, simples ou complexo, com respostas em sua maioria dirigidas ao corpo, resultando num estado emocional do corpo, mas também dirigidas ao cérebro por núcleos neurotransmissores localizados no tronco cerebral. Da mesma forma Mark Solms (2002) define emoção como uma função estado-dependente, que reflete modificações no corpo comunicado com estruturas de monitoramento somático no encéfalo, mas com a principal característica, que a difere de outras modalidades sensoriais: ser uma percepção subjetiva, ou percepção do estado do sujeito e não de um objeto do mundo. 
Na tentativa de distinguir emoção de cognição LeDoux (1996) caracterizou dois tipos de emoção: (1) as emoções básicas como inatas ou primárias, de caráter mais biológico e herdado e (2) as emoções secundárias derivadas da experiência e de característica mais social. Com relação a esta diferenciação, Damásio (1998) considera: “a natureza, com sua mania de fazer economia, não selecionou mecanismos independentes para exprimir emoções primárias e secundárias. Limitou-se simplesmente a permitir que as emoções secundárias se exprimissem pelo veículo já preparado pelas emoções primárias".

A descoberta do sistema límbico possibilitou o aprofundamento do papel das estruturas cerebrais no comportamento emocional. Segundo Marcel Mesulam (2000), o circuito neuroanatômico do comportamento emocional e memória envolve as seguintes regiões: (1) para-límbicas como região órbito-frontal, pólo temporal, insula anterior, cingulo e giro parahipocampal e (2) as regiões límbicas: complexo hipocampal (giro denteado, CA1-4 e áreas subiculares), córtex olfatório primário, septum e complexo amigdalóide.

Dentre as estruturas do sistema límbico, a principal estrutura envolvida em drive e afeto é o complexo amigdalóide. A amígdala é conhecida como criticamente envolvida na expressão de respostas defensivas inatas (LeDoux, 1996). Lesões no núcleo lateral da amígdala geram uma síndrome denominada "raiva septal" (septal rage) devido a uma hiperdefensividade. Isto está relacionado com a atividade de neurônios GABAérgicos localizados no núcleo septal lateral da amígdala, que fornecem inputs inibitórios às reações defensivas. Estudos de ablações de amígdala de macacos (Mesulan, 1993) demonstraram que esta estrutura é pivô no controle do drive e afeto. Estudos da síndrome de Klüver-Bucy, em que a amígdala está privada do seu input cortical demonstraram que esta estrutura é fundamental para a associação da resposta emocional adequada aos objetos externos 
(Mesulan, 1993). Remoção das amígdalas em ambos os hemisférios amança animais e humanos, os estudos relacionam esta alteração comportamental com diminuição da habilidade para discriminar aspectos afetivos dos estímulos (Pincus \& Tucker, 1985). Por sua vez, o hipotálamo parece também implicado neste sistema, a zona hipotalâmica mesial é crítica para expressão de comportamento defensivo inato (Canteras, 2002).

Os lobos frontais têm também grande participação no comportamento emocional, principalmente a região órbito-frontal que recebe informações provenientes do sistema límbico sobre estados internos. Shore (1994) investigou em profundidade a maturação do córtex órbito-frontal de hemisfério direito incluindo seus inputs e outputs, circuitarias que passam pelas estruturas do tronco cerebral e sistema límbico. 0 córtex órbito-frontal regula as estruturas subcorticais por um sistema inibitório que controla o sistema autonômo (incluindo o sistema nervoso visceral), ou seja, controlando manifestações somáticas da emoção como respiração, sudorese, pressão arterial, etc. e, por outro lado, tem uma função importante na motivação, estimulação do sistema locomotor e na administração dos aspectos prazerosos da interação social, devido ao sistema dopaminérgico.

Esta região quando lesionada gera distúrbio sutil da identidade: parte do comedimento, inibição, precaução é destruída e os pacientes reagem impulsivamente tanto aos estímulos internos como aos externos. Oliver Sacks (Sacks, 1995) descreve uma sensibilidade passiva e indiferenciada entre ambiente e o "eu" em pacientes com lesão órbito-frontal na qual a mente passa a ser escrava de sensações passageiras, como na "síndrome de dependência ambiental". Este tipo de lesão também altera a libido ou outras funções viscerais devido à conexão estreita da região órbito frontal com o diencéfalo que regula funções como sono, apetite e libido (Sacks, 1995). Segundo Damásio (1998), a conexão sistêmica entre os córtices frontal ventromedianos bilaterais e amígdala é 
extremamente importante para o "comportamento emocional", pois as regiões frontais anteriores especialmente mediais correlacionam informações de fontes internas e externas, conscientes e inconscientes, fontes de estocagem mnêmica e informações de centros de arousal visceral. A descoberta de uma grande concentração do receptor de serotonina (5-HT) do tipo 2 somente nestas regiões do cérebro confirma esta hipótese na medida em que o aumento de serotonina reduz a agressão e favorece o comportamento social.

Segundo Damásio (1998), a rede de circuitos do sistema límbico principalmente a amígdala e o cíngulo são responsáveis pelo processo básico do comportamento emocional, ou seja, pelas emoções primárias. Outros autores têm demonstrado que outras áreas, especialmente do tronco cerebral, chamada PAG (periaquaductal gray matter) e o núcleo dorsal da rafe, desempenham um papel fundamental na modulação de respostas emocionais relacionadas à dor e à agressão, e são as principais fontes de serotonina do sistema límbico e do córtex cerebral. 0 comportamento de "luta-ou-fuga" pode ser eliciado por estimulação da PAG em ratos, e em humanos a estimulação gera medo e um senso de perigo com sintomas autonômicos da ansiedade relacionados, como tensão muscular, tremor e aumento da pulsação. Estes sintomas são atenuados pelo uso de benzodiazepínicos, e opióides endógenos na PAG produzem um efeito analgésico.

Outra região importante do sistema para-límbico implicado na emoção de característica primária é o pólo temporal, com diversos relatos de manifestações de irritabilidade e agressividade subjacente à epilepsia de lobo temporal (Devinsky \& Bear, 1984; Pontius, 1989) nos quais são descritos rompantes de agressividade, mudanças de personalidade ou ainda alteração de humor (Blumer, 1975; Heilman; Pincus \& Tucker, 1985). 
Em contrapartida, as emoções secundárias seriam "adultas", pois se iniciariam à medida que começamos a ter sentimentos e a formar ligações sistemáticas entre categorias de objetos e situações com determinadas emoções primárias. Nesse sentido a rede envolvida na sua ocorrência deve ser ampliada para além do sistema límbico, envolvendo os córtices pré-frontais e somatossensorial.

0 mecanismo de funcionamento cerebral envolvido na emoção secundária foi apresentado por Damásio pela descrição do que ocorre nas situações como da notícia da morte de um colega. 0 processo se inicia com as considerações conscientes que lhe ocorrem em relação à determinada pessoa ou situação expressas como "imagens" (ou representações) organizadas num processo de pensamento. Essa seria a avaliação cognitiva do conteúdo do acontecimento. Algumas das imagens evocadas não são verbais como a aparência da pessoa em determinado lugar enquanto outras são verbais como palavras e frases relativas a atributos, atividade, nomes, etc. 0 substrato neural de imagens (ou representações) tem especificidade quanto ao tipo do material sendo topograficamente organizadas com ocorrência em diversos córtices sensoriais como visual, auditivo e outros. Essas representações foram criadas sob o controle de "representações dispositivas" distribuídas nos córtices de associação. Em um nível não consciente, redes no córtex préfrontal reagem automática e involuntariamente aos sinais resultantes do processamento das imagens. De forma automática e involuntária, as disposições pré-frontais comunicamse com a amígdala e com o cíngulo anterior. 0 cíngulo responde: (a) ativando os núcleos do sistema nervoso autônomo e enviando os sinais ao corpo e às vísceras que são colocadas no estado associado ao tipo de situação; (b) enviando sinais ao sistema motor, de modo que a musculatura esquelética complete o quadro (c) ativando os sistemas endócrino e peptídico e por último (d) ativando, com padrões especiais, os núcleos neurotransmissores não específicos no tronco cerebral e prosencéfalo basal, os quais liberam então as mensagens 
químicas em diversas regiões do telencéfalo como gânglios da base e córtex cerebral. As mudanças causadas por (a), (b), (c) afetam o organismo, causam um "estado emocional do corpo" e são posteriormente representadas no sistema límbico e somatossensorial. As mudanças causadas por (d) que não ocorrem no corpo propriamente dito, mas num grupo de estruturas do tronco cerebral relacionado com a regulação do corpo, têm um impacto muito importante no estilo e eficiência dos processos cognitivos e constitui uma via paralela de resposta emocional.

\section{III.4. Empatia na neuropsicanálise}

A própria investigação da encéfalo depende da posição do observador, ou seja, da forma pela qual ele relaciona os resultados obtidos (discussão dos dados) e, principalmente, a maneira como estes dados foram obtidos (protocolo de pesquisa), com pressupostos e metodologia específica (paradigma).

Diversos estudos com paradigma de provocação de emoção partem da entrevista feita com os pacientes para elaborar o material a ser usado durante o paradigma experimental. Um dos primeiros estudos deste tipo foi desenvolvido por Howard Shevrin, no qual, por meio de sessões terapêuticas com os pacientes identificou palavras relacionadas à experiência consciente de um sintoma ou relacionadas ao conflito inconsciente subjacente aos sintomas (Shevrin 1997). Estes dados serviram para uma investigação neurofisiológica do tipo de processamento efetuado pelo cérebro com estímulos apresentados subliminarmente, relacionados depois ao funcionamento do sistema inconsciente comparado ao consciente. Experimentos demonstrando "knowledge without awareness" se focaram em estudos com percepção subliminar. Reações afetivas frente a estímulos apresentados com durações diversas demonstraram que o impacto 
emocional de determinado estímulo é tão mais forte quanto menor for o tempo de exposição.

Alguns elementos apresentados na concepção de aparelho psíquico desenvolvida por Freud têm semelhanças com o processamento das emoções primárias e secundárias. Especialmente, ao descrever o processo primário e o processo secundário. Segundo ele, o aparelho psíquico é constituído por uma rede ampla de imagens ou representações de vivências inscritas (memória) que compõe uma matriz segundo a qual o sujeito decodifica os estímulos internos e externos. Luiz Hanns (1999) descreve esta matriz como: "o campo psíquico pelo qual pulsões, ou melhor, as manifestações dos estímulos pulsionais, se movimentarão". Nesta matriz operam duas formas de funcionamento, o processo primário, mais arcaico, que funciona sob a forma de imagens e afetos e outro, processo secundário, mais complexo que funciona sob a forma da linguagem verbal (palavras). 0 processo primário qualifica as experiências afetivamente como prazer ou desprazer. De forma geral (no adulto e fora de certas patologias), o processo primário prevalece no inconsciente e permite uma mobilidade muito maior das intensidades de investimento pulsional, tendo como características a atemporalidade, e os mecanismos de deslocamento e condensação das representações e substituição da realidade exterior pela realidade psíquica. 0 processo de deslocamento permite que uma representação entregue seu investimento à outra, pela condensação a representação pode tomar para si o investimento íntegro de muitas outras, estes processos são indícios do processo primário. 0 processo secundário ocorre no sistema pré-consciente, no qual se efetua um ordenamento temporal das representações, a introdução de uma ou diversas censuras, o exame de realidade e o princípio de realidade - a memória consciente parece depender do sistema pré-consciente.

Termos como 'afeto inconsciente', 'sentimento inconsciente', portanto, remetem aos destinos do fator quantitativo da moção pulsional, como conseqüência da repressão. 0 
núcleo do inconsciente consiste em agências representantes de pulsão que querem descarregar seu investimento, ou seja, em moções de desejo. A descarga do sistema inconsciente passa para a inervação corporal para o desenvolvimento do afeto, mas esta via também é disputada pelo pré-consciente.

O ego e suas relações objetais, seria o elemento que permite pensar passagem entre princípio de prazer e princípio de realidade, pois sua constituição determina a diferenciação pessoa-mundo, adiamento da satisfação e domínio dos estímulos pulsionais. 0 ego (que tem sua medida inconsciente) é um suporte constante da energia libidinal que não se origina nele, mas o toma como estação intermediária do percurso na libido - a libido é capaz de realizar fluxos e refluxos em direção relação ao mundo exterior. Pelo princípio de constância, ou quando este investimento atinge um certo nível é necessário descarregálo para evitar a produção do desprazer - nesse momento o ego envia parte da libido para os objetos tornando-se libido do ego e libido objetal.

O ego com função de suporte das pulsões de autoconservação, pode ser "ego de prazer" que apenas deseja e trabalha para aquisição do prazer ou o "ego de realidade" que tende ao útil, ou seja, assegura-se contra todos os danos possíveis. Ambos são modalidades de operação da pulsão de autoconservação, segundo estejam sob o signo do princípio do prazer ou do princípio de realidade (Freud, 1911). Ego da realidade é responsável pelo discernimento, juízo entre o verdadeiro e o falso pela prova da realidade, sujeito as exigências da vida e o ego do prazer se vê submetido a ele. Antes o 'ego de realidade' se contrapunha ao 'ego de prazer' pelas diferenças na pulsão de auto-conservação, mas, com a introdução do conceito de narcisismo (1914), se entende que, para reestabalecer a satisfação narcisista, o ego introjeta os objetos gratificantes do mundo exterior e projeta para ele tudo que é fonte de desprazer. Assim o 'ego de realidade' originalmente proposto torna-se um 'ego de prazer purificado', que preza acima de tudo a qualidade do prazer, e o 
'mundo exterior separado é considerado hostil'. Assim se justifica ego=prazer; realidade=neutralidade e desprazer. No momento que o narcisismo primário é invadido pelo objeto emerge a terceira antítese do amor: a oposição amor/ódio.

\section{III.4.1. Descobertas de Allan Shore}

Schore (1994), se destaca dentre os autores que têm se esforçado para serem “bilíngues” em psicanálise e neurociência, exatamente por trabalhar com ordem de causalidade que parte da experiência subjetiva para a materialidade subjacente: propõe um “modelo psiconeurobiológico de ontogênese da auto-regulação emocional”. Para Shore, a maturação da região órbito-frontal direita depende da experiência emocional primária, do ambiente emocional estabelecido pela díade bebê-mãe que estimula e contém aspectos emocionais da criança, permitindo seu desenvolvimento socioemocional e a progressiva capacidade para lidar com relações de objetos mais complexas. Nesse sentido, fundamenta neurobiologicamente a instauração do ego enquanto instância que encontra sua coesão (quanto às suas fronteiras internas e externas) devido à experiência de satisfação primária. Os objetos primários pulsionalizados servem de base para todos os processos de ligação e permitem a vigência do princípio de prazer e de realidade.

Nas neurociências, Allan N. Schore (1994) desenvolveu um modelo "psiconeurobiológico de ontogênese da auto-regulação emocional" associando neurodesenvolvimento `a teoria do desenvolvimento e da relação mãe-bebê na constituição do self. Shore investigou em profundidade a maturação do córtex órbito-frontal de hemisfério direito incluindo seus inputs e outputs, circuitarias que passam pelas estruturas do tronco cerebral e sistema límbico. 0 córtex órbito-frontal regula as estruturas subcorticais por um sistema inibitório (colinérgico), controlando o sistema autonômo (incluindo o sistema nervoso visceral), ou seja, controlando manifestações somáticas da 
emoção como respiração, sudorese, pressão arterial, etc. e, por outro lado, tem uma função importante na motivação, estimulação do sistema locomotor e na administração dos aspectos prazerosos da interação social, devido ao sistema dopaminérgico. Para Shore, a maturação desta região depende de um ambiente social primário, ou um cuidador primário (mãe) que estimule e contenha aspectos emocionais da criança, permitindo seu desenvolvimento socioemocional e a progressiva capacidade para lidar com relações de objetos mais complexas. Nesse sentido fundamenta neurobiologicamente a instauração do ego enquanto instância que encontra coesão (questão das fronteiras internas e externas do self ) devido à experiência de satisfação primária.

Segundo a leitura de Allan Shore dos conceitos Kleinianos de identificação projetiva, Freud descreveu como o inconsciente pode atuar como órgão receptivo enquanto Melanie Klein descreveu como este sistema atua como órgão transmissor e como estas transmissões atuam sobre outra mente inconsciente. Seu ponto de vista é o de que a ênfase de Klein recaiu sobre o desenvolvimento da fantasia ou das 'cognições inconscientes' geradas pela mente do bebê. Segundo seu ponto de vista, isto não está de acordo com as recentes descobertas no campo do desenvolvimento que demonstram que os estados do bebê são menos complexos cognitivamente e mais corporais e sensório-afetivos. Segundo sua pesquisa sobre 'regulação do afeto', os estados primitivos são psicobiológicos pouco mentais ou cognitivos e, portanto, devem ser abordados como estados primitivos corpomente. Os estados afetivos transitam na díade mãe-filho e este sistema eficiente dirigido somaticamente, comunicação emocional de rápida atuação é essencialmente não verbal. Segundo seu ponto de vista, novamente, a discussão se coloca na comunicação de estados e processos afetivos internos, e não em cognições e conteúdos. Segundo suas pesquisas, é necessário incluir na discussão sobre a neurobiologia do comportamento emocional a maturação em estados de desenvolvimento precoce do hemisfério direito, dominante 
durante os três primeiros anos de vida, e especializado em processamento de informações emocionais.

O hemisfério direito é profundamente conectado com o sistema límbico, e o sistema nervoso autonômico, portanto está envolvido no controle das funções vitais e com o manejo do estresse e de alterações emocionais. Tem um papel fundamental no acesso aos estímulos positivos e negativos, por um mecanismo similar ao princípio prazer-desprazer. (Shore, 2003, pg 61).

Um campo de pesquisa tem se desenvolvido sobre a comunicação emocional face-aface, predominantemente inconsciente, opera durante a infância. Segundo Shore, um tipo de comunicação de hemisfério direito a hemisfério direito se realiza entre a criança e a mãe. Este autor descreve a identificação projetiva como uma estratégia de relacionamento primitiva de regulagem da comunicação hemisfério-direito-a-hemisfério-direito, especialmente relacionado a estados afetivos intensos. Afirma que os afetos são fenômenos psicobiológicos e que o self se fundamenta no corpo, portanto a identificação projetiva representa uma comunicação não verbal mente-corpo. A identificação projetiva funcionaria como uma estratégia defensiva de regulação de afeto, sob condições de estresse interpessoal. Abuso e negligência do cuidador podem ocasionar severas desregulações dos sistemas psicobiológicos da criança recém-nascida, especialmente no incipiente hemisfério-direito, em desenvolvimento. A identificação projetiva funcionaria como uma estratégia dissociativa para lidar com traumas. Estes eventos são registrados na memória implícita de procedimento, inaugurando uma forma de funcionamento presente durante a vida adulta.

A mãe sintoniza seu hemisfério direito à saída do hemisfério direito da criança para receber e ressoar com as flutuações do estado interno da criança. Essa comunicação 
inconsciente permeada por identificações projetivas facilita a maturação experiênciadependente do hemisfério direito da criança.

No contexto clínico, a identificação projetiva embora aparentemente invisível, instantânea, endógena, é um processo bidirecional de transações afetivas recíprocas muito rápidas dentro de um campo intersubjetivo construído pelo paciente e pelo terapeuta. 0 hemisfério direito teria também um papel central nos estados corporais da identificação projetiva. 0 autor relaciona a 'ressonância intersubjetiva' com o conceito de empatia, definido como habilidade de refletir o afeto do outro e ser hábil em responder em resposta a ele (Easser, 1974).

\section{III.4.2. Transtorno Borderline de Personalidade}

A Classificação dos Transtornos Mentais e do Comportamento (CID10) situa o Transtorno Borderline de Personalidade como um subtipo do Transtorno de Personalidade Emocionalmente Instável. Este último se caracteriza por tendência marcante para agir impulsivamente e sem considerar as consequências, associado à instabilidade afetiva. A impulsividade prevalece no Transtorno de Personalidade Emocionalmente Instável descrita como uma incapacidade para planejar ou antecipar a conseqüência dos atos, associado à intolerância, pois quando os atos impulsivos são criticados pode haver acessos de raiva, "explosões comportamentais" e até violência. O Transtorno Borderline de Personalidade, por sua vez, tem várias características de instabilidade emocional. Além disso, ocorre perturbação da auto-imagem, de preferências internas, e possível confusão quanto à preferência sexual. Em geral, este quadro acompanha sentimentos crônicos de vazio e esforços excessivos para evitar abandono. 0 humor básico destes pacientes é disfórico, perturbado por períodos de raiva, pânico ou desespero, mas raramente aliviado por períodos de bem-estar ou satisfação. Freqüentemente expressam raiva intensa, ou têm 
dificuldade para controlar sua raiva, que aparece relacionada com medo de abandono acompanham sentimentos de ser mau, e emoções associadas, como vergonha ou culpa.

Otto Kernberg $(1975,1995)$ usa o termo borderline para referir-se a uma estrutura singular de personalidade que tem como característica principal regressão ao processo primário de pensamento e fraqueza das funções do ego como: diminuição da tolerância, diminuição do controle de impulsos, diminuição de canais sublimatórios desenvolvidos. Segundo este autor, outro aspecto inespecífico da fraqueza da função egóica seria a diferenciação reduzida entre self e imagens de objetos, devido a uma patologia nas relações de objeto internalizadas na qual, por uma frustração excessiva de necessidades instintuais primitivas, principalmente orais, o ego utiliza-se do mecanismo de clivagem (splitting) para separar introjeções e identificações de natureza libidinalmente determinadas (tudo bom) daquelas agressivamente determinadas (tudo mal). Isso determina um círculo vicioso de projeção e reintrojeção de imagens de self agressivamente determinadas.

Melanie Klein (1991) fez uma breve menção aos pacientes borderline e descreve como três aspectos psíquicos centrais o fato de: (a) estarem imobilizados entre as posições esquizoparanóide e depressiva, com uma defensividade complexa tanto contra a fragmentação da posição esquizoparanóide, quanto contra a culpa e responsabilidade da posição depressiva; (b) terem se desenvolvido no contexto de um excesso de pulsão de morte e inveja, mas terem desenvolvido algumas relações objetais estáveis, ainda que organizadas em torno da dominância das partes más do self sobre as partes boas; (c) terem uma estabilidade de personalidade frágil, pois avançaram a posição esquizoparanóide apenas devido ao desenvolvimento de um sistema rígido de defesas, conhecido originariamente como organização narcísica que depois se tornou um sistema delirante de defesa (como organização defensiva), e, mais recentemente, aparece como uma 
organização patológica com função não apenas defensiva, mas também como adesão rígida à certas relações objetais e fonte de prazer de tipo patológico, usualmente perverso.

Green (1990) insere o estudo dos pacientes borderline, denominados por ele como casos-limite entre as questões que a noção de "limite" recoloca à metapsicologia Freudiana, revista na sua riqueza original. Os casos-limite não se constituem a partir da psicose, e também não podem ser definidos dentro dos habituais campos de conflito das neuroses, como entre um núcleo histérico e um núcleo obsessivo. A especificidade da estrutura "limite" a circunscreve como "entidade" relativamente autônoma definida por uma “característica indeterminada”. No interior de uma estrutura globalizante subgrupos ou núcleos de tipo perverso, depressivo, toxicômano e/ou psicóticos lutam pra se apoderar da estrutura psíquica como um todo. Segundo Green, nos casos-limites não se trata apenas do problema dos limites do ego, mas também da desorganização dos limites no interior do aparelho psíquico.

É central na dinâmica borderline a presença de dois tipos básicos de angústia, a angústia da separação, ou pavor da perda da parte ou do todo, e a angústia de invasão vivida como ameaça à identidade. Neste sentido o problema é do ego em relação aos seus objetos, um objeto inacessível e sempre fora do alcance do investimento e um objeto que “morde" o território do ego, perseguindo-o dentro de seu próprio território. A angústia de separação atinge seu máximo quando o objeto está presente e a angústia de intrusão se manifesta mais fortemente quando o objeto não está presente. As clivagens de ego no borderline se deve às falhas básicas de constituição do objeto, "mau" porque frustrador e rejeitador. A dinâmica dos objetos maus tem uma força e especificidade nos pacientes borderline: os objetos maus são cindidos em partes apetitosas e excitantes e partes nocivas, repelentes, frustrantes. Não há representação de fato de um 'bom' objeto 
(acolhedor, nutridor, receptivo, caloroso, tolerante), mas o que fica no lugar deste bom inexistente é um objeto sedutor, excitante que de fato nunca propicia a calmaria.

No Brasil, Luís Claudio Figueiredo vem produzindo uma série de trabalhos sobre a clínica do paciente borderline. Apesar de concordar com Kernberg quanto ao aspecto estrutural da etiologia destes casos, Figueiredo não considera que haja uma problemática narcisista central, mas sim oscilações abruptas entre o pólo esquizóide e narcisista, aspecto que ele considera fundamental na dinâmica afetiva destes pacientes (Figueiredo, 2003). Outro aspecto que ele ressalta em seu trabalho é o mecanismo do uso de personalidades "falso self" nestes pacientes, teoricamente criado para "ocultar e proteger o self verdadeiro, o que quer que este possa ser" (Winnicott, 1990). Para se protegerem em sua precariedade, numa adesão submissa ao outro e num mimetismo incontrolável (por sugestionabilidade compulsiva) e/ou auto-esvaziamento, o paciente cria uma forma de manter-se em relação simbiótica, evitando a insegurança de um objeto que ameaça com o abandono ou com a intrusão. Também nesse sentido, indivíduos borderline têm uma dificuldade muito grande para construir e manter uma imagem de si e de seus objetos, nas flutuações que seriam naturais, de magnitude e valor. Para esses pacientes, ou os objetos aparecem e desaparecem, lembrados e esquecidos alternadamente, ou trocam subitamente de valor afetivo com tendência à absolutização na escala bom-mau.

Com a introdução do narcisismo o ego objeto libidinal, também está sujeito aos investimentos libidinais que dele emanam. Federn descreve a perda das fronteiras do ego por desinvestimento destas nos estados de despersonalização. Figueiredo se apóia nas idéias de fronteira do Eu de Federn para descrever o que ele vai chamar de eixo foradentro ou eixo grande-pequeno de oscilação dos pacientes borderline. As fronteiras internas do eu (ego) considerado como sujeito e objeto (Federn, por Figueiredo, 2000) dependem da sua constituição e sustentação do investimento pulsional: "A criação e o 
investimento libidinal das fronteiras do $\mathrm{Eu}$, elásticas, porosas, mas funcionais, será determinante, segundo Federn para a constituição simultânea das realidades. Isto quer dizer que, um senso de realidade externa supõe um senso de realidade interna (a realidade psíquica do $\mathrm{Eu}$ ) e ambas pressupõe uma barreira, um limite entre elas, limite investido pulsionalmente.

Christopher Bollas (2003) vai trabalhar mais intensamente na vertente deste objeto primário do paciente, devido ao pressuposto de que há um objeto primário não figurativo, ou seja, calcado menos no seu caráter especular do que no tumulto emocional que ocorre no self quando se o tem em mente. 0 sentimento de turbulência, portanto, seria o próprio objeto primário que determina um desejo borderline pautado na busca de um estado de tumulto. Considero que o objeto primário calcado no sentimento de turbulência mantém estes pacientes em um funcionamento mental primitivo, e calcado em um estado de gratificação alucinatória ao invés de um contato com a realidade que pressupõe um bom funcionamento do princípio de realidade. Uma forma de vida mental governada pelo princípio de prazer tende ao sofrimento, pois a realidade novamente retorna (pois a fome não foi de fato alimentada) e exige que a 'criança' entre em contato com uma fonte verdadeira de alimento, e se relacione de forma real com ela. Ou seja, considero que nestes pacientes uma colisão fatal com a realidade decorre da experiência calcada na satisfação alucinatória de desejo, que não encontra a via de satisfação na realidade, devido ao "não representado", constituição malograda do objeto primário.

Exames de RM comparando volumes cerebrais das pacientes borderlines do sexo feminino com grupo controle (Tebatz van Elst et al, 2003) apresentaram alterações de volume nas regiões límbicas como amígdala e hipocampo, além do córtex órbito-frontal esquerdo e cíngulo anterior direito. Segundo estes autores, o comportamento alterado de pacientes borderline estaria diretamente relacionado com as diferenças na interação 
neurofisiológica límbico-prefrontal demonstrada pela perda de volumes da amígdala, hipocampo, região órbito-frontal esquerda e cíngulo anterior direito. Os volumes hipocampais reduzidos e a patologia envolvendo o pré-frontal, especialmente o córtex órbito-frontal e suas conexões límbicas (hipocampo e amígdala em particular) levam à hipótese de uma correlação neuropatológica da hyperarousal-dyscontrol syndrom, observada nos pacientes borderlines. Estas alterações volumétricas presentes em um circuito neuroanátomo funcional específico e volume cerebral normal no restante do encéfalo seria um padrão que diferenciaria o Transtorno Borderline de Personalidade de outras condições neuropsiquiátricas (Tebatz van Elst et al, 2003). Estudo de neuroimagem funcional RMf (block design) com tarefa de reconhecimento de faces com expressão emocional negativa em pacientes borderline apresentou hiperatividade da amígdala quando comparado com o grupo controle (Donegan et al, 2003). Segundo os autores, distúrbios nas relações interpessoais e desregulação emocional são os aspectos fundamentais das desordens de personalidade borderline e a amígdala tem um papel central nisso, pois modula vigilância e geração de estados emocionais negativos, especialmente medo e ansiedade. Outra conclusão do estudo, baseada em dados comportamentais é o de que os pacientes tendem a identificar faces humanas de expressão neutra como sendo expressões ruins, e, portanto os autores consideram que estes pacientes projetam atributos negativos nas faces de Eckman (teste da psicologia cognitiva constituído por fotos de pessoas com expressões - feliz, triste, assustada, neutra). Ainda sem serem questionadas os pacientes tenderam a descrever sentimentos ruins nas faces com expressões neutras, num mecanismo descrito pelos autores como projetivo. Por outro lado, a dinâmica afetiva de hiperresponsividade emocional e de projeção de elementos ruins pode gerar reações de evitação ou agressivas, ou seja, a contratransferência pode ser hostil. 


\section{III.4.2. Autismo}

Os pacientes autistas, apesar de capazes de imitar, não se tornam sujeitos da ação, ou seja, não introjetam a ação como pertencente a um eu constituído. 0 encontro gradual com o objeto como 'outro' além do self (Cesarie, 2005) e a passagem do aderir ao outro para o ver o outro seria criado no cuidado materno repetido, por um objeto que modula o encontro, e seria um pré-requisito para a passagem da imitação para a introjeção ou da bidimensionalidade para a tridimensionalidade. Segundo a autora, o vinculo se estabelece devido à capacidade materna para estabalecer um ressonância interna profunda com sua criança num ritmo interno vital (no qual a respiração é um elemento importante) permite que se elabore um 'ego corporal'. De forma análoga, os olhos refletem o investimento, o desejo dos pais que encontra a necessidade vital da criança, de ser vista como um ser vivente. Quão horrível é para a criança olhar para o espelho e não ver nada! (Winnicott, 1971 in Cesarie, 2005). Uma mãe irresponsiva não permite que a criança veja a ele mesmo nos seus olhos, para imitar, aderir ou antecipar. Sua experiência é de não existir, ou de ser transparente, como se desaparecesse ou se dissolvesse. Não ser e não existir é a experiência fundamental da contratransferência no trabalho com crianças autistas.

\section{III.4. Empatia e Bem}

Caso a bondade preceda a empatia, defendo a idéia de Sócrates de que só conhece a bondade aquele que é bom. Aqueles que não possuem a bondade não seriam capazes de compreender ações altruístas. Porém, segundo Plotino, todos os seres amam o Bem, simplicidade absoluta, pois, desde seu nascimento, o Bem incutiu-lhes amor pelo Bem. Dessa forma, a empatia não estaria restrita a uma pequena parte dos homens, qualificados como bons, mas `aqueles que buscam o Bem. Plotino descreve a busca do intelecto, rapaz 
em plena saciedade, que quando atinge sua plenitude essencial, não carrega nada obscuro ou indefinido. 0 Bem ilumina-o imprimindo sobre ele sua forma, e assim o intelecto tornase pura radiância (Plotino, 2008). No escrito ao qual esta breve incursão se refere, não há distinção clara entre Belo absoluto, Bem absoluto e Deus. 0 intelecto, assim como toda a realidade aspira ao bem, e precisa olhar para ele a fim de ser quem ele é. "O intelecto jamais deixa de desejar e atingir o Bem, pois o resultado do regozijo conseguido com a proximidade do Bem, renova eternamente seu desejo por ele". (Plotino, 2008, p.180)

Plotino identifica o "Eu" com o nível intermediário racional discursivo e especificamente humano da alma. Certas vezes, porém, "não há definição fixa, de modo que cada homem tem seu "eu", que se identifica precisamente ao nível que cada um exercita e mantém ativo". (Idem, p.182) Na experiência mística, o intelecto abandona sua atividade intelectiva, seu estado comum desperto, e substitui esse "Eu" por um outro que o transcende; " trata-se agora de seu "eu" supra-intelectivo, que não pensa e apenas ama o Bem/Uno. Será esse "eu" somente o que permanecerá ativo "no momento sublime do unimesmamento com o Uno/Bem". (Idem, p.182) A alma, possui portanto, níveis supraconscientes (na união mística), conscientes (no exercício de sua capacidade racional discursiva) e infraconscientes (presidindo atividades corpóreas involuntárias).

No estado místico, alma que retorna para unimesmar-se ao Uno/Bem não sai de si, mas apenas modifica seu estado habitual de consciência, pois ele (Uno/Bem) não está fora de nada, está com todas as coisas, mesmo que elas não o saibam. Ao fugir para fora do Bem, e tendo destruído a si mesmas, como uma criança que em loucura não reconhece seu pai, porém aquele que conhece a si mesmo, sabe de onde veio. "Quem ainda não viu o Belo absoluto deve pretendê-lo como bem, mas quem o viu, esse o respeita pela beleza, se preenche de um assombro prazeroso, ama com verdadeiro amor e agudo desejo, ri-se dos outros amores e despreza o que julgava belo antes (...)”. (Idem, p.184) A matéria, "cadáver 
adornado" é substrato sobre o qual as determinações qualitativas e quantitativas flutuam e não é identificada ao mal absoluto, ela é apenas a causa do mal moral. Sua origem é um dos problemas da obra de Plotino. Parece não ser possível que ela tenha outra origem senão um princípio metafisicamente anterior `a ela, pois, senão o princípio fundamental do Bem não se manteria. "Assim, a matéria seria indiretamente um produto do Bem; diretamente ela seria produzida pela alma (...)" (Idem, p. 103) A matéria, porém, possui uma função na estrutura da realidade. "Como um reflexo não existe sem uma superfície refletora, o universo sensível não poderia existir sem a matéria. As formas intelectuais não se afastam do intelecto mas ali permanecem eternamente"(...) “A matéria não é o que existe realmente, ela permace não-ente, não podendo, portanto, receber o que realmente existe" (Idem, p.104). 


\section{Capítulo IV - Discussão}

A empatia, pode ser descrita como duas formas básicas de funcionamento, que nos remete `a sua origem léxica: sentir-com (Mitfühlung) e sentir-dentro (Einfühlung). Pautados nos autores mencionados neste trabalho, consideramos que a empatia pertence a duas qualidades de experiência: (1) contágio emocional ou ressonância de afeto pela qual o eu-outro perdem suas fronteiras definidas; que não acompanha a idéia do Outro (emoções primárias, comunicação inconsciente de afeto, identificação projetiva, compreensão originária do ser-no-mundo, comunhão afetiva) e, (2) identificação que decorre sa imagem e representações do outro por espelhamento e mimetismo. Nosso conceito integral, portanto, considera o psiquismo como um vazio enquadrante a ser preenchido pelo cuidado e bons objetos primordiais. A empatia decorre da pré-concepção (Bion) ou de uma abertura originária do ser, de caráter inato e filogenético, de responsabilidade para com o outro como outro-eu, que é, também, diferente. Dois processos psicológicos distintos, que por sua vez possuem uma materialidade, na forma de sistemas cerebrais, diversos. Em termos neuroanátomo-funcionais se identificam dois sistemas sobrepostos que tem seus epicentros no hemisfério direito sendo o primeiro epicentro o córtex órbito-frontal (relacionado ao sentimento de si-mesmo); e, o segundo, a área somatosensorial (formador da auto-imagem) e suas aferências-eferências, provindos de àreas motoras e de linguagem (área de Broca).

Buscamos desenvolver um conceito integral de empatia, baseados na consideração de que a empatia é um fenômeno complexo, que inclui diversos níveis de análise. Os neuroestudos partem do pressuposto que podemos encontrar verdades ônticas sob as quais se 
estruturam um saber sólido e indiscutível. A verdade está na resposta fornecida pela técnica, que permite que se veja o escondido, revela como 'na realidade' somos e como podemos atuar sobre o nosso organismo interno. A neuropsicanálise, por meio da teoria e da análise de pacientes que sofreram algum tipo de lesão cerebal, estabelece um diálogo entre estas realidades. Afirma que os afetos são fenômenos psicobiológicos e que o self se fundamenta no corpo (Shore), portanto a identificação projetiva representa uma comunicação não verbal mente-corpo. A identificação projetiva funcionaria como uma estratégia defensiva de regulação de afeto, sob condições de estresse interpessoal. Abuso e negligência do cuidador podem ocasionar severas desregulações dos sistemas psicobiológicos da criança recém-nascida, especialmente no incipiente hemisfério-direito, em desenvolvimento. A identificação projetiva funcionaria como uma estratégia dissociativa para lidar com traumas. Estes eventos são registrados na memória implícita de procedimento, inaugurando uma forma de funcionamento presente durante a vida adulta.

É possível identificar em comum na psicanálise e na neurociência a busca pelo conhecimento sobre o homem, e o exercício de conquista do que, sob discriminações diversas, podemos designar como 'real'. O conceito de afinidade, por exemplo, deve estar em algum manual de psicanálise, e descreve bem como a natureza alcança uma constante de equilíbrio ou unidade: afinidade na química, se refere `as relações eletivas entre corpos químicos, os "amores" e os "ódios" moleculares. Na linguagem moderna a afinidade foi substituída por 'atrativos', ou um tipo de preferência da natureza. Um sistema sede de reações químicas, quando entregue a si-mesmo, evolui para um estado de equilíbrio químico. 0 estado de equilíbrio químico é alcançado quando as reações diretas e inversas se compensam, e as concentrações não variam mais, havendo uma constante de equilíbrio ("lei de ação das massas"). A mesma relação de concentração corresponde, para um sistema isolado, ’a uniformidade de temperatura ou equilíbrio térmico. 
Neste nosso trabalho, estudos de neurociência sobre empatia e sobre o self descrito como imagem corporal ou como experiência do si-mesmo, apontam para dois epicentros de atividade no encéfalo, ambos de hemisfério direito, relacionados `a empatia: a área somatosensorial cinestésica denominada 'homúnculo de Penfield', e a região mesial frontal, ou córtex órbito-frontal. Estas duas regiões seriam epicentros de sistemas cerebrais distribuídos, envolvendo, respectivamente, a área parietal direita (relacionada à espacialidade) e áreas límbicas, paralímbicas e mesolímbicas relacionadas com funções viscerais, emoção e memória.

Estas duas formas de abordagem do si-mesmo podem ser consideradas como proeminentes dentro das diferentes escolas de psicanálise. A psicanálise francesa, por um lado, mais centrada no estádio do espelho na constituição do Eu, e a escola kleiniana, que concebe os mecanismos pré-verbais e as fantasias inconscientes como predominantes para a experiência e a constituição do si-mesmo.

Estudos sobre a região somatosensorial, relacionada a imagem corporal, parecem corroborar a idéia de que para apreensão do estado emocional do outro, eu sofro a influência da imagem e da situação por meio dos mecanismos similares do sujeito observado e que minha representação corporal interna tem papel fundamental, o mais importante, para nossa análise é o fato de que este fenômeno ocorra sem a apresentação visual. A partir de estudos sobre a constituição da imagem ou esquema corporal e sobre o contágio de emoções por meio de um espelhamento da atividade do observador e do receptor, se pretendeu discutir de que forma o mecanismo de identificação projetiva pode ser relacionado `a empatia.

De fato, podemos relacionar identificação com a definição do termo empatia em relação ao impacto 'estético', ou seja, de estesis, que depende de espacialidade e corporalidade. As teorias que versam sobre empatia, em termos gerais realmente, dão 
grande enfase ao olhar ou `a presença do outro percebido por mim por meio da visão, percepção em um campo pré-reflexivo ou, ainda, como dissemos, por meio de mecanismos implícitos de mimese. Não podemos deixar de nos referir `a fase inicial do desenvolvimento do ego, durante a qual seus instintos sexuais encontram satisfação auto-erótica, de narcisismo. A fase preliminar do instinto escopofílico, na qual o próprio corpo do sujeito é o objeto da escopofilia, deve ser descrita como uma fase de formação narcisista. 0 instinto escopofílico se desenvolve e divide em ativo, deixando o narcisismo para trás, ou passivo, que, pelo contrário, aferra-se ao objeto narcísico. Suas atividades são auto-eróticas, ou seja, seu objeto é insignificante em comparação com o órgão de prazer.

Entendemos que a identificação (Freud), necessita da presença do outro, mas depende especialmente de sua uma imagem, e está relacionada `a representação corporal inconsciente sexuada. Porém, quando os mecanismos introjetivos e projetivos que possibilitam uma identificação não tem relação com um objeto inteiro ou íntegro, mas ocorrem na forma de elementos perceptivos e mnêmicos dispersos, matriz primitiva de ideogramas, que compartilham qualidades com o objeto inanimado e com o objeto psíquico, tal como Bion define os elementos- $\beta$, podemos falar de identificação projetiva.

Esta está na ordem do contágio emocional, do controle do self e da ausência de uma imagem ordenadora, ou ausência de um objeto total. Caso haja um uso maciço da chamada "identificação projetiva" a integração da personalidade fica comprometida. A integração de dados de áreas sensoriais polimodais se deve ao córtex frontal, especialmente a região órbitofrontal. Esta região permite que as informações que foram sendo projetadas e atuadas ou negadas por meio da identificação projetiva, possam ser integradas, pelo sentido pessoal, enriquecendo a subjetividade do sujeito. Estudos com ratos, demonstram a necessidade do córtex prefrontal relacionado `as demandas do ambiente e da prole, pois após o nascimento da prole se amplia a espessura deste córtex, por meio da proliferação de 
dentritos. Esta lei pode ser compreendida como o aumento da capacidade de continência necessária para processar novas demandas emocionais provenientes da relação entre a mãe e a criança. 0 aumento da capacidade de continência que decorre da maternidade, portanto, se reflete em termos de plasticidade neuronal em áreas frontais.

Os pressupostos desenvolvidos por Gallese no estudo do sistema de neurôniosespelho, supõe um 'mecanismo implícito de imitação' como base da intersubjetividade. Estudos com RMF demonstram que o contágio de um estado emocional de um sujeito para o outro ocorre por meio da ativação do mesmo sistema neuropsicológico específico para aquela emoção, em ambos os sujeitos. Decorre a conclusão de que um mimetismo encarnado (embodied) implícito, de tipo visuo-motor, ou espelhamento da atividade de sistemas neuropsicológicos fundamentam a intersubjetividade.

Sobre isto, apesar deste sistema ter sido inicialmente descrito a partir da atividade de áreas cerebrais específicas, o que se pode apreender por meio de uma revisão de literatura é que este mecanismo ativa áreas modalmente específicas. Ou seja, a tarefa a ser elaborada mentalmente de tipo auditivo, visual ou cinestésico, ativa áreas corticais diferentes. Devemos então diferenciar dois tipos de eventos que ocorrem no cérebro do sujeito obervador e no observado, aos quais as pesquisas nesta área se referem de forma indiscriminada: (1) reconhecimento da ação intencional do outro baseado no mimetismo implícito, que se deve a um sistema particular ativado em ambos; (2) "espelhamento" da atividade de sistemas neuropsicológicos, que depem da modalidade da emoção (tirsteza, dor, nojo, alegria, etc). 0 "sistema espelho", portanto, seria mais claramente definido como "mecanismo espelho".

O reconhecimento do outro baseado no "mimetismo implícito" se apresenta claramente na identificação de faces, considerando ainda que lesões em córtex somatosensorial direito na área correspondente à face geram dificuldades de expressão e 
reconhecimento de expressões faciais emocionais. Essa identificação imediata que parece estar relacionada com o próprio repertório vivencial do Eu, pode ser relacionada com o conceito de visada da consciência intencional, consciência enquanto ato de unidade entre o perceber e o percebido, ou entre noesis, e noemas. A estrutura da consciência é intencionalidade, ou seja, toda consciência é "consciência de" e a consciência transcendental é puro ato, e surge como condição de possibilidade do conhecimento, e no seu ato de visar dá significações `as coisas. Porém, mais uma vez, nos aparece um problema do novo, ou seja, (1) daquilo para o qual não se tem repertório, ou representação. Além disso, a empatia como identificação, levanta o problema da (2) liberdade e (3) não resolve a "indução primitiva de emoção".

Sobre o primeiro problema, a psicanálise permite que se pense o psíquico em termos de lugar, e não necessariamente em termos de conteúdo. Mais produtivo também, na neurociência seria seguir a linha de trabalho que considera a consciência não como uma unidade hermética que possui janelas para o mundo por meio dos canais sensoriais, mas como nossa própria condição de existência que se altera com o mundo e depende da forma como nos situamos nele e o "sonhamos" - estudos sobre estados alterados de consciência podem demonstrar a tese relativista do funcionamento dos canais sensoriais e da localização de conteúdos. Sobre os elementos não processáveis pela consciência, inclui-se além do traumático na psicanálise uma ordem perceptiva implícita, que toca no problema da percepção restaurada empiricamente pelos sistemas perceptivos clássicos, quanto a percepção de conteúdos inconscientes.

Quanto ao lugar do psiquismo na psicanálise, um conceito bom é o de psiquismo enquadrante, que decorre da função constitutiva e estimulante do objeto "absolutamente necessário" que é então negado. Negado 'para fora' converte-se em objetos de atração e repulsão e 'para dentro' converte-se em estrutura psíquica enquadrante, ou vazio. Vazio 
funciona como base desejante e coloca a vida mental em eterno movimento de 'busca, apreensão, realização, etc.'. Green desenvolve argumentos, portanto, contra a presença de um núcleo central do sujeito e a favor de um núcleo central ausente e se contrapõe aos conceitos psicanalíticos que priorizam um núcleo interno, algumas vezes narcísicamente investido, ou com forte componente inato, outras vezes apenas lócus de pronunciados mecanismos de cisão, culpa e reparação unificadora. Ainda sobre a possibilidade ou não de receber conteúdos estranhos aos próprios, a idéia de inconsciente como campo de infinitude permite que tudo e qualquer coisa seja possível de ser permeado pelo sujeito. A questão é o que resta, ou, melhor, "de tudo fica um pouco..." Por fim, devemos lembrar que o lugar de formação das imagens, o campo psíquico, na psicanálise, na sua divisão entre consciente e inconsciente, tem a característica de ser o lugar do sonho. Inclui material inconsciente e se difere do lugar na qual uma cena é transposta para o interior por meio de similitude ou analogia implicita visual e motora. Chegamos então a algumas conclusões sobre ao que se refere nosso conceito de empatia. Primeiro: pressupomos um lugar do outro dentro de mim no qual a percepção que tenho dele se aproxima de uma alucinação, está remetido a um campo de infinitude, e se remete `a tentativa de preenchimento de um vazio intransponível.

Segundo, as formas de preenchimento deste vazio podem ser por um mecanismo de identificação com o mundo e com o outro nas suas representações (imagens, falas, sons, toques) ou ainda na forma de algo que primeiramente estimula, enfraquece, enfurece, alegra, ou emoções primárias que não relacionadas com um objeto total, apenas nos remetem a um estado afetivo, como quando estamos sob efeito da identificação projetiva. Sobre isso, Ferenczi nos ilumina com a seguinte elaboração teórica: traumas inscritos no corpo e que sofreram um recalque profundo devido ao grau de dor envolvido, podem apenas ser despertados no corpo, e pela transferência. Este é o campo da memória corporal 
ou do registro sensorial. Nos remete ’a noção de ego corporal em Freud, e `a todas as funções continentes. O outro, então, além de funcionar como uma estrutura vazia enquadrante, funcionaria como um continente de registros sensoriais doloridos, recalcados e, também prazerosos, ou do campo das emoções primárias.

Voltando `a questão do contágio de emoções, o conceito chave de compreensão da intersubjetividade pela escola Kleiniana de psicanálise é a “identificação projetiva" e de fantasia. Na identificação projetiva a relação com o outro na fantasia (ou "expressão mental de instintos", Hanna Segal, 1975, p.24) e na realidade se dá em um campo marcado pela sobreposição de experiências emocionais. Para Klein, o ego, a partir do nascimento é capaz de formar e, de fato, é impulsionado pelos instintos e pela ansiedade a formar - relações de objeto, na fantasia e na realidade. A formação da fantasia é uma função do ego, pressuposto com um grau de organização muito maior do que foi usualmente postulado por Freud. 0 uso do mecanismo de identificação projetiva normal permite que a intersubjetividade seja compreendida como o campo da formação da subjetividade. Por outro lado, como nos alerta Grotstein, como podemos escapar do irônico ponto de vista segundo o qual identificar que percebemos o outro entrando dentro dele pode resultar em substituir o outro pelo self ou o self pelo outro? A empatia, porém, não exige necessariamente que minha sensibilidade se assemelhe a do outro. A questão, bem desenvolvida pela psicanálise, é por meio de qual mecanismo eu, diferente do outro, compreendo fenômenos emocionais que não se dariam da mesma forma em mim. Como posso entrar em contato com a alteridade, ou ter uma experiência vicária. Esta habilidade pertence ao espaço psíquico entre Eu e o Outro, no qual elementos emocionais encontram repouso, antes de tornarem-se próprios.

Segundo a leitura de Allan Shore dos conceitos Kleinianos de identificação projetiva, Freud descreveu como o inconsciente pode atuar como órgão receptivo enquanto Melanie 
Klein descreveu como este sistema atua como órgão transmissor e como estas transmissões atuam sobre outra mente inconsciente. Segundo seu ponto de vista, recentes descobertas no campo do desenvolvimento demonstram que os estados do bebê são menos complexos cognitivamente e mais corporais e sensório-afetivos. Segundo sua pesquisa sobre 'regulação do afeto', os estados primitivos são psicobiológicos pouco mentais ou cognitivos e, portanto, devem ser abordados como estados primitivos corpo-mente. Os estados afetivos transitam na díade mãe-filho e este sistema eficiente dirigido somaticamente, comunicação emocional de rápida atuação é essencialmente não verbal. Segundo seu ponto de vista, novamente, a discussão se coloca na comunicação de estados e processos afetivos internos, e não em cognições e conteúdos. Segundo suas pesquisas, é necessário incluir na discussão sobre a neurobiologia do comportamento emocional a maturação em estados de desenvolvimento precoce do hemisfério direito, dominante durante os três primeiros anos de vida, e especializado em processamento de informações emocionais.

Porém, concordamos que a imitação possa ocorrer por meio de mecanismos cinestéticos, pela observação de movimentos do corpo, como podemos inferir em crianças e animais. Porém, resta entender o fenômeno definido como simpatia denominado de “contágio emocional” prévio, não decorrente do estabelecimento da troca de olhares, e então, a identificação projetiva e o papel do hemisfério direito, especialmente da área órbito-frontal, não pode ser ignorada.

De fato, a importância da imagem na constituição do Eu pode ser relacionada com o papel da área somatosensorial sobre sujeitos que perderam membros, como braço, e vivem ainda um Eu integrado pela memória da imagem somatosensorial cinestésica. Reportam sensações táteis vívidas do membro fantasma e lidam com uma ilusão óptica como se fosse a própria imagem do braço; quando vêem o experimentador tocar na imagem do braço 
contralateral ao espelho que simula um braço integral o paciente que antes sentia dores no membro fantasma deixa de senti-las. A informação visual de que o membro existe se contrapõe à informação proveniente da área somatossensorial de que ele não existe. Com isso o cérebro compara informações e decide pela somatosensorial, de que o membro de fato não existe, e, portanto não pode haver atividade (que gera dor) naquela região somatosensorial.

Dentre os argumentos que permite questionar a base da empatia apenas no sistema sensorial de visão, ou seja, que considera a imitação de ações motoras precursora da empatia, incluímos o que, na psicologia cognitiva, tem se denominado como 'processamento implícito'. Discussões sobre o funcionamento de sistemas sensoriais como a visão e o reconhecimento de faces em sujeitos que sofreram lesões cerebrais inicialmente documentado por Poppel, Held e Frost (vide Schacter, 1992). O fenômeno denominado "blindsight" foi posteriormente descrito por Weiskrantz em referência `a natureza paradoxa do comportamento visual exibido por certos pacientes com lesão no córtex visual primário. Estes pacientes aparentemente eram cegos e negavam verem o estímulo apresentado em certas partes do campo visual, mas quando questionados sobre a localização ou certos atributos do estímulo os pacientes exibiam visão, pois sua performance de adivinhação era muito boa, e muitas vezes perfeita. A questão mais intrigante em relação a estes pacientes é exatamente como eles respondiam acuradamente aos estímulos apresentados em um campo de visão cego e como estas percepções diferiam das experiências visuais conscientes. Quando questionados sobre como eles descreveram os atributos dos estímulos se não os estavam vendo, os pacientes afirmavam que estavam apenas adivinhando. Isso demonstra o papel de outras áreas no próprio reconhecimento de faces. 
Segundo a psicanálise, a imitação, no decorrer do desenvolvimento deve ser substituída pela identificação, ou seja, por um mecanismo interno que possibilita uma relação com o outro dentro de totalidades separadas, ou alteridades. A identificação não seria uma simples imitação, pois depende da assimilação, sempre parcial, de conteúdos. A formação de símbolos depende da habilidade para juntar objetos discriminando a semelhança e a diferença entre eles. Ainda seguindo a referência de Bion, o outro, enquanto “O”, ou, na referência kantiana, "coisa em si”, "coisa incognoscível” não pode, em hipótese alguma ser acessado pois não se sujeita ’as formas inseparáveis da sensibilidade e entendimento humanos.

Sobre o segundo problema da empatia referir-se a uma identificação concordante, seria o problema da liberdade. A liberdade, de fato, exige um nível de elaboração sobre o simesmo e sobre o outro, que pode não existir quando se está sob domínio de uma identificação de grupo e sob domínio da identificação projetiva. Em Kant, a liberdade é uma vivência, um sentimento estético-moral do supra-sensível, a transição de um prazer sensorial para um sentimento moral ou a doutrina da beleza e do sublime na natureza e na arte, cuja presença via razão prática é inegável. Sublime denominamos um objeto cuja representação faz nossa natureza sensível sentir os seus limites, entretanto, a nossa natureza racional, encontra sua superioridade e liberdade em face da sensibilidade.

Sabemos que, para Freud, o trabalho em geral, em especial a arte é resultado da sublimação, resposta ideal da libido diante da necessidade do recalque. As forças libidinais especialmente a pulsão genital encontra uma expressão que não entra em choque com as exigências do superego, e ainda mantém o ego em sintonia com o ego Ideal, imagem interna projetada pelo próprio superego. 0 comportamento sublimado estabelece uma situação de equilíbrio entre as exigências libidinais internas e as da realidade externa. 
Retomando, a importância do tema da empatia nas teorias psicanalíticas atuais, que visam a clínica da 'continência', se refere `a criação (surgimento) e manutenção de um espaço de 'elaboração' do psiquismo, situado entre a realidade e a fantasia inconsciente, como o espaço transicional winnicottiano, ou a alucinose (Bion, 2004), pela qual um evento mental é transformado em uma impressão sensorial, e que se torna demonstrável em sua plena riqueza e profundidade no "ato de fé", atitude do analista e sua capacidade continente, e de reverie.

A melhor definição de empatia, é apenas "pré-concepção", ou um estado de expectativa que pode ou não realizar-se, transformando-se em concepção. Este estado de expectativa, ou sensibilidade, pode ser definido segundo Levinas, como, vulnerabilidade, responsabilidade, proximidade, contato, capacidade de ser tocado pelo outro, exposição ao outro. Também pode ser definido como "obsessão por um outro que não se manifesta", em vez de "ato intelectual de apreensão".

\section{IV.1. Sobre o Self}

O senso inato de self pode ser inferido pela capacidade de perceber a si mesmo separado do outro identificada em recém-nascidos. Bebês têm capacidade inata para discriminar entre estimulação externa e auto estimulação, pois identificam quando eram seus dedos que randomicamente tocavam suas bochechas ou quando era um toque externo. Os bebês apresentaram de forma significativa mais respostas de rotação de cabeça com lábios abertos em busca da mamada quando a estimulação era feita pelo experimentador, comparada com a deles próprios. Segundo meu ponto de vista, a idéia de self verdadeiro 'idioma da personalidade' formulada por Winnicott esclarece. 0 self verdadeiro seria o potencial herdado em contínua experiência do ser, adquirindo, de sua própria maneira e ritmo, uma realidade psíquica e um esquema corporal pessoais. Caso o 
ambiente permita ou facilite, uma certa 'tendência natural' busca integrar-se em grau crescente de complexidade. Nesse sentido, o encontro entre analista e terapeuta depende do desenvolvimento do 'idioma da personalidade' do próprio analista, e, nesse sentido, Bollas afirma que "o uso (que o paciente faz) do self verdadeiro de um analista, é a força do idioma (do paciente) descobrindo-se por meio das experiências de objeto" (Bollas, 1992, p. 28). 0 uso que se faz dos pais seria no sentido de buscar o próprio idioma, e nos primeiros anos de vida da criança, uma mãe suficientemente boa facilita o 'natural humano', ou seja, o fortalecimento do self verdadeiro do bebê e sua inserção no mundo de relações, e, dessa forma, a criança sente a busca do objeto como útil e gratificadora. Ainda segundo Bollas, com o conceito de self verdadeiro, Winnicott deu nome a um aspecto da vida psíquica que não tinha sido ainda teorizado. 0 crescimento da capacidade para pensar, segundo Bion, provém da possibilidade para representar uma nova experiência emocional por um sistema dedutivo-científico que derivou de uma experiência emocional anterior. A psicanálise, portanto, está sujeita ao mesmo processo no decorrer do seu desenvolvimento, e como sabemos, a experiência emocional é seu fundamento de pesquisa.

Para Allan Shore, a mãe sintoniza seu hemisfério direito à saída do hemisfério direito da criança para receber e ressoar com as flutuações do estado interno da criança. Essa comunicação inconsciente permeada por identificações projetivas facilita a maturação experiência-dependente do hemisfério direito da criança. No contexto clínico, a identificação projetiva embora aparentemente invisível, instantânea, endógena, é um processo bidirecional de transações afetivas recíprocas muito rápidas dentro de um campo intersubjetivo construído pelo paciente e pelo terapeuta. A leitura de Allan Shore dos conceitos Kleinianos de identificação projetiva, está de acordo com esta hipótese. Para ele, Freud descreveu como o inconsciente pode atuar como órgão receptivo enquanto Melanie Klein descreveu como este sistema atua como órgão transmissor e como estas 
transmissões atuam sobre outra mente inconsciente. Seu ponto de vista é o de que a ênfase de Klein recaiu sobre o desenvolvimento da fantasia ou das 'cognições inconscientes' geradas pela mente do bebê. Segundo seu ponto de vista, isto não está de acordo com as recentes descobertas no campo do desenvolvimento que demonstram que os estados do bebê são menos complexos cognitivamente e mais corporais e sensório-afetivos. Segundo sua pesquisa sobre 'regulação do afeto', os estados primitivos são psicobiológicos pouco mentais ou cognitivos e, portanto, devem ser abordados como estados primitivos corpomente. Os estados afetivos transitam na díade mãe-filho e este sistema eficiente dirigido somaticamente, comunicação emocional de rápida atuação é essencialmente não verbal. Segundo seu ponto de vista, novamente, a discussão se coloca na comunicação de estados e processos afetivos internos, e não em cognições e conteúdos. Segundo suas pesquisas, é necessário incluir na discussão sobre a neurobiologia do comportamento emocional a maturação em estados de desenvolvimento precoce do hemisfério direito, dominante durante os três primeiros anos de vida, e especializado em processamento de informações emocionais. Por outro lado, o papel da imitação é secundário, como atestam o fato de que os pacientes autistas, apesar de capazes de imitar, não se tornam sujeitos da ação, ou seja, não introjetam a ação como pertencente a um eu constituído. Os pacientes autistas, apesar de capazes de imitar, não se tornam sujeitos da ação, ou seja, não introjetam a ação como pertencente a um eu constituído. 0 encontro gradual com o objeto como 'outro' além do self (Cesarie, 2004) e a passagem do aderir ao outro para o ver o outro seria criado no cuidado materno repetido, por um objeto que modula o encontro, e seria um pré-requisito para a passagem da imitação para a introjeção ou da bidimensionalidade para a tridimensionalidade. Segundo a autora, o vínculo se estabelece devido à capacidade materna para estabelecer um ressonância interna profunda com sua criança num ritmo 
interno vital (no qual a respiração é um elemento importante) permite que se elabore um 'ego corporal'.

De forma análoga, os olhos refletem o investimento, o desejo dos pais que encontra a necessidade vital da criança, de ser vista como um ser vivente. Quão horrível é para a criança olhar para o espelho e não ver nada! (Winnicott, 1971). Uma mãe irresponsiva não permite que a criança veja a ele mesmo nos seus olhos, para imitar, aderir ou antecipar. Sua experiência é de não existir, ou de ser transparente, como se desaparecesse ou se dissolvesse. Não ser e não existir é a experiência fundamental da contratransferência no trabalho com crianças autistas.

Sua atividade apenas considera a falha na possibilidade de se constituir totalidades a partir de experiências vividas que provocam excesso pulsional e constituem o campo do traumático. Estas falhas, segundo meu ponto de vista, podem ser relacionadas com a maturação do sistema nervoso central e do corpo, ou seja, representações que não encontram lugar no corpo tendem a gerar ruídos, falta de discriminação, e a experiência é contaminada pelos excessos, nesse sentido, a experiência do real, enquanto possibilidade de articulação entre mundo interno e mundo externo, fica fragilizada. Num certo sentido, podemos pensar em diversos conceitos, mas a base sobre a qual o desenvolvimento da personalidade ocorre, podemos situar no todo.

De qualquer forma, sugiro que o centro de processamento emocional, ou centro a partir do qual o Eu se relaciona com o outro, situado no córtex frontal dorsolateral permite o que as experiências que estão dispersas em áreas terciárias do córtex sejam assimiladas e tornem-se parte da própria experiência. De fato, este dado pode ser relacionado com o fato de que, durante a posição depressiva mecanismos projetivos e introjetivos atuam, de forma a possibilitar um campo de interação entre conteúdos. A idéia de um 'campo potencial' criada por Winnicott, ou ainda a relação entre continente e conteúdo descrita por Bion 
seriam conceitos que permitem desenvolver a idéia das comunicações inconscientes. A teoria de objetos implica em um uso pessoal e de objetos que caem neste campo intersubjetivo, vários tipos de provocações podem gerar um objeto interno. Objetos internos, aonde meus objetos se tornam os do outro e os do outro meus. Este campo intersubjetivo é necessário para a apreensão do estado de mente do outro.

O encontro gradual com o objeto como 'outro' além do self (Cesarie, 2004) e a passagem do aderir ao outro para o ver o outro seria criado no cuidado materno repetido, por um objeto que modula o encontro, e seria um pré-requisito para a passagem da imitação para a introjeção ou da bidimensionalidade para a tridimensionalidade. Segundo a autora, o vinculo se estabelece devido à capacidade materna para estabalecer um ressonância interna profunda com sua criança num ritmo interno vital (no qual a respiração é um elemento importante) permite que se elabore um 'ego corporal'. Neste trabalho revisaremos uma vasta bibliografia de estudos de neuroimagem, com o objetivo de apresentar as diferenças entre teoria da mente e empatia, inferida por resultados de ativação cerebral.

A enfase de psicanálise nos processo identificatórios na constituição do Eu, sua enfase nas imagos (paterna e materna - ou a fusão delas "imago parental") beira a afirmação constitucional do Mesmo. O Mesmo no qual tudo é igual, “O mundo contemporâneo, científico, técnico e gozador se vê sem saída (...) não porque tudo lhe é permitido e, pela técnica, tudo possível, mas porque nele tudo é igual. 0 desconhecido logo faz-se familiar e o novo, costumeiro." (Levinas, 2009, p.31) Curioso também é a psicanálise ser fundada por uma "técnica", da transferência.

Portanto, a solução, de Winnicott na qual a "mãe suficientemente boa" instaura a apropriação do "gesto espontâneo", colocando a ênfase no "ambiente" (psicoemocional) ao invés da ênfase no mundo pulsional hereditário, ainda carece da definição do "desejável". 
Não funda uma Ética, apesar do conceito de "espontâneo" sugerir uma Ética fundada no estético. E de fato, se encontra em psicanálise a referência `a personalidade como estilo, ou o aparelho psíquico apenas como um grande ordenador e produtor de imagens, produto do “olho da mente” reversão de perspectiva monocular para a visão binocular (Bion).

A mãe, se imersa no Mesmo por uma desapropriação de si no indiferenciado compartilhado, permite apenas o estímulo para que o gesto seja espontâneo dentro de limites impostos por seu próprio ideal. A identificação projetiva é o auge da mesmidade. 0 outro que me invade tomando qualquer possibilidade minha de ser o Outro, ou seja, descolar-me do Mesmo, como imprópria.

Porém, o falso self presente nos desvios de personalidade como sociopatias acompanham, em graus diversos, um sentimento 'de não sentir' prazer ou dor, acompanhado de um falso sentimento de vitalidade. 0 verdadeiro self, além de suas características estéticas, se fundamenta em processos constitutivos mais profundos, relacionados `a satisfação e `a constituição de bons objetos. Com quem, afinal, posso dialogar. Dialogar implica um Outro, como imposição Ética da alteridade e primeiro, em uma relação de assimetria fundamental. A psicanálise descreve a necessidade de um "caldo indiferenciado" do Eu para maturar áreas cerebrais que me "conectam" com o outro, tanto por meio de uma imagem especular, quanto por meio de uma ressonância afetiva. Porém, a integração, ou a unidade do Eu só se torna possível caso haja a predominância de bons sentimentos e o reconhecimento de uma alteridade prévia. Aderir ao mesmo mas "desassimilar-se" ou "destornar-se assemelhado dele".

“A relação do instinto com exterioridade não é um saber, mas uma morte”, diria Levinas. Então, a "nova psicanálise", coloca o verdadeiro outro em um inatingível ponto do transcendental (além da imanência), como na afirmação: “o Outro é transcendência”. Uma análise mais cuidadosa assemelha esta idéia `a idéia de "coisa em si”. Situados no 
pensamento de Levinas, entendemos que esse transcendental, é o "pensante", o ser que existe em relação `a uma totalidade mas permanece separado dela, permanece Eu.

Levinas responde `a isso, partindo da questão: “Como se realiza (...) a simultaneidade de uma posicão de totalidade e de uma reserva a seu respeito ou separação?” Cito Levinas: “Que significa a relação com uma exterioridade que permanece não assumida nesta relacão? Tal é o problema do eu e da totalidade, que coloco. É o próprio problema da inocência (...) Para que a exterioridade possa apresentar-se a mim é preciso que, enquanto exterioridade, ela ultrapasse os termos da consciência vital, mas que, ao mesmo tempo, enquato presente, não seja mortal `a consciência”. (Levinas, 2009, p. 37) Por fim, ele afirma que o milagre tem um estatuto ontológico entre o vivido e o pensamento: “Esta penetração de um sistema total em um sistema parcial, que não o pode assimilar é o milagre. A possibilidade de um pensamento é a consciência do milagre ou a admiração". (Idem, Ibid.) 0 milagre rompe a consciência biológica, ele é o começo da experiência, e, por ele, o pensamento não é simplesmente reminiscência, mas sempre conhecimento do novo. Esta é a fonte ética de Levinas, o milagre antes da luz, o milagre antes da razão.

Contra o império egocêntrico do Mesmo, se direciona o Eu para um Outro que marca uma heterogeneidade, a relação com o rosto não é conhecimento de objeto. A visão, no seu sentido primário, não deixa de ser contato e proximidade, carícia do "visível" e do "audível”, "exposição ao ser" - que se efetuam à distância. À palavra do Outro o sujeito pode recusar-se a responder, oferecendo o silêncio ou a violência. Mas, assim, o sujeito nega a si próprio como sujeito, já que só é Eu como resposta a um Tu, enquanto responsabilidade perante e por um Tu. Consideramos que Levinas demonstra a finalidade do projeto de Deus aos homens, que é abdicar da materialidade de seu corpo físico pela experiência transcendental na qual não sou mais levada pelo meu ego, mas pelo divino em mim. A experiência do sublime advém de Deus, pelo Outro. É possível ver Deus na complexidade da 
experiência com o Outro ou ver apenas a matéria que responde a estímulos impregnados de força material.

A transcendência do rosto é, ao mesmo tempo, a sua ausência do mundo a sua condição de estrangeiro. A fé não é o conhecimento de uma verdade suscetível de dúvida ou de certeza; for a destas modalidades, ela é o face-a-face com um interlocutor substancial - origem de si, que já domina os poderes que o constituem e o agitam, um tu, surgindo inevitavelmente, sólido ou numenal, atrás do homem conhecido neste pedaço de pele absolutamente decente que é o rosto (...)" (Levinas, 2009, p.58) A dimensão do divino abrese através do rosto humano - sua proximidade é no ser um momento da revelação. Ouvir a palavra divina não equivale a conhecer um objeto, mas a estar-com uma substância que ultrapassa sua idéia em mim. Outrem é o próprio lugar da verdade metafísica e indispensável `a minha relação com Deus. A metafísica tem lugar nas relações éticas, compete `as relações inter-humanas o papel que Kant atribuía `a experiência sensível no domínio do entendimento.

É pela maneira como o ser está aí que aparece a ética do ser, toda a proximidade pressupõe sempre, de uma forma ou outra, a proximidade do Próximo, a "humanidade". Próximo é o que permite que o Eu seja Eu.

\section{IV.2. Política e o desejável}

Levinas tece críticas `a psicanálise na qual não há liberdade, segundo sua ideologia subjacente que descobre as fórmulas de um ser sem traços humanos, mas apenas "máquinas-desejantes". Desejo, ambíguo pois se deixa compreender, apesar de mover-se determinado pelo instinto mecânico, que confere "espontaneidade" a um sujeito ilusório. A pulsão, na aparência de um fim, se faz passar por valor que, consequentemente, ordenado em razão prática, é promovido a um princípio universal. Ele afirma, citando Espinosa (o 
grande demolidor das ideologias), que: “é o desejável que está em valor, não é o valor que suscita desejos" (Levinas, 2008, p.23).

Do nosso ponto de vista, a defesa da empatia considera a importância da alteridade e da liberdade de pensamento. Segundo Espinosa, o estado de Natureza por ser física dos corpos e lógica dos afetos é pura relação de força. "Enquanto o direito natural humano (parte do estado de Natureza), for determinado somente pela potência de cada um, será nulo" (Chauí, 2003, p. 163). A marca do estado de Natureza é sua impossibilidade de gerar o esforço de conservação no ser, enquanto força mais potente e contrária ao direito natural isolado, desencadeando a lógica das afecções e dos afetos. No estado de Natureza não há justiça, pois os mais fortes subjugam os mais fracos. Nesse estado "é possível distinguir duas modalidades da potência natural humana: a que é senhora de si, sui juris, porque age e existe segundo seu ingenium e repele a força com a força, vingando-se da violência; e a que está alterius juris ou sob a potência mais forte de outrem, quando alguém lhe domina o corpo (prendeu-lhe e tirou-lhe meios de defesa), seja porque lhe domina o ânimo, mediante o medo de castigos ou a esperança de benefícios, fazendo com que se submeta a ponto de considerar como desejo seu a satisfação do desejo desse outro a quem serve" (Idem, p.161).

Consideramos que a psicanálise deveria apresentar mais claramente suas conexões com a política. Espinosa, na sua defesa pela democracia como o mais natural dos regimes políticos e cronologicamente o primeiro, apresenta uma noção de pacto como um acordo mútuo no qual o estado de Natureza é superado por um indivíduo coletivo, corpo político, cujo direito natural é o direito civil. A liberdade, para Espinosa (Chaui, 2003) atinge seu máximo no exercício pleno da razão, diferente de uma concepção de livre-arbítrio onde prevalece a escolha contingente, entre alternativas possíveis. Sua liberdade está no exercício pleno da razão e o agir segundo a necessidade de sua natureza. É, portanto, por meio da ação sob direção da razão que e pelo fortalecimento do que os homens 
compartilham naturalmente que reside o aumento da vida e da liberdade de cada um. A vitória do 'direito natural' (potência natural de existir e de agir que se extende até onde puder exercer-se) provém do aumento da potência individual, quando suas paixões não faz os homens contrários entre si, mas sim, determinados pela lógica das noções comuns, estabelecem concordância pela conveniência entre as partes de um mesmo todo. No pacto cada indivíduo concorda em que o direito natural de cada um a todas as coisas seja exercido coletivamente e não mais seja determinado pela apetite de cada um, mas sim pela potência de todos em conjunto. O que sustenta esta transferência de direito é a verdade eterna de que "os homens não abandonam um bem senão por esperança de um bem maior e que, entre dois bens sempre escolhem o que julgam o maior e, entre dois males, o que julgam o menor" (Chaui, 2003 p. 166). "Porém o que se transfere são os direitos, desde que não implique em perda de liberdade de pensamento e de palavra" (Idem, p.166). 


\section{Referências}

Adolphs R (2002). Neural systems for recognizing emotion. Curr. Opin. Neurobiol. 12: $169-177$.

Adolphs R, Damásio H, Tranel D, Cooper G, Damásio AR (2000). A role for somatosensory cortices in the visual recognition of emotions as revealed by threedimensional lesion mapping. The Journal of Neuroscience 20: 2683-2690.

Aguiar DV (2006). Espaço, corpo e movimento: notas sobre a pesquisa da espacialidade na arquitetura 74 Arq. Texto 8.

Amaro Jr E, Simone AD, Cesário AC (2007). Studying auditory emotional experience and mirror neurons by simultaneous and interactive FMRI sessions. Trabalho apresentado em Proceedings, ISMRM 15 th Annual Meeting, Salvador, BA.

Armel KC e Ramachandran VS (2003). Projecting sensations to external objects: evidence from skin conductance response, Proc. R. Soc. Lond. B, p.1499-1506.

Baron-Cohen S (2001). Theory of mind and autism: a review. Special issue of the international review of mental retardation 23:169.

Baron-Cohen S, Campbell R, Karmiloff-Smith A, Grant J, Walker J (1995). Are children with autism blind to the mentalistic significance of the eyes/ British Journal of Developmental Psychology 13:379-398.

Baron-Cohen S, Leslie AM, Frith U (1985). Does the autistic child have a 'theory of mind'? Cognition 21:37-46.

Berlucchi G, Aglioti S (1997). The body in the brain: neural bases of corporal awareness. TINS 20 (12): 560-564.

Bíblia (1995). Edições Loyola. São Paulo, Brasil: Paulinas.

Bion WR (1994). Estudos psicanalíticos revisados - Second thoughts / W. R. Bion; tradução de Wellington M. de Melo Dantas. 3aㅗ ed. revisada - Rio de Janeiro: Imago.

Bion (1997). Ressonâncias / organizadora Maria Olympia de AF /França; coordenação Sociedade Brasileira de Psicanálise de São Paulo, São Paulo: Imprensa Oficial do Estado.

Bion WR (2004a). Transformações: Do aprendizado ao crescimento / WR Bion; tradução Paulo César Sandler. 2ª ed. - Rio de Janeiro: Imago. 
Bion WR (2004b). Elementos de psicanálise / tradução original de Jayme Salomão; revista por Ester Hadassa Sandler e Paulo César Sandler. - 2ª Ed. - Rio de janeiro: Imago.

Blumer (1975). D Temporal lobe epilepsy and its psychiatric significance. DF Benson \& D Blumer eds., Psychiatric aspects of neurological disease. New York: Grune \& Stratton.

Bollas C (1992). Forças do destino - Psicanálise e idioma humano. Rio de Janeiro: Imago.

Bollas C (2006). Perceptive identification. Psychoanalytic Review 93(5): 713-717.

By Greif, Esther B, Hogan, Robert (1973). The theory andmeasurement of empathy. Journal of Counseling Psychology. Vol 20(3), 280-284.

Cacciola MLO (1994). Shopenhauer e a questão do dogmatismo. São Paulo: Editora da Universidade de São Paulo.

Cannon WB (1939). The wisdom of the body. 2nd Ed. New York:W.W.Simon (First edition, 1932).

Calligaris C (1989). Uma introdução à uma clínica diferencial das psicoses. Porto Alegre: Artes Médicas.

Canteras NS (2002). The medial hypothalamic defensive system: hodological organization and functional implications Pharmacology. Biochemistry and Behavior 71:481491.

Caper R (2002). Tendo mente própria: uma visão kleiniana do self e do objeto. Rio de Janeiro: Imago.

Capra F, Bohm D, Davies P, Lovelock J, Sheldrake R, Dossey L, Griffiths B (2000). El espíritu de la ciencia: Edición a cargo de David Lorimer. Barcelona, España: Kairós

Carr L, Iacoboni M, Dubeau MC, Mazziotta JC, Lenzi GL (2003). Neural mechanisms of empathy in humans: a relay from neural systems for imitation to limbic areas. Proc Natl Acad Sci 100:5497-5502.

Cesarie AOD (2005). Early trauma and narcissism-autism bipolarity Int J Psychoanal 86:657-75.

Chaui M (2003). Política em Espinosa. São Paulo: Companhia das Letras.

Cintra EMU (2004). Melaine Klein. Estilo e pensamento. São Paulo: Escuta.

Collins W (2004). Collins German Dictionary, complete \& unabridged, 5th Sons \& Co.

Ltd. HarperCollins Publishers. 
Damásio AR (1998). O erro de Descartes: emoção, razão e o cérebro humano. São Paulo: Ed. Schwarcz Ltda.

Darwin C (1920). The expression of the emotions in man and animals. New York: Appleton-Century.

Dosh M (2006). Mirror neuron activity in contagious yawning: a fMRI study.

Carr, L., Iacoboni, M., Dubeau, M.C., Mazziotta, J.C., Lenzi, G.L., 2003. Neural mechanisms of empathy in humans: a relay from neural systems for imitation to limbic areas. Proc. Natl. Acad. Sci. 100, 5497- 5502.

Chaminade T, Meltzoff NA, Decety J (2005). Neuropsychologia An fMRI study of imitation: action representation and body schema 43: 115-127

Devinsky $O$ (1984). Bear D Varieties of aggressive behavior in temporal lobe epilepsy. American Journal of Psychiatry 141: 561-656.

Diamond D (2004). Attachment Disorganization The Reunion of Attachment Theory and Psychoanalysis Psychoanalytic Psychology Copyright, by the Educational Publishing Foundation, Vol. 21, No. 2, 276-299.

Dias EO (2003). A teoria do amadurecimento de DW Winnicott. Rio de Janeiro: Imago.

Dilthey W (2001). Empathy and Verstehen. A Contemporary Reappraisal. Austin Harrington. European Journal of Social Theory 4(3): 311-329.

Dilthey W (2008). Idéias acerca de uma Psicologia Descritiva e Analítica. Tradução: Artur Morão Colecção: Textos Clássicos de Filosofia - Direção: José M. S. Rosa \& Artur Morão Universidade da Beira Interior, Covilhã.

Donegam N (2003). Amygdala Hyperreactivity in Borderline Personality Disorder: Implications for Emotional Dysregulation. Biol Psychiatry, 54:1284-1293.

Dosh M (2006). Mirror neuron activity in contagious yawning: a fMRI study revista?

Etlin, Richard (1998). Aesthetics and the spatial sense of self, The Journal of Aesthetics and Art Criticism, 5:1-19.

Feenberg A (1999). Questioning Technology. New York: Basic Books.

Ferenczi S (1991). Psicanálise I. São Paulo: Martins Fontes. (1990) Psicanálise III, São Paulo: Martins Fontes.

Ferrari PF, Kohler E, Fogassi L, Gallese V (2000). The ability to follow eye gaze and its emergence during development in macaque monkeys. PNAS; 97(25):13997-14002.

Figueiredo LC (1989). Matrizes do pensamento psicológico. Petrópolis, RJ: Vozes (1996) Revisitando as psicologias - da epistemologia à ética das práticas e discursos psicológicos/ Edição revista e ampliada. - São Paulo: Educ; Petrópolis, RJ: Vozes. 
(2001) Psicanálise e Universidade. Psicol. USP, vol12(2):pg xx.

(2003)Psicanálise: Elementos para clínica contemporânea. São Paulo:

Escuta.

Fogassi L, Gallese V (2001). Neurophysiological mechanisms underlying the understanding and imitation of action. Nature Neuroscience Reviews 2:661-670.

Fontanari J (2008). Mito e Psicanálise: quando eles nos vivem e quando nós os vivemos? Contemporânea - Psicanálise e Transdisciplinaridade, 05 Disponível em: www.contemporaneo.org.br/contemporanea.php

Fossati P (2003). In Search of the Emotional Self: An fMRI Study Using Positive and Negative Emotional Words Am J Psychiatr 160:1938-1945

Freud S (1969). ESB, Rio de Janeiro: Imago.

(1900) A interpretação dos sonhos In: Op. Cit. vol. V, capVII, pg. 543-665.

(1910) Um tipo especial de escolha de objeto feita pelos homens contribuições à psicologia do amor I. In: Op. Cit. vol. XI, pg.149-157.

(1911) Formulações sobre os dois princípios do funcionamento mental In: Op.

Cit. vol. XII, p. 271-286.

(1913) Totem e tabu In: Op. Cit. vol.XIII, p.13-193.

(1914) Sobre o Narcisismo: uma introdução In: Op. Cit. vol. XIV, p. 83-125.

(1915) 0 inconsciente In: Cit. vol. XIV, p. 183-239.

(1920) Além do princípio de prazer In: Op. Cit. vol. XVIII, p. 13-85.

(1926) Questão da análise leiga - conversações com uma pessoa imparcial In: Op. Cit. vol. XX, p. 204-293.

(1940) A divisão do ego no processo de defesa In: Op. Cit. Vol. XXIII, p. 307-32.

Freud S (2004). Escritos sobre a psicologia do inconsciente, volume I: 1911-1915/ coordenação geral da tradução Luiz Alberto Hanns - Rio de Janeiro: Imago.

(1911) Formulações sobre dois princípios do acontecer psíquico, p. 63-77.

Freud S (2007). Escritos sobre a psicologia do inconsciente, volume III: 1923-1938/ coordenação geral da tradução Luiz Alberto Hanns - Rio de Janeiro: Imago.

(1921) Psicologia de grupo e análise do ego, p. 91-169.

(1923) O Eu e o Id, p. 13-68.

Freud S (1895). Projeto de uma psicologia In: Gabbi OF. Notas a projeto de uma psicologia: as origens utilitaristas da psicanálise. Rio de Janeiro: Imago (2003). 
Gallese V, Fadiga L, Fogassi L, Rizollatti G (1996). Action recognition in the premotor cortex. Brain 119:593-609.

Gallese V (2003). The roots of empathy: the shared manifold hypothesis and the neural basis of intersubjectivity. Psychopathology 36(4):171-180.

Dai neuroni specchio alla consonanza intenzionale: Meccanismi neurofisiologici dell'intersoggettività.

Garcia TJ Edith Stein e a formação da pessoa humana

Green A (1990). Conferências Brasileiras - metapsicologia dos limites. Rio de Janeiro: Imago

(1999) Consilience and rigour - commentary by Andre Green (Paris). NeuroPsychoanalysis - an interdisciplinary journal for psychoanalysis and the neurosciences International Universities Press, vol1(01):40-44

Green A (2003). André Green e a fundação Squiggle/[editor] Jan Abram; [tradução Magda Lopes; revisão científica Celina Giacomelli]. São Paulo: Roca.

Grotstein JS (2003). Quem é o sonhador que sonha o sonho? - um estudo de presenças psíquicas/James S. Grtstein; tradução: Sérgio MT. Trunci [et al.]; com um prólogo por Thomas Ogden. Rio de Janeiro: Imago.

Grotstein JS (2005). 'Projective transidentification': An extension of the concept of projective identification Int J Psychoanal 2005;86:1051-69.

HaCohen R (2001). The Music of Sympathy in the Arts of the Baroque; or, the Use of Difference to Overcome Indifference Poetics Today 22(3):607-650

Hartmann H (1962). La psicologia del yo y el problema de la adaptacion. México: Editorial Pax-Mexico, S.A.

Heilman K H, Valenstein E (1985). Clinical Neuropsychology. New York: Oxford University Press.

Herzog R, Mello R (2009). Trauma, clivagem e anestesia: uma perspectiva ferencziana Arquivos Brasileiros de Psicologia, vol. 61, n. 3. Retirado do World Wide Web http://www.psicologia.ufrj.br/abp/ 68 197-208.

Hilshelwood RD (1992). Dicionário do pensamento Kleiniano. Porto Alegre: Artes Médicas.

Huot H (1991). O Sonho e o Verbo: "A Interpretação dos Sonhos". In: Freud. Do sujeito à imagem: uma história do olho. São Paulo: Escuta p. 113-121

Hume D (1932). Treatise of Nature in E. A. Burtt, The Metaphysical Foundations of 
Modern Science. New York: Doubleday Anchor Book, pp. 231-234.

Husserl Edmund (1980). Investigações lógicas: sexta investigação: elementos de uma elucidação fenomenológica do conhecimento / Edmund Husserl; seleção e tradução de Zeljko Lopari'c e Andréa Maria Altino de Campos Loparíc. São Paulo: Abril Cultural.

Iacoboni M, Molnar-Szakacs I, Gallese V, Buccino G, Mazziotta JC, Rizzolatti G (2005). Grasping the intentions of the others with one's own mirror neuron system. Plos Biology 3(3): 529-535.

Izard CE (1977). Human emotions. New York: Plenum.

Jackson PL, Meltzoff AN, Decet J (2005). How do we perceive the pain of others? A window into the neural processes involved in empathy Neuroimage; $1 ; 24(3)$ : 771-779.

Jaspers K (1993). Psicopatología General. Colección de psicologia; psiquiatrá Y psicoanálisis - México: Fundo de Cultura Econômica.

Johnson JA, Cheek JM, Smither R (1983). The Structure of Empathy. Journal of Personality and Social Psychology. Vol. 45, No. 6, 1299-1312.

Johnson SC, Baxter L, Wilder L, Heiserman J, Pipe J, Prigatano G (2002). Neural correlates of self reflection. Brain 125:1808-1814.

Johnson MH, Griffin R, Csibra G, Halit H, Faroni T, Haan M, Tucker LA, Cohen SB, Richards (2005). The emergence of the social brain network: Evidence from typical and atypical development: J Dev Psychopathol. 17(3): 599-619.

Junqueira F, LCU (2008). A “disputa" entre Beckett e Bion: a "experimentação" do insight no resplendor da obscuridade Revista Brasileira de Psicanálise • Vol. 42, n. 2, 103117.

Kaplan-Solms K, Solms M (2005). Estudos clínicos em neuro- psicanálise. Trad. Por Beatriz Tchernin Zimerman; revisão científica e apresentação da edição brasileira de Maria Sonia Goergen; $1^{\text {a }}$ edição traduzida. São Paulo: Lemos Editorial.

Kernberg OF (1975). Borderline Conditions and Pathological Narcissism. USA: Jason Aroson, Inc.

Klein M (1991). Inveja e gratidão e outros trabalhos (1946-1963). Melanie Klein: tradução da 4a edição inglesa; Elias Mallet da Rocha, Liana Pinto Chaves (coordenadores) e colaboradores. - Rio de Janeiro: Imago.

(1952) Algumas conclusões teóricas relativas à vida emocional do bebê.

(1946) Notas sobre alguns mecanismos esquizóides

(1959) Nosso mundo adulto e suas raízes na infância 
Lacan J (1995). Seminário livro 4 - A relação de objeto 1956-1957. Rio de Janeiro: Jorge Zahar Editor Ltda.

Lamm C, Nusbaum HC, Meltzoff AN (2007b). What are you feeling? Using functional magnetic resonance imaging to assess the modulation of sensory and affective responses during empathy for pain. PLOS ONE, 12, e 1292.

La Taille Y (2006). A Importância da Generosidade no Início da Gênese da Moralidade na Criança, Psicologia: Reflexão \& Crítica, 19(1): 09-17.

LeDoux J (1996). O cérebro emocional: os misteriosos alicerces da vida emocional, Rio de Janeiro: Objetiva Ltda.

Levinas E (2008). De Deus que vem à idéia. Petrópolis, RJ: Vozes.

Levinas E (2009). Entre nós: ensaios sobre a alteridade. Petrópolis, RJ: Vozes.

Lévinas E (1990). Autrement qu'Être ou au-delà de l'Essence, Paris, Kluwer Academic.

Meltzoff AN (2005). Imitation and other minds: the 'like me' hypothesis. From:

Hurley S and Chater N (eds) Perspectives on imitation: from neuroscience to social science vol.2 p.55-77 Cambridge MA, MIT Press.

Merea CE (1994). Os conceitos de objeto na obra de Freud. In: W. Baranger e colaboradores Del Campo, Goldstein, Mera, Mom, Resnicoff, Ricón, Romano, Schutt Contribuições ao conceito de Objeto em Psicanálise. São Paulo: Casa do Psicólogo: Clínica de Psicanálise Roberto Azevedo p.1-15

Merleau-Ponty M (1994). Fenomenologia da percepção. São Paulo: Martins Fontes.

Mesulan MM (1993). Behavioral Anatomy of the limbic System. Behavioral Neurology: limbic system in neurology and psychiatry - American Academy of Neurology, 246-1.

(2000) Principles of behavioral and cognitive neurology. 2ed., U.K: Oxford University Press.

Mezan R (2001). Freud: a trama dos conceitos. 4a edição. São Paulo: Ed. Perspectiva.

Mezan R (1997). Figura e fundo: notas sobre o campo psicanalítico no Brasil. Percurso.

Montang C, Gallinat J, Heinz A (2008). Theodor Lipps and the Concept of Empathy: 1851-1914 Images in psychiatry, Am J Psychiatry 165:10.

Morin, E. (1999) Ciência com consciência. Rio de Janeiro: Bertrand Brasil.

Nezlek JB, Feist GJ, Wilson FC, Plesko R M (2001). Day-to-Day Variability in Empathy as a Function of Daily Events and Mood. Journal of Research in Personality 35: 401-423. 
Nishitani N (2006). Biological significance of Broca's region. Rinsho Shinkeigaku. 46(11): 851-3.

Ogden TH (1996). Reconsiderando três aspectos da técnica psicanalítica. Artigo publicado originalmente no Int. J. Psychoan.,tradução: Bernardo Tanis, revisão de Luís Cláudio Figueiredo e Elisa Ulho Cintra.

Ogden TH (2003). What's true and whose idea was it. Int J Psychoanal 84:593-606.

Phillips ML, Young AW, Senior C, Brammer M, Andrew C, Calder AJ, Bullmore ET, Perrett DI, Rowland D, Williams SC, Gray JA, David AS (1997). A specific neural substrate for perceiving facial expressions of disgust. Nature 89:49-498.

Pimentel AKP, Coelho Jr N (2009). Algumas Considerações sobre o uso da empatia em casos e situações limite. Psicologia Clínica. Rio de Janeiro, Vol.21, N.2, p.301- 314.

Pincus JH, Tucker GJ (1985). Behavioral Neurology. New York: Oxford University Press.

Platão (1983). Sofista. In: Diálogos. São Paulo: Abril Cultural, Coleção Os pensadores.

Pontius AA (1989). Subtipes of limbic sistem dysfunction evoking homicide in limbic pychotic trigger reaction and temporal lobe epilepsy - evolutionary constraints. Psychological Reports 65: 659-671.

Plotino (2008). Enéada III. 8 [30]: sobre a natureza, a contemplação e o Uno. Campinas, SP: Editora da Unicamp.

Plutchik R (1994). The Psychology and Biology of emotion. New York: HarperCollins College Publishers.

Porchat P (2005). Freud e o teste de realidade. São Paulo: Casa do Psicólogo: FAPESP.

Premack D, Wodruff G (1978). Does the chimpanzee have a theory of mind? Behavioral and Brain Sciences 1: 515-526.

Pribram KH, Gill MM (1976). Freud's "Project" re-assessed: Preface to contemporary cognitive theory and neuropsychology. New York: Basic Books.

Prigogine I e Stengers I (1992). Entre o tempo e a eternidade. São Paulo: Companhia das Letras.

Quintana J, Davidson T, Kovalik E, Stephen RM, Mazziotta JC (2001). Compensatory Mirror Cortical Mechanism for Facial Affect Processing in Schizophrenia. Neuropsychopharmacology 25(6): 915-924.

Roudinesco E, Plon M (1998). Dicionário Psicanálise, tradução Vera Ribeiro e Lucy Magalhães, RJ: Jorge Zahar Ed. 
Sacks 0 (1995). Um antropólogo em marte: sete histórias paradoxais. São Paulo: Companhia das Letras.

Sandler PC (2000). A apreensão da realidade psíquica. Vol 2: os primórdios do movimento romântico e a psicanálise / Paulo César Sandler. Rio de Janeiro: Imago. 108 p. (2003) 0 projeto científico de Freud em perigo, um século depois? Um estudo psicanalítico e epistemológico. In: Green, A. Psicanálise contemporânea. Revista francesa de Psicanálise. Número especial, 2001/coordenação de tradução Paulo César Sandler - Rio de Janeiro: Imago; São Paulo: SPBSP. Depto de publicações.

Segal H (1975). Introdução `a obra de Melanie Klein. Imago Editora LTDA: Rio de Janeiro, RJ.

Schacter DL (1992). Implicit knowledge: New perspectives on unconscious processes. Proc. Nati. Acad. Sci. USA Vol. 89, pp. 11113-11117.

Schopenhauer A (2004). Metafísica do amor, metafísica da morte. São Paulo: Martins Fontes.

Schopenhauer A (2001). Sobre o fundamento da moral. São Paulo: Martins Fontes.

Schore AN (1994). Affect Regulation and the origin of the self - the neurobiology of emotional development. UK: Lawrence Erlbaum associates .

(1997) A century after Freud's project: is a rapprochement between psychoanalysis and neurobiology at hand? J Am Psychoanal Assoc 45(3):807-40.

(2003) Affect Regulation and repair of the self . $1^{\text {st }}$ ed. New York, London: W.W. Norton \& Company.

Shevrin H, Brakel AWL (2005). Anxiety, attributional thinking, and the primary process. Int J Psychoanal 86:1679-93.

Silva NJ (1998/1999). A Propósito da Introdução à Crítica da Razão Pura Revista Eletrônica Print by http://www.funrei.br/revistas/filosofia.

Simone AD (2003). Estudo da memória operacional verbal em pessoas saudáveis através da ressonância magnética funcional relacionada a eventos. (não publicada), Instituto de Psicologia da Universidade de São Paulo, São Paulo.

Singer T, Seymour B, O’Doherty J, Kaube H, Dolan RJ , Frith CD Empathy for Pain Involves the Affective but not Sensory Components of Pain Science Vol. 303 p. 1157-1162.

Singer T, Vignemont F (2006). The empathic brain: how, when and why? and Trends in Cognitive Sciences, Vol. 10. 
Slipp S (2000). Subliminal stimulation research and its implications for psychoanalytic theory and treatment. J Am Acad Psychoanal 28(2):305-20.

Solms M, Neserssiam E (1999). Editorial of Neuro-psychoanalysis - an interdisciplinary journal of psychoanalysis and the neurosciences 1(1):3-4.

Solms M, Turnbull O (2002). The brain and the inner world: an introduction to the neuroscience of subjective experience. New York: Other Press.

Stein DJ (1997).Cognitive Science and the unconscious/ edited by Dan. J. Stein. $1^{\text {st }}$ ed. Washington: American Psychiatric Press, Inc.

Stephan KE (2004). On the role of general system theory for functional neuroimaging. J Anat 205:443-470.

Tebartz van Elst, L. et al (2003). Frontolimbic brain abnormalities in patients with borderline personality disorder: a volumetric magnetic resonance imaging study. Biol Psychiatry 54:163-171.

Tomkins SS, McCarter R (1964). 0 que são e onde estão os sentimentos primários? Algumas evidências para uma teoria. Perceptual and Motor Skills 18:119-58.

Holmes OW (2007). Descartes, Hume, Kant and Diderot: The interconnectedness of the Self and Nature. In: Tymieniecka A. Phenomenology of life from the animal soul to the human mind. Book II The Human Soul in the Creative Transformation of the Mind, pp. 381417. The Netherlands: Springer

Vollm BA (2006). Neural correlates of theory of mind and empathy: a functional magnetic resonance imaging study in a nonverbal task. Neuroimage 29:90-98.

Wicker B, Keysers C, Plailly J, Royet JP, Gallese V, Rizzolatti G (2003). Both of us disgusted in my insula: the common neural basis of seeing and feeling disgust. Neuron 40:655-664.

Williams JHG, Waiter GD, Gilchrist A, Perrett D, Murray AD, Whiten A (2006). Neural mechanisms of imitation and 'mirror neuron' functioning in autistic spectrum disorder. Neuropsychologia 44:610-621.

Merea CE (1994). Os conceitos de objeto na obra de Freud. In: Baranger e col. Contribuições ao conceito de objeto em psicanálise. São Paulo: Casa do Psicólogo: Clínica de Psicanálise Roberto Azevedo 01:01-15.

Winnicott DW (1990). Natureza humana; tradução de David Litman Bogomoletz. Rio de Janeiro: Imago. 
(1971) Mirror-role of mother and family in child development. In: Playing and reality, p. 111-8. London: Tavistock.

Winnicott D W (1983). O ambiente e os processos de maturação - estudos sobre a teoria do desenvolvimento emocional. Porto Alegre: Artes Médicas.

Winnicott D W (1960). Distorção do ego em termos de falso e verdadeiro "self". In: 0 ambiente e os processos de maturação: estudos sobre a teoria do desenvolvimento emocional. Porto Alegre: Artes Médicas, 1983.

Zajonc R (1980). American Psychologist 35, p.151-175.

Zamora JM (2003). Entre la academia y el pórtico: La sympátheia en Plotino Revista latinoamericana de filosofía vol. 29 (1): pp. 97-121.

Zimerman, David E (2004). Bion: teoria à prática - uma leitura didática / David E. Zimerman. - 2.ed. - Porto Alegre: Artmed.

\section{Dicionários}

Collins German Dictionary, complete \& unabridged, 5th edition 2004, (C) William Collins Sons \& Co. Ltd. , 1980 (C) HarperCollins Publishers 1991, 1997, 1999, 2004"

Websters 1828 Dictionary empathy. (n.d.). Dictionary.com Unabridged. Retrieved February 01, 2010, from Dictionary.com website:

http://dictionary.reference.com/browse/empathy

Websters 1828 Dictionary

sympathy. Dictionary.com. Dictionary.com Unabridged. Random House, Inc.

http://dictionary.reference.com/browse/sympathy (accessed: February 01, 2010).

Collins Thesaurus of the English Language - Complete and Unabridged 2nd Edition. 2002 (C) HarperCollins Publishers 1995, 2002 http://www.thefreedictionary.com/

Fachwörterbuch Medizin: Deutsch-Englisch, Volume 2 